Prosperidad parattodos

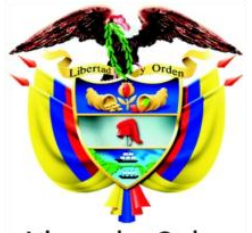

Libertad y Orden

Ministerio de la Protección Social

República de Colombia

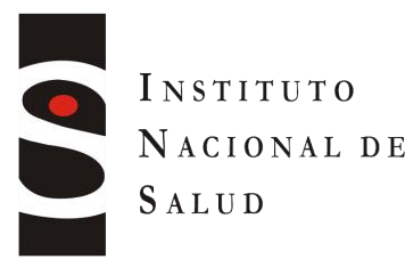

\title{
IDENTIFICACIÓN DE RIESGOS BIOLÓGICOS ASOCIADOS AL CONSUMO DE LECHE CRUDA BOVINA EN COLOMBIA
}

CONTRATO 081 DE 2010

República de Colombia

Instituto Nacional de Salud

Subdirección de Investigación 


\section{IDENTIFICACIÓN DE RIESGOS BIOLÓGICOS ASOCIADOS AL CONSUMO DE LECHE CRUDA BOVINA EN COLOMBIA}

Ministerio de Salud y Protección Social

Unidad de Evaluación de Riesgos para la Inocuidad de los Alimentos UERIA

Instituto Nacional de Salud INS

2011

Bogotá D.C., 2011

Impresión: Imprenta Nacional de Colombia

(CQueda prohibida la reproducción parcial o total de este documento, por cualquier medio escrito o visual, sin previa autorización del Instituto Nacional de Salud.

Interventoría:

Sandra Liliana Fuentes Rueda - Ernesto Moreno Naranjo

Interventores Contrato interadministrativo 081-2010 MPS - INS

ISBN: 978-958-13-0151-5 


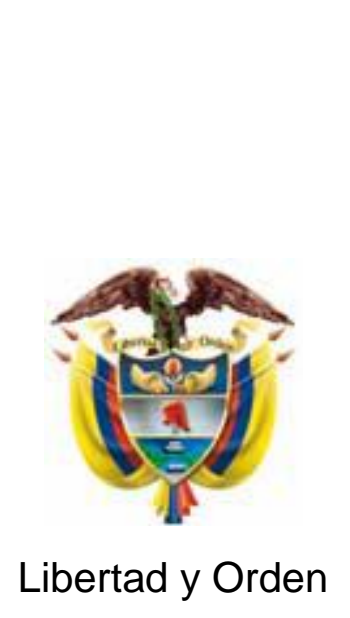

MAURICIO SANTAMARÍA SALAMANCA

Ministro de Salud y Protección Social

JAVIER HUMBERTO GAMBOA BENAVIDES

Viceministro Técnico

BEATRIZ LONDOÑO SOTO

Viceministra de Salud

RICARDO ANDRÉS ECHEVERRI

Viceministro Laboral

GERARDO LUBÍN BURGOS BERNAL

Secretario General

LENIS ENRIQUE URQUIJO VELÁSQUEZ

Director General de Salud Pública

OFICINA ASESORA DE COMUNICACIONES 


\section{JUAN GONZALO LÓPEZ CASAS \\ Director General Instituto Nacional de Salud \\ EDITH OLIVERA MARTINEZ \\ Secretaria General \\ LUIS ALBERTO GÓMEZ GROSSO \\ Subdirector de Investigación \\ DIANA XIMENA CORREA LIZARAZO \\ Coordinadora Unidad de Evaluación de Riesgos para \\ la Inocuidad de los Alimentos \\ OFICINA DE COMUNICACIONES INS}
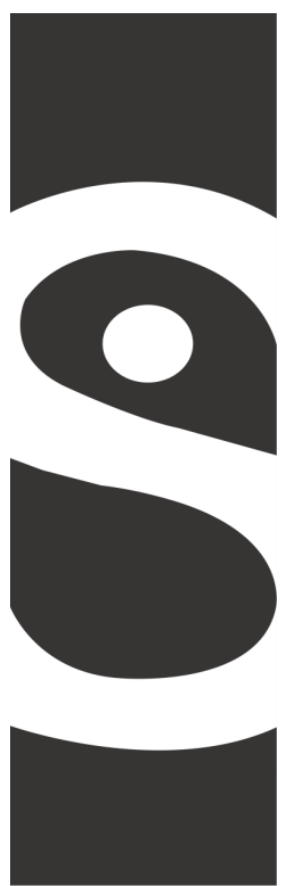

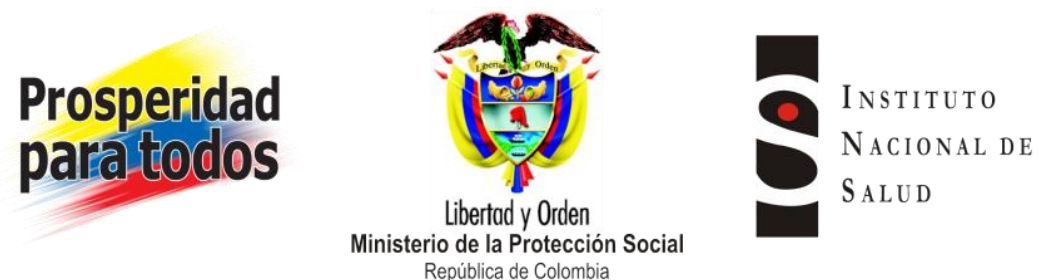

\section{GRUPO DE REDACCIÓN}

(por orden alfabético)

Natalia Milena ACOSTA AMADOR

Microbióloga, Especialista en Epidemiología

Alfonso CALDERÓN RANGEL

Médico veterinario Zootecnista, MSc. en Ciencias de la Salud Animal

Mónica Sofía CORTES MUÑOZ

Bacterióloga y Laboratorista Clínico

Diana Ximena CORREA LIZARAZO

Ingeniero de Alimentos, MSc. en Ciencia de los Alimentos

Alba Manuela DURANGO VILLADIEGO

Bacteriólogo, Magister en Microbiología, Doctor en Ciencia y Tecnología de los Alimentos

Yuly Andrea GAMBOA MARÍN

Bacterióloga y Laboratorista Clínico

Jazmín Mercedes MANTILLA PULIDO

Médico Veterinario, MSc. en Salud Animal

Nadenka Beatriz MELO BRITO

Microbióloga, MSc. en Ciencias área Microbiología

María Pilar MONTOYA GUEVARA

Microbióloga Agrícola y Veterinaria

Nubia del Pilar SARMIENTO TORRES

Microbióloga con énfasis en alimentos, Especialista en Protección de Alimentos

John Alexander VÁSQUEZ CASALLAS

Zootecnista 


\section{REVISORES CIENTÍFICOS}

Revisores Internacionales:

Günter Klein, Dipl. ECVPH Institut für Lebensmittelqualität und -sicherheit, Zentrum für Lebensmittelwissenschaften, Stiftung Tierärztliche Hochschule Hannover, Bischofsholer Damm 15, 30173 Hannover

Antonio MARTínEZ LÓPEZ Biólogo, Msc. Ciencia y Tecnología de los Alimentos, PhD. Biología.

Fernando SAMPEDRO PARRA Licenciado en Ciencia y Tecnología de Alimentos, Ph.D en Tecnología de Alimentos. 


\section{REMISIÓN DE OBSERVACIONES}

Asociación Nacional de Empresarios de Colombia (ANDI) - Cámara de la Industria de Alimentos.

Eva ACOSTA - Instituto Nacional de Vigilancia de Medicamentos y Alimentos - INVIMA.

Andrea Carolina AGUIRRE RODRÍGUEZ - International Life Sciences Institute (ILSI) Norandino

Alexander BARBOSA LEGUIZAMÓN - INSTITUTO COLOMBIANO AGROPECUARIO (ICA)

Ana Karina CARRASCAL - Pontificia Universidad Javeriana.

Bernardo CLAVIJO D - Alpina Productos Alimenticios S.A.

Cristian Camilo DíAZ - Instituto Nacional de Vigilancia de Medicamentos y Alimentos INVIMA.

Juan Fernando GALLEGO BELTRÁN - Secretaría Técnica de la Comisión Intersectorial de Medidas Sanitarias y Fitosanitarias, Departamento Nacional de Planeación (DNP)

Bernadette KLOTZ CEBERIO - Universidad de la Sabana.

Julián Paul MARTINEZ GALAN - Universidad de Antioquia.

Claudia Patricia MORENO B - Ministerio de la Protección Social

Nestlé de Colombia.

Francisco Javier OSORIO MARTINEZ - INSTITUTO COLOMBIANO AGROPECUARIO (ICA)

Nubia Pilar SARMIENTO TORRES - Universidad de Pamplona.

Reinaldo VÁSQUEZ A - Federación Colombiana Cooperativas De Productores De Leche (FEDECOLECHE). 


\section{ÍNDICE}

1. JUSTIFICACIÓN, ALCANCE, OBJETIVO Y TÉRMINOS DE REFERENCIA 14 JUSTIFICACIÓN DEL MINISTERIO DE LA PROTECCIÓN SOCIAL 14

2. INTRODUCCIÓN 16

3. IDENTIFICACIÓN DEL PELIGRO 18

3.1 PREVALENCIA DE PATÓGENOS EN LECHE CRUDA DE BOVINOS 18

$\begin{array}{lll}3.1 .1 & \text { En el contexto internacional } & 18\end{array}$

3.1.2 En Colombia 21

3.2 BROTES DE INTOXICACIÓN E INFECCIÓN ALIMENTARIA POR CONSUMO DE LECHE CRUDA 24

3.2.1 En el contexto internacional 24

3.2.2 Brotes en Colombia 28

3.3 CARATERÍSTICAS Y MÉTODOS DE DETECCIÒN DE LOS MICROORGANISMOS PATÓGENOS ENCONTRADOS EN LECHE CRUDA 29

$\begin{array}{lll}\text { 3.3.1 Bacillus cereus } & 29\end{array}$

$\begin{array}{lll}3.3 .2 & \text { Brucella spp. } & 29\end{array}$

$\begin{array}{lll}\text { 3.3.3 Campylobacter spp. } & 29\end{array}$

3.3.4 Coxiella burnetii 30

$\begin{array}{lll}\text { 3.3.5 Escherichia coli patógenas } & 30\end{array}$

$\begin{array}{ll}\text { 3.3.6 Listeria monocytogenes } & 31\end{array}$

3.3.7 Mycobacterium bovis 32

3.3.8 Salmonella spp. 32

3.3.9 Staphylococcus aureus enterotoxigénico 33

3.3.10 Yersinia enterocolitica 33

4. CARACTERIZACIÓN DEL PELIGRO 35

4.1 Bacillus cereus 35

$\begin{array}{ll}4.2 \text { Brucella spp. } & 37\end{array}$

4.3 Campylobacter jejuni $\quad 38$

4.4 Coxiella burnetii $\quad 40$

4.5 Escherichia coli enterohemorrágica O157:H7 41

4.6 Listeria monocytogenes 42

4.7 Mycobacterium bovis $\quad 44$ 
4.8 Salmonella spp. $\quad 45$

4.9 Staphylococcus aureus enterotoxigénico 46

4.10 Yersinia enterocolitica 48

5. EVALUACIÓN DE LA EXPOSICIÓN 50

5.1 ECOLOGÍA DE LOS MICROORGANISMOS PATÓGENOS ENCONTRADOS EN LECHE CRUDA 50

5.1.1 Bacillus cereus

5.1.2 Brucella spp.

5.1.3 Campylobacter spp.

5.1.4 Coxiella burnetii

5.1.5 Escherichia coli patógenas 52

5.1.6 Listeria monocytogenes 52

5.1.7 Mycobacterium bovis. $\quad 53$

5.1.8 Salmonella spp. 53

5.1.9 Staphylococcus aureus enterotoxigénico 53

5.1.10 Yersinia enterocolitica $\quad 54$

5.2 CADENA DE PRODUCCIÓN DE LA LECHE CRUDA

5.2.1 PRODUCCIÓN LECHERA EN COLOMBIA 55

5.2.2 FUENTES DE CONTAMINACIÓN EN LA PRODUCCIÓN DE LECHE CRUDA PARA CONSUMO HUMANO DIRECTO

6. CONCLUSIONES 68

7. RECOMENDACIÓNES 72

8. GLOSARIO 75

9. SIGLAS 78

10. AGRADECIMIENTOS

11. BIBLIOGRAFÍA $\quad 80$

12. ANEXOS 101 


\section{ÍNDICE DE TABLAS}

Tabla 1. Presencia de microorganismos patógenos reportados internacionalmente ...........................19

Tabla 2. Prevalencia de algunos microorganismos patógenos reportados en Colombia .......................21

Tabla 3. Algunos brotes reportados internacionalmente por el consumo de leche entre 1999 y $2010 \ldots 26$

Tabla 4. Brotes reportados al SIVIGILA asociados al consumo de leche periodo 2007- 2010.............28

Tabla 5. Clasificación de la especie entérica de Salmonella .............................................................. 32

Tabla 6. Resumen de los límites de crecimiento y sobrevivencia de los microorganismos patógenos asociados a brotes por consumo de leche cruda............................................................................. 50

Tabla 7. Parámetros para la producción de la toxina estafilocócica ..................................................54

Tabla 8. Aislamiento de patógenos en cuatro (4) granjas lecheras de Estados Unidos. ......................57 


\section{ÍNDICE DE FIGURAS}

Figura 1 Producción primaria de la leche y algunas de las vías de comercialización de la leche cruda

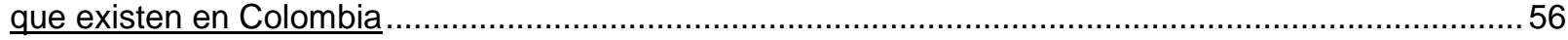




\section{ÍNDICE DE ANEXOS}

Anexo 1. Medidas de Control y Requisitos de Algunos Países para la Comercialización de Leche Cruda para Consumo Humano …..................................................................................................... 101

Anexo 2. Breve Reseña de los aspectos sociales y culturales del consumo de leche cruda ............... 110 


\section{JUSTIFICACIÓN, ALCANCE, OBJETIVO Y TÉRMINOS DE REFERENCIA}

\section{JUSTIFICACIÓN DEL MINISTERIO DE LA PROTECCIÓN SOCIAL ${ }^{1}$}

La leche de vaca es un alimento cuya composición varía en función de la raza, alimentación, edad, período de lactación, época del año y sistema de ordeño, entre otros factores. Su principal componente es el agua, seguido por grasa, proteínas e hidratos de carbono. Además contiene, moderadas cantidades de vitaminas (A, D, y vitaminas del complejo B, especialmente B2, B1, B6 y B12) y minerales (fósforo, calcio, zinc y magnesio). Por todo lo anterior, éste es un alimento con un alto valor nutricional.

En 2010 el Instituto Colombiano de Bienestar Familiar (ICBF) (1) reportó que un 48,7\% de los colombianos entre 5 y 64 años de edad consumen diariamente leche líquida, siendo éste uno de los productos más importantes en la canasta familiar. La obtención de la leche cruda está reglamentada por el Decreto 616 de 2006 y los requisitos de comercialización en el territorio nacional para consumo humano directo están estipulados por el Decreto 1880 del 27 de mayo de $2011(2,3)$.

El mercado de la leche cruda en Colombia es objeto de regulación por parte del Estado, debido a que este producto es uno de los de mayor impacto en salud pública por ser un alimento de alto riesgo $(3,4)$. Ello, debido a que su calidad e inocuidad, se ven comprometidas desde su ordeño hasta que llega al consumidor final por peligros biológicos y químicos. La inadecuada manipulación de la leche cruda y las malas prácticas de ordeño en la producción primaria, así como la carencia o insuficiencia de enfriamiento de la leche cruda, conlleva al crecimiento microbiano en menor tiempo, poniendo en riesgo a la población que lo consume $(2,3)$.

Dentro de los peligros más relevantes que se encuentran en la leche, se hallan/están los microorganismos patógenos, las toxinas, las sustancias químicas como pesticidas, antibióticos, metales pesados, detergentes, desinfectantes y partículas de extrañas, las cuales pueden causar alteración microbiológica y físico-química en este producto.

\footnotetext{
${ }^{1}$ El texto corresponde a la justificación entregada a la UERIA por el Gestor de Riesgos para el desarrollo de la Evaluación de Riesgos.
} 
La Organización Mundial de la Salud OMS y la Organización Panamericana de la Salud OPS- (5), establecen que asociado al consumo de leche cruda se incrementa el riesgo de adquirir enfermedades de tipo bacteriano así: Infecciones por Streptococos betahemolíticos, Campylobacteriosis, Gastroenteritis por E. coli, Brucelosis, Tuberculosis, Listeriosis y Fiebre Tifoidea y Paratifoidea, entre otras.

En Colombia, existen una serie de condiciones que favorecen el aumento y la propagación de estas enfermedades entre las cuales podemos mencionar: el crecimiento de las poblaciones humanas y animales, la creciente urbanización y explotación intensiva de animales, y la mayor frecuencia de ferias y movimientos de animales.

Nota. En reunión con el grupo de evaluación de riesgos y el gestor (Ministerio de la Protección Social- MPS), se definió que los alcances del presente documento son los peligros biológicos en leche cruda bovina para consumo humano directo de la población en general. Igualmente, se definió el siguiente objetivo: "Realizar la evaluación cualitativa de riesgos de los peligros biológicos que están presentes en leche cruda para consumo directo y que pueden afectar la salud de los consumidores".

\section{TÉRMINOS DE REFERENCIA}

El Ministerio de Protección Social como gestor de riesgo estableció las siguientes preguntas al panel de expertos de leche cruda:

1. ¿Cuáles son los microorganismos patógenos/toxinas que pueden encontrarse en la leche cruda y en qué dosis producen enfermedad en el consumidor?

2. ¿Cuáles son los factores/vías principales que pueden contaminar la leche con microorganismos patógenos de mayor riesgo en salud pública?

3. Generar recomendaciones y estrategias de control para reducir el riesgo procedente de los peligros biológicos. 


\section{INTRODUCCIÓN}

Según la Encuesta Nacional de la Situación Nutricional en Colombia - 2010 (ENSIN) en el país la frecuencia diaria de consumo de lácteos para la población entre 5 y 64 años es del $61 \%$; para esta misma población el consumo de leche (líquida o en polvo) corresponde al $48,7 \%$ por día; las regiones con menor consumo en este periodo fueron la Pacífica, Amazonia y Orinoquia (6). Según la ENSIN - 2005 la leche líquida ocupa entre el 5ํy el 6o lugar de los alimentos más consumidos, siendo el grupo de individuos entre 2 y 3 años los que más la consumen (310,4 g/individuo/día) (6). De acuerdo con la Encuesta Nacional Agropecuaria, en el año 2009 se produjeron diariamente 15.752 .509 litros de leche en el país, de los cuales el $81 \%$ fue vendida o comercializada así: $41 \%$ a la industria, $36 \%$ a los intermediarios y $4 \%$ a otros. Del $19 \%$ restante, $9 \%$ fue procesado en finca y el otro $10 \%$ consumido en la misma (7). Fuentes oficiales estiman que la producción de leche líquida en el país en el 2010 correspondió a 17.219.523 litros diarios (8).

Según el Decreto 616 del 2006, "la leche es el producto de la secreción mamaria normal de animales bovinos, bufalinos y caprinos lecheros sanos, obtenida mediante uno o más ordeños completos, sin ningún tipo de adición destinada al consumo en forma de leche líquida 0 a elaboración posterior". dicionalmente, el Decreto 1880 de 2011 define la leche cruda como aquella "que no ha sido sometida a ningún tipo de termización ni de higienización" $(2,3)$.

Su contenido de nutrientes y propiedades físico-químicas brindan un medio ideal para el desarrollo de microorganismos patógenos y presencia de otros contaminantes, lo cual, asociado con prácticas inadecuadas de producción y manufactura, convierten la leche cruda en un alimento que puede ser de alto riesgo (9-11), especialmente para sub-poblaciones susceptibles como mujeres embarazadas, pacientes inmunocomprometidos, niños y adultos mayores (12-14).

Cuando la leche se obtiene en condiciones higiénicas, y procede de animales sanos, contiene pocos microorganismos provenientes de la ubre y de los conductos galactóforos (15). Sin embargo, una vez extraída, ésta se puede contaminar en cada una de las etapas de la cadena productiva.

Entre los contaminantes y los factores de contaminación externa están las heces del animal, el ambiente que lo rodea, los utensilios usados durante el proceso de ordeño, los tanques de almacenamiento, el transporte y la comercialización, así como el manipulador y el agua utilizada para los procesos de lavado y desinfección en las etapas de ordeño (16). Cuando se 
ordeñan animales enfermos la leche puede venir contaminada vía endógena con microorganismos patógenos como Staphylococcus aureus, Brucella spp., Mycobacterium bovis y Coxiella burnetii, entre otros (17).

Una leche cruda inocua para el consumo humano es el resultado de buenas prácticas aplicadas a lo largo de todas las etapas del proceso, incluida la salud y las etapas de obtención, recolección, transporte y comercialización de la leche.

Según la Unidad de Seguimiento de Precios (USP) del Ministerio de Agricultura y Desarrollo Rural (MADR) el 37,65\% de las leches producidas en el primer semestre de 2009, presentaron recuentos de bacterias mesófitas aerobias mayores de $700.000 \mathrm{UFC} / \mathrm{mL}$, límite máximo permitido en la normativa vigente $(3,18,19)$, indicando que esta leche presenta una calidad inferior a la exigida.

Teniendo en cuenta lo anteriormente expuesto y reconociendo la importancia que tiene el consumo de leche cruda asociado con brotes de Enfermedad Transmitida por Alimentos (ETA) $(9,20-24)$, este documento pretende caracterizar cuáles microorganismos patógenos para el ser humano pueden estar presentes en la leche, los factores que favorecen su multiplicación y qué medidas de prevención existen para reducir el riesgo de infección o intoxicación por estos microorganismos y sus toxinas. 


\section{IDENTIFICACIÓN DEL PELIGRO}

La leche, por sus características físico-químicas y nutricionales es un medio favorable para la multiplicación de microorganismos patógenos y puede convertirse en un vehículo para la transmisión de enfermedades al hombre (25). Los microorganismos patógenos causantes de zoonosis como Brucella spp., Mycobacterium, Listeria monocytogenes y de mastitis como Staphylococcus aureus, entre otros, pueden llegar a la leche a través de la glándula mamaria, siendo eliminados en la misma, independiente de si el animal está o no mostrando signos de enfermedad durante el ordeño (24).

Así mismo, la leche cruda puede contaminarse en cualquiera de las etapas durante su obtención, almacenamiento y comercialización con microorganismos patógenos como, por ejemplo, Escherichia coli patógenas, L. monocytogenes, S. aureus, Salmonella spp., Campylobacter jejuni, Bacillus cereus y Yersinia enterocolitica (20, 24, 26-28).

En este documento se tendrán en cuenta los microorganismos ampliamente asociados a brotes por consumo de leche cruda y que cuenten con evidencia científica que los soporten.

\subsection{PREVALENCIA DE PATÓGENOS EN LECHE CRUDA DE BOVINOS}

\subsubsection{En el contexto internacional}

Numerosas investigaciones han detectado en la leche cruda la presencia de microorganismos patógenos $(20,29-32)$. En la tabla 1 se presenta la información reportada en diversos países de los diferentes microorganismos identificados en leche cruda, así como algunos aspectos importantes tales como hallazgos del estudio, lugar de muestreo y número de muestras. Se observa que los datos varían en función del microorganismo siendo más frecuente la información disponible para Salmonella spp., E. coli 0157:H7, Campylobacter spp. y S. aureus. Puede observarse que la información disponible para Brucella spp. se presenta en países en vías de desarrollo, ya que países industrializados como Australia, Nueva Zelanda, Holanda, Canadá, Noruega y el Reino Unido han sido declarados libres de Brucella spp. (33). 
Tabla 1. Presencia de microorganismos patógenos reportados internacionalmente

\begin{tabular}{|c|c|c|c|c|c|}
\hline Microor- ganismo & País & Muestras & $\begin{array}{l}\text { Prevalencia } \\
\%\end{array}$ & Hallazgos & Fuente \\
\hline \multirow[b]{2}{*}{ Bacillus cereus } & Suecia & 144 & 28,47 & $\begin{array}{l}\text { Reportaron presencia de esporas de } B \text {. cereus en muestras de leche de bovinos, y } \\
\text { asociaron su presencia con factores ambientales y de alimentación animal. }\end{array}$ & (34) \\
\hline & Holanda & 25 & 56 & $\begin{array}{l}\text { El } 56 \% \text { de las muestras presentaron niveles de esporas de } B \text {. cereus entre } 1 \times 10^{2} \mathrm{~mL} \\
\text { en leche, encontrándose el ensilaje como el factor principal de ingreso de las } \\
\text { esporas a la leche cruda. }\end{array}$ & (35) \\
\hline \multirow{3}{*}{ Brucella abortus } & \multirow{2}{*}{ Kenia } & $\begin{array}{l}\text { Hogares } \\
213 \text { (época seca) } \\
219 \text { (época lluvia) } \\
\end{array}$ & $\begin{array}{l}7,5 \\
2,3\end{array}$ & \multirow{2}{*}{$\begin{array}{l}\text { Los autores concluyeron que el almacenamiento de la leche incrementa las } \\
\text { oportunidades de exposición a } B \text {. abortus. } \\
\text { Confirmaron presencia del microorganismo por la detección de anticuerpos y la } \\
\text { relacionaron con el sistema productivo. }\end{array}$} & \multirow[b]{2}{*}{ (36) } \\
\hline & & $\begin{array}{l}\text { Comercio informal } \\
220 \text { (época seca) } \\
236 \text { (época lluvia) } \\
\end{array}$ & $\begin{array}{l}1,4 \text { a } 3,6 \\
0 \text { a } 4,1\end{array}$ & & \\
\hline & $\begin{array}{l}\text { Birmania } \\
\text { (Myanmar) }\end{array}$ & 113 & 9,73 & $\begin{array}{l}\text { Las muestras se obtuvieron de leche cruda proveniente de tanques de } \\
\text { almacenamiento. Los autores concluyeron que las explotaciones pequeñas }(<50 \\
\text { cabezas de ganado/rebaño) parecen tener una menor probabilidad de infección por } \\
\text { Brucella. }\end{array}$ & (37) \\
\hline \multirow{2}{*}{$\begin{array}{l}\text { Campylobacter } \\
\text { jejuni }\end{array}$} & EEUU & $N / d$ & 0,4 a $12,3 \%$ & $\begin{array}{l}\text { Prevalencia en muestras de leche de tanques osciló entre } 0,4 \text { y } 12,3 \% \text { e involucra } \\
\text { leche no pasteurizada o mal pasteurizada. } \\
\text { Este es un artículo de revisión que recopila información de } 7 \text { fuentes. }\end{array}$ & (20) \\
\hline & EEUU & 131 & 9,2 & $\begin{array}{l}\text { Determinaron presencia en el } 9,2 \% \text { de las muestras atribuido a presencia de heces } \\
\text { en la leche. }\end{array}$ & (38) \\
\hline \multirow[t]{3}{*}{ Coxiella burnetii } & Corea & $\begin{array}{l}\text { Bovinos: } 414 \\
\text { Humanos: } 205\end{array}$ & $\begin{array}{l}25,6 \\
1,5\end{array}$ & $\begin{array}{l}\text { La seroprevalencia fue del } 25,6 \% \text { en bovinos y del } 1,5 \% \text { en humanos. Los datos } \\
\text { sugieren que los factores ambientales pueden contribuir a la diseminación de } C \text {. } \\
\text { burnetti en bovinos. }\end{array}$ & (40) \\
\hline & EEUU & 21 & 42,9 & $\begin{array}{l}\text { La prevalencia fue del } 42,9 \% \text { en muestras de leche cruda y se confirmó que es } \\
\text { viable encontrar este patógeno si se comercializa leche cruda. }\end{array}$ & (41) \\
\hline & Dinamarca & 100 & 59 & $\begin{array}{l}\text { Se determinó la presencia de anticuerpos en } 59 \text { muestras de leche de tanque } \\
\text { extraídas de } 100 \text { hatos lecheros en ese país. }\end{array}$ & (42) \\
\hline \multirow{8}{*}{$\begin{array}{l}\text { Escherichia coli } \\
\text { O157:H7 }\end{array}$} & Turquía & 100 & 1 & $\begin{array}{l}\text { Se determinó en el 1\% de muestras. Considerando que existen portadores } \\
\text { asintomáticos, se aumenta el riesgo de trasmisión desde la producción primaria. }\end{array}$ & (43) \\
\hline & Kenia & 264 & 0,8 & Se relacionó con el consumo de leche no sometida a tratamientos térmicos. & $(36)$ \\
\hline & EEUU & NR & 0,8 a 3,8 & $\begin{array}{l}\text { Leche cruda de tanque. Este es un artículo de revisión que recopila información de } 3 \\
\text { fuentes. }\end{array}$ & (20) \\
\hline & Costa Rica & 100 & 2 & $\begin{array}{l}\text { Se atribuyó el } 2 \% \text { de las muestras positivas de leche cruda a la amplia utilización de } \\
\text { métodos manuales de ordeño. }\end{array}$ & (44) \\
\hline & Egipto & 50 & 6 & Leche sin pasteurizar de un supermercado o granja. & $\begin{array}{c}(45, \\
46)\end{array}$ \\
\hline & Canadá & 1.012 & 0,3 & Leche cruda destinada a proceso. & $(45,47)$ \\
\hline & $\begin{array}{l}\text { Inglaterra y } \\
\text { Gales }\end{array}$ & 1.097 & 0,3 & $\begin{array}{l}\text { Tres de las muestras de leche cruda fueron positivas; estas tenían un recuento } \\
\text { microbiológico satisfactorio. }\end{array}$ & $(45,49)$ \\
\hline & Inglaterra & 10 & 10 & Las muestras de leche cruda provenían de bovinos con resultado positivo en heces & $(45,50)$ \\
\hline
\end{tabular}




\begin{tabular}{|c|c|c|c|c|c|}
\hline Microor- ganismo & País & Muestras & $\begin{array}{l}\text { Prevalencia } \\
\%\end{array}$ & Hallazgos & Fuente \\
\hline & & & & e implicados en un brote. & \\
\hline & Alemania & 273 & 0,4 & Una de las muestras de leche cruda fue positiva. & $(45,51)$ \\
\hline & Francia & 205 & 21,5 & Leche cruda destinada a elaboración de quesos. & $(45,52)$ \\
\hline & $\begin{array}{l}\text { Irlanda del } \\
\text { Norte }\end{array}$ & 420 & 2,1 & Aislamientos a partir del ambiente y leche cruda. & $(53)$ \\
\hline & Reino Unido & 610 & 0,2 & Leche cruda previa pasteurización. & $(45)$ \\
\hline & EEUU & 23 & 4,3 & Leche cruda relacionada con brotes. & $(45,54)$ \\
\hline \multirow{6}{*}{$\begin{array}{l}\text { Listeria } \\
\text { monocytogenes }\end{array}$} & EEUU & 131 & 4,6 & En leche de tanques de almacenamiento en finca. & $(38)$ \\
\hline & Costa Rica & 100 & 3 & $\begin{array}{l}\text { La prevalencia obtenida de leche cruda para uso industrial, coincide con los } \\
\text { hallazgos internacionales de Italia, Nueva Zelanda y Canadá. }\end{array}$ & (44) \\
\hline & India & 2.060 & 5,1 & $\begin{array}{l}\text { Muestras de leche cruda. } \\
\text { Del total de muestras, } 139 \text { fueron positivas para Listeria y de estas, } 105 \text { fueron } \\
\text { confirmadas como L. monocytogenes. }\end{array}$ & (55) \\
\hline & Francia & 69 & 5,8 & $\begin{array}{l}\text { Se encontraron cifras similares a otras prevalencias reportadas para el mismo } \\
\text { microorganismo y otras bacterias. }\end{array}$ & $(56)$ \\
\hline & EEUU & NR & 1 a 12,6 & $\begin{array}{l}\text { La revisión realizada por los autores señala que según los } 13 \text { artículos analizados la } \\
\text { prevalencia está entre } 1,0 \text { y } 12,6 \% \text { en leche de tanque. }\end{array}$ & (20) \\
\hline & Malasia & 930 & 1,9 & $\begin{array}{l}\text { Prevalencia de } 1.9 \% \text { en muestras de leche, cifras atribuidas a la deficiencia en el } \\
\text { manejo adecuado de temperaturas de refrigeración. }\end{array}$ & (57) \\
\hline \multirow{4}{*}{ Salmonella spp. } & EEUU & NR & 11 a 20 & $\begin{array}{l}\text { Sugiere que la filtración de la leche antes de ingresar al tanque de almacenamiento } \\
\text { en la finca, puede disminuir la prevalencia de Salmonella spp. }\end{array}$ & (58) \\
\hline & EEUU & 861 & 2,6 & Leche de tanque. & $\begin{array}{l}(20, \\
38)\end{array}$ \\
\hline & EEUU & 131 & 6,1 & $\begin{array}{l}\text { Prevalencia del } 6,1 \% \text { y establece que la presencia de este patógeno en la leche } \\
\text { cruda aumenta el riesgo de su consumo y posteriores efectos sobre la salud. }\end{array}$ & $(20,38)$ \\
\hline & EEUU & $\mathrm{N} / \mathrm{d}$ & 0,2 a 8,9 & $\begin{array}{l}\text { Leche de tanque en producción de lácteos. } \\
\text { Este es un artículo de revisión que recopila información de } 8 \text { fuentes. }\end{array}$ & $(20)$ \\
\hline \multirow{2}{*}{$\begin{array}{l}\text { Staphylococcus } \\
\text { aureus }\end{array}$} & Malasia & 930 & 60,7 & $\begin{array}{l}\text { Aislado en el } 60,7 \% \text { de las muestras asociado a las técnicas de ordeño y a escasez } \\
\text { de medidas higiénicas adecuadas. }\end{array}$ & $(57)$ \\
\hline & Trinidad & 915 & 37,2 & $\begin{array}{l}\text { Es posible que exista multiplicación de las células bacterianas previa a la } \\
\text { refrigeración de la leche. }\end{array}$ & (59) \\
\hline \multirow{3}{*}{$\begin{array}{l}\text { Yersinia } \\
\text { enterocolitica }\end{array}$} & EEUU & 131 & 6,1 & $\begin{array}{l}\text { El análisis de las } 8 \text { cepas aisladas demostró que todas eran virulentas y se } \\
\text { estableció la necesidad de implementar medidas educativas a los productores de } \\
\text { leche. }\end{array}$ & (38) \\
\hline & Francia & 69 & 36 & $\begin{array}{l}\text { Se estimó la prevalencia de Y. enterocolitica en valores similares a otras bacterias } \\
\text { como Listeria spp. y Salmonella spp. en leche cruda. }\end{array}$ & (56) \\
\hline & EEUU & 292 & 15,1 & Se encontró en leche de tanque asociada a producción de lácteos. & (20) \\
\hline
\end{tabular}




\subsubsection{En Colombia}

A continuación se relacionan investigaciones que demuestran la presencia de patógenos en leche cruda en varias regiones del país.

Tabla 2. Prevalencia de algunos microorganismos patógenos reportados en Colombia

\begin{tabular}{|c|c|c|c|c|c|}
\hline $\begin{array}{l}\text { Microor- } \\
\text { ganismo }\end{array}$ & $\begin{array}{c}\text { Dpto. } \\
\text { Municipio }\end{array}$ & $\begin{array}{c}\text { Muestras } \\
\text { analizadas }\end{array}$ & $\begin{array}{c}\text { Prevalencia } \\
\%\end{array}$ & Hallazgos & Fuente \\
\hline \multirow[t]{2}{*}{ Brucella spp. } & Popayán (Cauca) & 247 & 15 & $\begin{array}{l}\text { Los autores establecieron como factores de } \\
\text { riesgo esquemas de vacunación incompleta y la } \\
\text { convivencia de bovinos con especies menores. } \\
\text { Estudio realizado en } 2006 \text {. }\end{array}$ & (60) \\
\hline & $\begin{array}{l}\text { Chicamocha } \\
\text { (Boyacá) }\end{array}$ & 19 & $\begin{array}{c}15,8 \\
\text { (incidencia) }\end{array}$ & $\begin{array}{l}\text { Se encontraron diferencias significativas en la } \\
\text { presencia de microorganismos en relación con } \\
\text { la época del año. }\end{array}$ & (61) \\
\hline Brucella abortus & $\begin{array}{l}\text { Durania (Norte de } \\
\text { Santander) }\end{array}$ & 136 & $13,23 \%$ & $\begin{array}{l}\text { Leche cruda obtenida de tres fincas. Estudio: } \\
2004 \text { al } 2005 \\
\text { Los resultados preliminares demostraron que es } \\
\text { posible usar PCR como prueba diagnóstica de } \\
\text { brucelosis en Colombia. }\end{array}$ & (62) \\
\hline \multirow{7}{*}{$\begin{array}{l}\text { L. } \\
\text { monocytogenes }\end{array}$} & Boyacá & NR & 22,2 & $\begin{array}{l}\text { Los autores referencian que la principal fuente } \\
\text { de contaminación de la leche cruda fue la } \\
\text { alimentación con ensilajes de mala calidad y } \\
\text { deficiencia en higiene de los tanques de } \\
\text { recepción de la leche. }\end{array}$ & $(65)$ \\
\hline & Boyacá & 81 & 26 & $\begin{array}{l}\text { Muestras de leches no pasteurizadas. Se } \\
\text { detectó por PCR convencional y PCR en tiempo } \\
\text { real, métodos más rápidos que los estándar. }\end{array}$ & (66) \\
\hline & NR & NR & NR & $\begin{array}{l}\text { Se encontraron los serotipos } 4 \mathrm{~b} / 4 \mathrm{~d} \text { y } 4 \mathrm{e} \text { de } L \text {. } \\
\text { monocytogenes en leche cruda. }\end{array}$ & $\begin{array}{l}(63, \\
64)\end{array}$ \\
\hline & Paipa (Boyacá) & 10 & 50 & $\begin{array}{l}\text { Leche cruda destinada a la elaboración del } \\
\text { queso "Paipa". Se encontró el patógeno en el } \\
50 \% \text { de las muestras de proveedores. En este } \\
\text { estudio capacitaron a las personas involucradas } \\
\text { en el ordeño y se tomaron muestras } \\
\text { nuevamente obteniendo los mismos resultados; } \\
\text { los autores señalan que la capacitación no tuvo } \\
\text { ningún efecto en mejorar las condiciones del } \\
\text { ordeño. }\end{array}$ & (65). \\
\hline & Pamplona (Norte & 200 & $5,5^{\star}$ & $\begin{array}{l}\text { Los autores encontraron como factores de } \\
\text { riesgo la temperatura de transporte (osciló entre } \\
25,1^{\circ} \mathrm{C} \pm 4,2^{\circ} \mathrm{C} \text { ), la alta mezcla de leches en una }\end{array}$ & (66) \\
\hline & de Santander) & 200 & $3 \%$ & $\begin{array}{l}\text { ruta (entre } 6 \text { y } 40 \text { diferentes proveedores), el tipo } \\
\text { de transporte y los largos periodos de tiempo del } \\
\text { mismo (superiores a } 4 \text { horas). }\end{array}$ & (b6) \\
\hline & $\begin{array}{l}\text { Chicamocha } \\
\text { (Boyacá) }\end{array}$ & 28 & $92,8^{*}$ & No se caracterizó la especie "monocytogenes". & (61). \\
\hline \multirow[t]{2}{*}{$\begin{array}{l}\text { Mycobacterium } \\
\text { bovis }\end{array}$} & Sabana de Bogotá & 140 & 5,72 & $\begin{array}{l}\text { Se encontró un porcentaje de co-positividad del } \\
11,1 \% \text { entre la prueba de baciloscopia de los } \\
\text { frotis de los sedimentos de leche, con respecto a } \\
\text { la prueba de inoculación en cobayos y un } \\
\text { porcentaje de co-positividad del } 12,5 \% \text { entre la } \\
\text { prueba de baciloscopia de los frotis de los } \\
\text { sedimentos de leche con respecto a la prueba } \\
\text { de aislamiento en medios de cultivo. }\end{array}$ & $(67)$ \\
\hline & Sabana de Bogotá & 200 & 2 & $\begin{array}{l}\text { Se sugiere que la PCR es una técnica más } \\
\text { específica para la detección } M \text {. bovis que la } \\
\text { prueba intradérmica de tuberculina. }\end{array}$ & $(68)$ \\
\hline $\begin{array}{l}\text { Salmonella } \\
\text { spp. }\end{array}$ & Paipa (Boyacá) & 10 & 70 & $\begin{array}{l}\text { Se encontró el patógeno en muestras de leche } \\
\text { cruda tomadas antes de la capacitación a los } \\
\text { manipuladores; sobre Buenas Prácticas de }\end{array}$ & (65) \\
\hline
\end{tabular}




\begin{tabular}{|c|c|c|c|c|c|}
\hline $\begin{array}{l}\text { Microor- } \\
\text { ganismo }\end{array}$ & $\begin{array}{c}\text { Dpto. } \\
\text { Municipio }\end{array}$ & $\begin{array}{l}\text { Muestras } \\
\text { analizadas }\end{array}$ & $\begin{array}{c}\text { Prevalencia } \\
\%\end{array}$ & Hallazgos & Fuente \\
\hline & & & & Ordeño & \\
\hline & & 10 & 60 & $\begin{array}{l}\text { Luego de la capacitación no se evidenció una } \\
\text { disminución significativa de la presencia del } \\
\text { patógeno. }\end{array}$ & \\
\hline & \multirow{2}{*}{ Sucre } & \multirow{2}{*}{179} & 4,4 & $\begin{array}{l}\text { Presencia en muestras de leche de centros de } \\
\text { acopio y plantas procesadoras en verano. }\end{array}$ & (69) \\
\hline & & & 1,8 & $\begin{array}{l}\text { En invierno se observa disminución de su } \\
\text { presencia. }\end{array}$ & \\
\hline \multirow{7}{*}{$\begin{array}{l}\text { Staphylococcus } \\
\text { aureus }\end{array}$} & $\begin{array}{l}\text { Boyacá y } \\
\text { Cundinamarca }\end{array}$ & 1.143 & 29,09 & $\begin{array}{l}\text { leche cruda obtenida de cuartos infectados con } \\
\text { mastitis subclínica y clínica en fincas } \\
\text { especializadas del altiplano cundiboyacense } \\
\text { (70). }\end{array}$ & \\
\hline & Córdoba & 329 & 87,84 & $\begin{array}{l}\text { Fue el principal gente etiológico aislado de leche } \\
\text { cruda de bovinos con mastitis clínica y } \\
\text { subclínica, en sistemas doble propósito }\end{array}$ & (71) \\
\hline & \multirow{2}{*}{$\begin{array}{l}\text { Chicamocha } \\
\text { (Boyacá) }\end{array}$} & 34 & 64,71 & \multirow{2}{*}{$\begin{array}{l}\text { Estudio realizado en leche cruda proveniente de } \\
34 \text { hatos, donde el } 41 \% \text { de las muestras se } \\
\text { encontraron superando las } 100.000 \text { UFC/mL. } \\
\text { En el segundo muestreo realizado en época de } \\
\text { lluvia y aplicando terapia de la vaca seca, solo el } \\
9,09 \% \text { superó las } 100.000 \text { UFC/mL. } \\
\text { Este estudio mostró que en época de lluvias los } \\
\text { recuentos son mayores, debido a que la } \\
\text { contaminación de las ubres de las vacas con } \\
\text { barro y estiércol y la alta humedad, facilitan una } \\
\text { mayor proliferación de los microorganismos. }\end{array}$} & \multirow[b]{2}{*}{ (61) } \\
\hline & & 33 & 66,67 & & \\
\hline & Paipa, Boyacá & 20 & 100 & $\begin{array}{l}\text { Reportan niveles de contaminación similares en } \\
\text { la leche de los proveedores y en las mezclas } \\
\text { Los recuentos variaron de } 1,3 \times 10^{2} \text { a } 1,9 \times 10^{5} \\
\text { UFC/mL, siendo esta última concentración } \\
\text { suficiente para producir la toxina }\end{array}$ & (65) \\
\hline & \multirow{2}{*}{ Sucre } & \multirow{2}{*}{179} & 94 & $\begin{array}{l}\text { Muestras de leche de centros de acopio } \\
\text { recolectadas en verano presentaron recuentos } \\
\text { superiores a } 10^{3} \mathrm{UFC} / \mathrm{mL} \text {. }\end{array}$ & \multirow{2}{*}{ (69) } \\
\hline & & & 100 & $\begin{array}{l}\text { En invierno el } 100 \% \text { de las muestras } \\
\text { presentaron recuentos superiores a } 10^{3} \\
\text { UFC } / \mathrm{mL} \text {. }\end{array}$ & \\
\hline
\end{tabular}

${ }^{*}$ Listeria spp

De la tabla anterior se puede evidenciar que los datos de los tres estudios para Brucella spp fueron similares mostrando una prevalencia entre $13,23 \%$ y $15,8 \%$ en leche cruda. En cuanto a L. monocytogenes, Vanegas y Martinez (2008), encontraron los serotipos 4b/4d y $4 \mathrm{e}$ en leche sin pasteurizar, lo cual podría indicar que en el país circula el serotipo $4 b$ responsable del $98 \%$ de los casos de listeriosis humana en el mundo $(63,64)$. En algunos estudios se concluyó que la contaminación y proliferación de microorganismos patógenos en la leche está relacionada con condiciones inadecuadas de temperatura, tipo de transporte, mezcla de leches en una ruta y largos periodos de tiempo en el transporte de la misma (superiores a 4 horas).

Por su parte, para el periodo 2000 a 2010 los Laboratorios de las Direcciones Territoriales de Salud (DTS) de Cundinamarca, Distrito Capital, Santander, Nariño, Quindío y Risaralda realizaron análisis a 2400 muestras de leche cruda en comercialización. Los datos suministrados a la UERIA por dichos laboratorios, indican que del total de muestras 
analizadas sólo al $0,25 \%(6 / 2.400)$ se les realizó análisis para la detección de $L$. monocytogenes y Salmonella spp, reportando ausencia de estos microorganismos en las mismas. Con respecto a $S$. aureus, solo el 0,29\% (7/2.400) de las muestras fueron analizadas para este patógeno, encontrándose 4 con recuentos menores a $10^{2} \mathrm{UFC} / \mathrm{mL}$ (1 de comercialización, 3 de vivienda) y las 3 restantes (ventas ambulantes) presentaron recuentos de $4,8 \times 10^{3}, 8,7 \times 10^{3}$ y $8,9 \times 10^{3} \mathrm{UFC} / \mathrm{mL}$ respectivamente. (72).

Es importante resaltar que en este documento, en el contexto nacional, no se mencionan algunos de los microorganismos patógenos referenciados internacionalmente como $E$. coli 0157:H7, E. coli enterotoxigénico (ETEC-ST), B. cereus, Y. enterocolitica y C. jejuni identificados en leche cruda, debido a que en Colombia no se encontró información disponible. 


\subsection{BROTES DE INTOXICACIÓN E INFECCIÓN ALIMENTARIA POR CONSUMO DE LECHE CRUDA}

\subsubsection{En el contexto internacional}

Mundialmente, el consumo de leche cruda ha estado asociado a brotes de intoxicación e infección alimentaria (73-75). El país que presenta considerable información sobre los brotes reportados es Estados Unidos. Una recopilación reciente estableció que en el período comprendido entre 1990-2006, se presentaron 83 brotes asociados al consumo de leche líquida de los cuales 37 estaban asociados con leche pasteurizada y 46 con leche no pasteurizada; los microorganismos más frecuentemente aislados fueron: Campylobacter spp., E. coli patógenas y Salmonella spp.; de esta información es interesante observar que estos brotes se dan principalmente en hogares y granjas (76). El Centro de Control de Enfermedades (CDC) reportó que durante el período de 1973 a 1992 ocurrieron 46 brotes asociados al consumo de leche cruda en 21 estados de los EEUU, que implicaron 1.733 casos, en los cuales los microorganismos más frecuentemente aislados fueron Campylobacter spp. (57\%) y Salmonella spp. (26\%). El 83\% (38/46) de los brotes ocurrieron antes de 1987, fecha a partir de la cual la Agencia de Medicamentos y Alimentos de los EEUU (FDA) implementó la prohibición de la venta interestatal de leche cruda. En total el 87\% (40/46) ocurrieron en estados donde la venta de leche cruda interestatal era legal. Los autores sugieren que la prohibición de la venta interestatal de leche cruda podría reducir el número de brotes asociados al consumo de leche cruda (73).

Con relación a Brucella spp., en los últimos 15 años en EEUU no se han reportado brotes; sin embargo, se han presentado casos esporádicos asociado al consumo de quesos importados (33) y se ha establecido que la población hispánica es la que presenta mayor riesgo de infectarse (77). En el Reino Unido, un estudio retrospectivo entre 1940 y 1958 mostró un brote de brucelosis que afectó a 17 niños, de los cuales 13 casos se asociaron con el consumo de leche cruda provenientes de hatos infectados (22)

Sobre L. monocytogenes, Lunde'n et al. (2004) (78) indican que, en Europa, el número de brotes de listeriosis en humanos asociados al consumo de leche cruda y productos lácteos elaborados a partir de la misma representa la mitad de los brotes totales. Además, afirma que algunos brotes también se pueden presentar por consumo de leche pasteurizada debido a recontaminación del producto durante los procesos industriales.

Al analizar la información disponible no se encontraron brotes por Mycobacterium bovis asociados al consumo de leche; no obstante, un estudio realizado en New York, Estados Unidos, identificó 35 casos de infecciones en humanos por M. bovis entre el 2001 y el 2004; casi todos los casos se presentaron en adultos inmigrantes o en niños con padres oriundos de 
México donde se identificó como posible causa del problema un queso fresco elaborado con leche sin pasteurizar proveniente de México (79). Algunos autores señalan que la ausencia de brotes asociados a este microorganismo se da por los periodos largos que se presentan antes de las manifestaciones clínicas de la enfermedad (79). La Unión Europea reportó 115 casos de $M$. bovis en humanos en el año 2008 (80).

En la tabla 3 se presenta una recopilación de algunos brotes reportados internacionalmente. Como puede observarse, los microorganismos frecuentemente implicados son Campylobacter spp., E. coli 0157:H7, Salmonella spp. y S. aureus coagulasa positivo. 
Tabla 3. Algunos brotes reportados internacionalmente por el consumo de leche entre 1999 y 2010

\begin{tabular}{|c|c|c|c|c|c|c|c|}
\hline Microorganismo & País (Estado) & Año & $\begin{array}{l}\text { Número } \\
\text { de casos }\end{array}$ & Efectos secundarios & Lugar & Causas probables & Fuente \\
\hline \multirow{4}{*}{ C. jejuni } & \multirow{2}{*}{ EEUU (Kansas) } & \multirow{2}{*}{2007} & 25 & NR & Iglesia y escuela & \multirow{2}{*}{$\begin{array}{l}\text { Queso elaborado a partir de } \\
\text { leche cruda }\end{array}$} & \multirow{2}{*}{ (81) } \\
\hline & & & 67 & NR & Evento comunitario & & \\
\hline & EEUU (Utah) & 2002 & 13 & NR & Evento (comida) & Leche cruda & $(82)$ \\
\hline & EEUU (Wisconsin) & 2001 & 75 & 9 hospitalizados & NR & $\begin{array}{c}\text { Leche cruda obtenida } \\
\text { directamente de una granja }\end{array}$ & (82) \\
\hline \multirow{13}{*}{$\begin{array}{l}\text { Campylobacter } \\
\text { spp. }\end{array}$} & EEUU (Michigan) & 2010 & 12 & NR & Granja & Lácteos sin pasteurizar & (83) \\
\hline & EEUU (Utah) & 2010 & 15 & NR & Granja & Leche cruda & (84) \\
\hline & EEUU (New York) & 2010 & 5 & NR & Granja & Leche cruda & (85) \\
\hline & EEUU (Pennsylvania) & 2010 & 10 & NR & Granja & Leche cruda & $(86)$ \\
\hline & EEUU (Pennsylvania) & 2009 & 6 & NR & Granja & Leche cruda & (87) \\
\hline & EEUU (Wisconsin) & 2009 & 35 & NR & Granja & Leche cruda & (88) \\
\hline & \begin{tabular}{|l} 
EEUU (Colorado) \\
\end{tabular} & 2009 & 11 & NR & Granja & Leche cruda & $(88)$ \\
\hline & EEUU (California) & 2008 & 16 & 1 Guillain-Barré & Lechería & Leche cruda & (89) \\
\hline & EEUU(Pennsylvania) & 2008 & 7 & NR & Granja & Leche cruda & $(90)$ \\
\hline & EEUU (California) & 2008 & 15 & NR & Eco-granja & Leche cruda & $(91)$ \\
\hline & EEUU (Georgia) & 2007 & 4 & NR & NR & Leche cruda & (92) \\
\hline & EEUU (Kansas) & 2007 & 19 & NR & Granja & $\begin{array}{l}\text { Leche cruda y lácteos } \\
\text { elaborados con leche cruda }\end{array}$ & (93) \\
\hline & EEUU (Washington) & 2007-2008 & 5 & NR & Granja & Leche cruda & (94) \\
\hline \multirow{2}{*}{ Campylobacter } & Holanda & 2005 & 22 & NR & Granja & Leche cruda & (95) \\
\hline & Holanda & 2005 & 16 & NR & Granja & Leche cruda & (95) \\
\hline \multirow{2}{*}{ E.coli } & EEUU (Connecticut) & 2008 & 5 & NR & Granja & Leche cruda & (96) \\
\hline & EEUU (Washington) & 2009 & 3 & NR & NR & Leche cruda & (89) \\
\hline E. coliO26 & Austria & 2005 & 2 & $\begin{array}{c}\text { Síndrome Urémico Hemolítico en } 1 \\
\text { niño y } 1 \text { niña de } 11 \text { y } 26 \text { meses } \\
\text { respectivamente }\end{array}$ & Hotel & $\begin{array}{l}\text { Leche cruda en un viaje a } \\
\text { Bulgaria }\end{array}$ & (97) \\
\hline \multirow{5}{*}{ E. coli O157:H7 } & Canadá & 2001 & 4 & Recuperaciones mayor a 10 días & NR & Leche cruda & $(9)$ \\
\hline & EEUU (Minnesota) & 2010 & 8 & NR & Granja & Lácteos sin pasteurizar & (98) \\
\hline & EEUU (Washington) & 2010 & 2 & Síndrome Urémico Hemolítico & Granja & Leche cruda & (99) \\
\hline & EEUU (California) & 2006 & 6 & Síndrome Urémico Hemolítico & Granja & Leche cruda y calostro & $(100)$ \\
\hline & $\begin{array}{l}\text { EEUU (Washington y } \\
\text { Oregon) }\end{array}$ & 2005 & 18 & Síndrome Urémico Hemolítico & Granja & Leche cruda & $(101)$ \\
\hline
\end{tabular}




\begin{tabular}{|c|c|c|c|c|c|c|c|}
\hline Microorganismo & País (Estado) & Año & $\begin{array}{l}\text { Número } \\
\text { de casos }\end{array}$ & Efectos secundarios & Lugar & Causas probables & Fuente \\
\hline $\begin{array}{c}L . \\
\text { monocytogenes }\end{array}$ & $\begin{array}{l}\text { EEUU (Carolina del } \\
\text { Norte) }\end{array}$ & 2000 & 12 & $\begin{array}{c}\text { Pacientes: } 11 \text { mujeres y } 1 \text { hombre. } \\
10 \text { embarazadas: } 5 \text { nacidos muertos, } \\
3 \text { partos prematuros y } 2 \text { recién } \\
\text { nacidos infectados }\end{array}$ & NR & $\begin{array}{l}\text { Queso casero estilo } \\
\text { mexicano elaborado con } \\
\text { leche cruda }\end{array}$ & $(102)$ \\
\hline M. bovis & Nueva Zelanda & 2006- 2007 & 1 & Hospitalización & NR & $\begin{array}{l}\text { Asociado al consumo de } \\
\text { leche cruda en la infancia }\end{array}$ & $(103)$ \\
\hline \multirow{2}{*}{$\begin{array}{l}\text { Salmonella } \\
\text { Newport }\end{array}$} & \multirow{2}{*}{ EEUU (Illinois) } & \multirow{2}{*}{$\begin{array}{l}2006 \\
2007\end{array}$} & 85 & NR & \multirow{2}{*}{ Tienda de comestibles } & \multirow{2}{*}{$\begin{array}{c}\text { Queso elaborado con leche } \\
\text { cruda }\end{array}$} & \multirow[b]{2}{*}{ (104) } \\
\hline & & & 67 & NR & & & \\
\hline \multirow{2}{*}{$\begin{array}{l}\text { Salmonella } \\
\text { Typhimurium }\end{array}$} & $\begin{array}{l}\text { EEUU (Multiestado: } \\
\text { Illinois, Indiana, Ohio y } \\
\text { Tennessee) }\end{array}$ & 2002 & 62 & NR & Granja & $\begin{array}{c}\text { Leche cruda, crema de leche, } \\
\text { mantequilla y malteada. }\end{array}$ & $(105)$ \\
\hline & EEUU (Pennsylvania) & 2007 & 2 & NR & $\begin{array}{l}\text { Industria láctea del } \\
\text { Condado de York }\end{array}$ & $\begin{array}{l}\text { Leche cruda y derivados } \\
\text { lácteos }\end{array}$ & $(106)$ \\
\hline S. aureus & Brasil (Minas de Gerais) & 1999 & 328 & NR & NR & $\begin{array}{l}\text { Leche cruda, presencia de } \\
\text { las toxinas SEA y SEB. }\end{array}$ & $(107)$ \\
\hline
\end{tabular}




\subsubsection{Brotes en Colombia}

En el Sistema Nacional de Vigilancia en Salud Pública (SIVIGILA) (108) durante el período 2008 - agosto de 2010, se reportaron 2 brotes asociados al consumo de leche (Tabla 4), donde los microorganismos involucrados fueron E. coli y Staphylococcus coagulasa positivo. En el Informe de Vigilancia de las Enfermedades Transmitidas por Alimentos de 2010 del Instituto Nacional de Salud se reportaron $147(16,5 \%)$ brotes asociados al consumo de queso de 899 brotes notificados (109) donde los microorganismos implicados fueron S. aureus, E. coli, Salmonella spp., Proteus spp., Bacillus cereus, L. monocytogenes y Shigella spp.

Tabla 4. Brotes reportados al SIVIGILA asociados al consumo de leche periodo 2007- 2010.

\begin{tabular}{c|c|c|c|c}
\hline Año & Lugar & Alimento implicado & Número de casos & Microorganismo asociado \\
\hline 2009 & Sincelejo (Sucre) & Leche & 3 & E. coli \\
2009 & Sucre (Sucre) & Leche & 3 & $\begin{array}{c}\text { Staphylococcus coagulasa } \\
\text { positivo }\end{array}$ \\
\hline
\end{tabular}

Fuente: SIVIGILA, 2010 (108)

Se cuenta con información disponible en el periodo 1996-2004, durante el cual se establecieron 635 casos asociados a B. abortus. Para el año 2009 el Laboratorio Nacional de Diagnóstico Veterinario-ICA procesó y confirmó 22 casos de brucelosis humana (110). Es importante aclarar que, en la mayoría de estos reportes, se desconoce la fuente de contagio. 


\subsection{CARATERÍSTICAS Y MÉTODOS DE DETECCIÒN DE LOS MICROORGANISMOS PATÓGENOS ENCONTRADOS EN LECHE CRUDA}

A continuación se describen la taxonomía, morfología, fisiología y métodos de detección de los microorganismos patógenos mayormente encontrados en leche cruda y que son abordados en esta evaluación de riesgos.

\subsubsection{Bacillus cereus}

B. cereus es un bacilo Gram positivo, aerobio facultativo, esporulado y ampliamente diseminado en el suelo. Pertenece a la familia Bacillaceae, taxonómicamente es un grupo ambiguo que incluye diversas especies como $B$. cereus y $B$. weihenstephanensis; $B$. mycoides y $B$. pseudomycoides $(69,112,113)$.

Para la detección y enumeración de $B$. cereus en leche, se recomienda el procedimiento estándar en placa de la FDA (2003), donde se utiliza el agar manitol-yema de huevo-polimixina. Las cajas se incuban a $30^{\circ} \mathrm{C}$ por $24 \mathrm{~h}$, luego en ellas se realiza el recuento y las colonias presuntivas son confirmadas mediante pruebas bioquímicas (114).

\subsubsection{Brucella spp.}

Brucella spp. es un microorganismo facultativo intracelular. Es un cocobacilo corto de 0,5 a 0,7 $\mu \mathrm{m}$ de diámetro y 0,6 a 1,5 $\mu \mathrm{m}$ de largo, Gram negativo, inmóvil, aerobio estricto, no capsulado, catalasa y oxidasa positivo (37). El género Brucella, pertenece al familia Brucellaceae, incluye nueve especies, siete de las cuales afectan animales terrestres: $B$. melitensis, $B$. abortus, $B$. suis, $B$. canis, $B$. ovis, $B$. neotomae y $B$. microti (115) y dos que afectan mamíferos marinos $B$. ceti y $B$. pinnipedialis (116). Las tres primeras especies son llamadas Brucellas clásicas y dentro de estas especies siete biovares son reconocidos para $B$. abortus, tres biovares para $B$. melitensis, y cinco para $B$. suis; de las otras especies no se tiene información (33). B. abortus, $B$. suis, $B$. canis, y especialmente $B$. melitensis causan infecciones en el hombre (117).

Para la detección de Brucella spp. en leches se pueden utilizar dos métodos: microbiológicos e inmunológicos (118). El protocolo utilizado para el aislamiento de Brucella spp. en leche cruda está recomendado por el Comité Conjunto FAO-OMS de Expertos en Brucelosis. La identificación y tipificación de Brucella spp. se realiza mediante métodos inmunológicos y moleculares $(62,119)$.

\subsubsection{Campylobacter spp.}


Es el género representativo de la familia Campylobacteriaceae. En la actualidad, el género Campylobacter consta de 17 especies, 4 de las cuales se han dividido adicionalmente en 8 subespecies (120). Se reconoce a $C$. jejuni y $C$. coli como las principales especies asociadas a ETA (121). Son células pequeñas, Gram negativas, de forma vibrioide o espiral con 0,2 a 0,8 $\mu \mathrm{m}$ de ancho y 0,5 a $5 \mu \mathrm{m}$ de largo; son catalasa y oxidasa positiva. Es microaerofílico (requiere para su crecimiento $\left.10 \% \quad \mathrm{CO}_{2}\right)$ pero algunas especies pueden crecer aeróbica $\mathrm{o}$ anaeróbicamente. No forma esporas y tiene una movilidad característica de rotación rápida por medio de un solo flagelo polar en uno o ambos extremos $(122,123)$.

Para el aislamiento de Campylobacter spp. en leche cruda es recomendado el método de la FDA (2001) (124). Este método necesita una etapa de pre-enriquecimiento y otra de enriquecimiento previa a la siembra en medios selectivos, con el fin de recuperar las células presentes en el alimento. Para su crecimiento en medios de cultivo, requiere de una temperatura de incubación de $42^{\circ} \mathrm{C}$ en condiciones de microaerofilía (5\% de oxígeno y $10 \%$ de dióxido de carbono) $(124,125)$. Posteriormente, se realizan pruebas bioquímicas para la confirmación de las colonias. Comercialmente existen métodos inmunológicos y genéticos para la identificación de este género.

\subsubsection{Coxiella burnetii}

Este microorganismo es un patógeno intracelular y tradicionalmente se ubica en la familia Rickettsiaceae; sin embargo, estudios filogéneticos recientes han demostrado que $C$. burnetii está más estrechamente relacionado a Legionella, y Francisella que al género Rickettsiella. Este organismo es clasificado actualmente en la familia Coxiellaceae, orden Legionallales en la subdivisión de Proteobacteria (126).

Por ser un microorganismo intracelular los métodos de detección están enfocados al diagnóstico de la zoonosis; en leches se pueden utilizar métodos inmunológicos o técnicas moleculares usando PCR (126); también se han usado líneas celulares para su crecimiento (127).

\subsubsection{Escherichia coli patógenas}

E. coli pertenece a la familia Enterobacteriaceae. Son bacilos cortos Gram negativos de $2 \mu \mathrm{m}$ de largo y $0,5 \mu \mathrm{m}$ de diámetro, catalasa positivos, oxidasa negativos y anaerobios facultativos. Este grupo concentra una diversidad de serovares y solo unos pocos son patógenos para el hombre por vía alimentaría (45). Pueden diferenciarse serológicamente con base en los antígenos somáticos $(\mathrm{O})$, flagelares $(\mathrm{H})$ y capsulares $(\mathrm{K})$. Presentan fimbrias y estructuras parecidas que desempeñan un papel importante en su patogenicidad. Las cepas de $E$. coli que causan la enfermedad diarreica son clasificadas en grupos específicos basados en su virulencia, mecanismos de patogenicidad, síntomas clínicos, y serogrupos O:H. Estas son: $E$. 
coli enteropatógena (EPEC); E. coli enterotoxigénica (ETEC); E. coli enteroinvasiva (EIEC); E. coli de adherencia difusa (DAEC); E. coli enteroagregante (EAEC) y E. coli enterohemorrágica (EHEC). Dentro de este grupo EHEC es la más importante por su impacto en salud pública, recibe sinónimos que incluyen E. coli productor de Shiga Toxina (STEC) debido a su homología cercana con la toxina Shiga del género Shigella y E. coli productor de Verotoxina (VTEC) por producir toxinas que afectan las células vero. De estas, E. coli enteropatógena (EPEC), E. coli enterotoxigénica $(E T E C)$ y $E$. coli enterohemorrágica $(E H E C)$ son las más frecuentemente involucradas en ETA $(128,129)$.

Para el aislamiento e identificación de las cepas patógenas de $E$. coli, diferentes a $E$. coli O157:H7, en leche cruda se recomiendan los métodos propuestos por la FDA (2009) (129). Para la enumeración de E. coli enterotoxigénico (ETEC), se realizan diluciones y posterior siembra en medios selectivos, Agar Mac Conkey y L - EMB (Eosina Azul de Metileno de Levine); las colonias sospechosas se someten a una caracterización bioquímica por métodos convencionales. Si los recuentos exceden de $10^{4}$, se recomienda realizar pruebas genéticas para establecer el grupo al que pertenecen (129). Para la identificación de E. coli O157:H7, se recomienda el método de PCR en tiempo real, el cual recientemente fue validado por la FDA y que mostró mejor recuperación al compararlo con el método microbiológico. Se utiliza un protocolo que consta de un enriquecimiento, posterior siembra en un medio selectivo e identificación mediante pruebas inmunológicas y moleculares (129).

\subsubsection{Listeria monocytogenes}

En la actualidad, el género Listeria pertenece a la familia Lactobacillaceae. Comprende ocho especies claramente diferenciadas: $L$. monocytogenes, L. innocua, L. welshimeri, L. seeligeri, $L$. ivanovii, L. rocourtiae, $L$. marthii $(130,131)$ y $L$. grayi, de las cuales solo se consideran patógenas $L$. monocytogenes y $L$. ivanovii. Las especies que se encuentran con mayor frecuencia en los alimentos son $L$. innocua y $L$. monocytogenes $(121,132,133)$.

L. monocytogenes es un bacilo corto con 0,4 a $0,5 \mu \mathrm{m}$ de diámetro y 0,5 a 2,0 $\mu \mathrm{m}$, de largo, Gram positivo, asporógeno, aerobio y anaerobio facultativo. Es Catalasa positiva y oxidasa negativa. Accidentalmente puede originar formas cocoides o células aisladas de $10 \mu \mathrm{m}$ de longitud. Son móviles a $25^{\circ} \mathrm{C}$ pero no a $35^{\circ} \mathrm{C}$. L. monocytogenes está subdividida en serotipos basados en los antígenos somático $(\mathrm{O})$ y flagelar $(H)$. Se han identificado 13 serotipos de $L$. monocytogenes (1/2a, 1/2b, 1/2c, 3a, 3b, 3c, 4a, 4b, 4c, 4d, 5, 6a, y 6b). A pesar de su amplia distribución en la naturaleza, solo 3 serotipos (1/2a, 1/2b y $4 b)$, se han reportado en infecciones humanas (132).

Para la detección y enumeración de $L$. monocytogenes en leche cruda se pueden utilizar el método propuesto por la FDA (134), en el cual está basada la técnica de presencia/ausencia que utiliza el INVIMA para leche y productos lácteos en Colombia (135), y el recuento en placa 
propuesto por la norma ISO 11290-2. Las primeras técnicas se basan en un enriquecimiento selectivo a partir de $25 \mathrm{~mL}$ de muestra en un caldo selectivo para Listeria spp., posterior siembra en medios selectivos y purificación de las colonias para realizar la identificación bioquímica del microorganismo. En el segundo método se realiza un recuento y las colonias sospechosas que pertenecer al género Listeria se someten a identificación bioquímica (134). Actualmente, se emplean kits de identificación rápida, así como pruebas para serotipificación e identificación de L. monocytogenes por técnicas moleculares e inmunológicas disponibles en el mercado.

\subsubsection{Mycobacterium bovis}

M. bovis es un miembro del "Complejo Mycobacterium tuberculosis" un grupo de microorganismos genéticamente similares que infectan al hombre y animales y que incluye 5 especies (M. tuberculosis, M. bovis, M. africanum, M. canetti y M. microti) (103).

Para la detección de este microorganismo en leches se han desarrollado diversos métodos moleculares debido a las dificultades en su crecimiento (136).

\subsubsection{Salmonella spp.}

Pertenece a la familia Enterobacteriaceae. Son bacilos Gram negativos, miden 0,4 a 0,6 $\mu$ m de ancho por 2 a $4 \mu \mathrm{m}$ de largo, anaerobios facultativos, asporógenos, usualmente móviles por flagelos perítricos (121). Las serovariedades de Salmonella son diferenciadas por los antígenos de superficie somático $(\mathrm{O})$ y flagelar $(\mathrm{H})(40,137)$.

La nomenclatura y clasificación taxonómica del género Salmonella ha sido tema de polémica durante décadas. La clasificación descrita a continuación sigue la propuesta por Le Minor y Popoff (1987) (138), Reeves et al. (1989) (139) y Tindall et al. (2005) (140). Actualmente, Salmonella está dividida en dos especies, S. enterica y S. bongori (141). Salmonella entérica está dividida en seis subespecies que son categorizadas por Tindall et al. (2005) (140) como se muestra en la tabla 4.

Tabla 5. Clasificación de la especie entérica de Salmonella

\begin{tabular}{ll}
\hline Nombre & Grupo \\
\hline Salmonella enterica subesp. Enterica & Subesp. I \\
Salmonella enterica subesp. Salamae & Subesp. II \\
Salmonella enterica subesp. Arizonae & Subesp IIIa \\
Salmonella enterica subesp. Diarizonae & Subesp IIIb \\
Salmonella enterica subesp. Houtenae & Subesp IV \\
Salmonella enterica subesp. Indica & Subesp VI \\
\hline Fuente: Doyle,2005 (121). &
\end{tabular}


El grupo V identificado originalmente como Salmonella subsp. bongori, ahora es reconocido como una especie separada, S. bongori. En la subespecie I (entérica), se encuentran más del $95 \%$ de los serovares que afectan a los humanos, $S$. entérica serovar Typhimurium (S. Typhimurium), S. entérica serovar Enteritidis ( $S$. Enteritidis), son las serovariedades más comunes asociadas al consumo de alimentos (142-144).

Para el aislamiento de Salmonella spp. en leche cruda se recomienda el método tradicional descrito por la FDA (2007) (145), el cual comprende un pre-enriquecimiento en medios no selectivos con el fin de recuperar las células con daño subletal, un enriquecimiento en medios selectivos que contienen sustancias inhibidoras para evitar el crecimiento de microorganismos competidores, y la siembra en medios sólidos selectivos para diferenciar las colonias de Salmonella spp. de otras enterobacterias. La confirmación de las cepas se realiza mediante pruebas bioquímicas y la identificación de los antígenos somático $(\mathrm{O})$ y flagelar $(\mathrm{H})$ utilizando sueros específicos $(135,145)$.

\subsubsection{Staphylococcus aureus enterotoxigénico}

Pertenece al género Staphylococcus y se presenta en forma de cocos Gram positivos que se dividen en más de un plano para formar racimos tridimensionales de células pequeñas. El tamaño de las células varía de 0,5 a $1,5 \mu \mathrm{m}$ de diámetro. Son anaerobios facultativos, no móviles, catalasa y coagulasa positivos. Sensible a la lisostafina y furanos y resistente a la bacitracina $(146,147)$.

Pertenece a la familia Micrococcaceae que incluye los géneros Micrococcus, Staphylococcus y Planococcus (121). Actualmente, se admite un total de 35 especies de acuerdo a su potencial para producir coagulasa. Es ubicuo en el ambiente y está presente en el aire, polvo, aguas, aguas residuales, superficies, hombre y animales (148).

Para la detección y enumeración de $S$. aureus en leche, se recomienda el procedimiento estándar en placa de la FDA (2003) (149), que utiliza el agar Baird Parker suplementado con emulsión de yema de huevo y telurito. Las cajas se incuban a $35^{\circ} \mathrm{C}$ por 24 a 48 horas, luego en ellas se realiza el recuento de colonias típicas. Las colonias de $S$. aureus se confirman mediante las pruebas de coagulasa y nucleasa termoestable, asi como la sensibilidad a la lisostafina y fermentacion de glucosa y manitol. Además de las técnicas tradicionales para la identificación y caracterización de $S$. aureus y sus toxinas, se utilizan diversas técnicas inmunológicas y moleculares (150).

\subsubsection{Yersinia enterocolitica}

Pertenece a la familia Enterobacteriaceae, género Yersinia en el cual se agrupan 11 especies. Es un bacilo Gram negativo, oxidasa negativo que fermenta la glucosa. Y. enterocolitica es una 
especie heterogénea que se puede dividir en un gran número de subgrupos según la actividad bioquímica y los antígenos $\mathrm{O}$ de los liposácaridos (151).

Para la detección de $Y$. enterocolitica se recomienda el procedimiento establecido por la FDA, el cual se basa en un preenriquecimiento en medio específico durante 10 días a $10^{\circ} \mathrm{C}$, y posteriores aislamientos en medios de cultivo específicos, las colonias características se someten a identificación bioquímica (152). 


\section{CARACTERIZACIÓN DEL PELIGRO}

En este componente, se desarrollan los efectos adversos para la salud relacionados con los microorganismos patógenos mayormente asociados al consumo de leche cruda y que son abordados en esta evaluación de riesgos.

\subsection{Bacillus cereus}

B. cereus produce dos tipos de síndromes de acuerdo con la toxina producida:

\section{Bacillus cereus (Toxina Entérica)}

Nombre de la enfermedad: Síndrome diarreico causado por enterotoxina de B. cereus (121, 151).

Período de incubación: El período de incubación identificado se estima entre 8 y 16 horas, logrando alcanzar en algunos casos hasta 24 horas (153).

Síntomas: Dentro de los síntomas de esta enfermedad se identifica dolor abdominal, tenesmo rectal, diarrea acuosa y a veces nauseas (114), pero no vómito.

Factores de Virulencia: $B$. cereus produce diferentes complejos de enterotoxinas de tipo proteico, denominadas:

- Hemolisina BL (HBL): es un complejo de proteína con tres diferentes subunidades proteicas: $B, L_{1}$ y $L_{2}$ y es sugerida como un factor primario de virulencia;

- Enterotoxina T: es termolábil, esta toxina no se ha asociado con brotes alimentarios

- Complejo enterotoxina no hemolítico (NHE), que incluye tres proteínas de 39,45 y 105 kKa.; y

- Citotoxina K $(114,151)$.

Modo de acción del microorganismo: Las células de $B$. cereus en crecimiento vegetativo en el intestino delgado producen una enterotoxina que causa la enfermedad diarreica. Aunque no es totalmente conocido el mecanismo, se sabe que luego de la ingestión de las células vegetativas o las esporas de $B$. cereus, las toxinas son sintetizadas y liberadas durante el final de la fase logarítmica del crecimiento del microorganismo dentro del huésped e interactúan con los receptores del intestino delgado. La enterotoxina rompe la membrana de las células epiteliales, sin ser completamente esclarecido el mecanismo $(121,151)$. 
Las enterotoxinas - de tipo proteico- pueden ser pre-producidas en el alimento cuando la población de $B$. cereus es como mínimo 100 veces superior a la necesaria para causar una intoxicación alimentaria (154).

Morbilidad: Existe un subregistro importante por lo que la verdadera incidencia del síndrome diarreico no está totalmente establecida (151).

Mortalidad: Existen muy pocos casos fatales causados por B. cereus, con un caso reportado atribuido a la toxina emética (155).

Grupos de riesgo: Todos los grupos de personas son susceptibles, aunque los síntomas más severos se han asociado con poblaciones sensibles, como son las personas mayores de 60 años y los jóvenes menores de 19 años (121).

Dosis infectiva: La enfermedad diarreica ocasionada por $B$. cereus se caracteriza por requerir un número de células viables o esporas entre $10^{5}$ y $10^{7} \mathrm{UFC} / \mathrm{g}(121)$.

\section{Bacillus cereus (Toxina Emética)}

Nombre de la enfermedad: Síndrome emético causado por B. cereus $(121,151)$.

Período de incubación: el período de incubación identificado se estima entre 1 a 6 horas (121, 153).

Síntomas: Dentro de los síntomas de esta enfermedad se encuentran naúseas, vómito y malestar; la diarrea no es común en este tipo de enfermedad $(121,156)$.

Factores de Virulencia: La toxina emética de $B$. cereus es un péptido cíclico termoestable de 1,2 $\mathrm{KDa}$, denominada cereulide ([D-O-Leu-D-Ala-L-O-Val-L-Val] $]_{3}$ ) (157), resistente al calor (es estable a $126^{\circ} \mathrm{C}$ por 90 minutos), $\mathrm{pH}$ (es estable entre 2 -11) y a la proteólisis, y está involucrada en las intoxicaciones eméticas (154). Es una toxina preformada en los alimentos de la cual se desconoce su vía sintética. Puede ser producida en forma simultanea con la toxina diarreica (155).

Modo de acción del microorganismo: El mecanismo de acción de la toxina emética es desconocido (155).

Morbilidad: Al no ser de notificación obligatoria, existe un subregistro importante por lo que las cifras aún no están totalmente esclarecidas. 
Mortalidad: Existen muy pocos casos fatales causados por B. cereus, con un caso reportado atribuido a la toxina emética (155).

Grupos de riesgo: Todos los grupos de personas son susceptibles a la intoxicación e infección, pero existe variación en la intensidad de los síntomas entre los individuos (121).

Dosis infectiva: La enfermedad diarreica ocasionada por $B$. cereus se caracteriza por requerir un número de células viables o esporas entre $10^{5}$ y $10^{8}$ células $/ g$ (121).

\subsection{Brucella spp.}

Nombre de la enfermedad: Brucelosis (158).

Período de incubación: El período de incubación de la brucelosis es variable, con un rango entre 3 y 60 días. La mayor parte de las enfermedades se presentan más o menos 1 mes después de la exposición (159).

Síntomas: En los humanos, la brucelosis tiene un amplio espectro de síntomas. Los rasgos clínicos de la brucelosis dependen del estado de la enfermedad, y del órgano y sistemas involucrados. Brucella spp. ha sido reportada por comprometer el sistema nervioso central y periférico, y los sistemas gastrointestinal, hepatobiliar, genitourinario, músculo-esquelético y cardiovascular. Así mismo, puede incluir fiebre, sudores, dolores de cabeza y de espalda y debilidad física. La principal característica de la brucelosis es la fiebre, seguida de una implicación osteoarticular, sudoración, astralgia o artritis, hepatomegalia, esplenomegalia y síntomas pasajeros (160). Cuando se presenta la brucelosis aguda, la enfermedad puede ser leve y autolimitada; cuando no existe tratamiento oportuno puede pasar a crónica donde se acentúan los síntomas. En el caso de la enfermedad de gravedad media, generalmente la recuperación se logra de 1 a 3 meses (158).

Factores de Virulencia: Los mecanismos por los que entra Brucella spp. a las células e invade las células fagociticas y no fagociticas aún son objeto de investigación y de debate. Los factores de adhesión a las células e invasión no han sido caracterizados (161). La identificación de los factores clásicos de virulencia como toxinas, cápsula o fimbrias no ha sido posible. Sin embargo, se conoce que Brucella spp. es un patógeno intracelular facultativo, condición que le permite protegerse de la acción de los antibióticos y de los mecanismos efectores dependientes de anticuerpos. De allí que la infección sea crónica, pues tienen la capacidad de adherirse, penetrar y multiplicarse en células fagocíticas como no fagocíticas (162).

Modo de acción del microorganismo: Después de atravesar la barrera protectora de la piel o de las mucosas, Brucella spp. llega a los ganglios linfáticos periféricos donde es fagocitada por los neutrófilos y macrófagos. En la fase de generalización, el microorganismo se disemina por todo 
el organismo a través de la corriente sanguínea. Aunque son capaces de colonizar prácticamente todos los órganos y tejidos, el bazo, el hígado y la médula ósea son los principales órganos diana (25).

Morbilidad: La verdadera incidencia de la brucelosis humana es desconocida. Los reportes de incidencia en áreas endémicas varían mucho, de $<0,01$ a $>200$ por 100.000 habitantes (161).

Mortalidad: La mortalidad por brucelosis es rara; sin embargo es una enfermedad altamente debilitante e incapacitante (160).

Grupos de riesgo: Todas las personas en general son susceptibles de contraer la enfermedad, pero principalmente los trabajadores en contacto con animales infectados o sus productos y personal de laboratorio. También los veterinarios y el personal de limpieza de los establos son susceptibles de adquirirla (162). Adicionalmente, durante el curso de los embarazos, las mujeres corren el riesgo de incurrir en abortos espontáneos o transmisión intrauterina a los fetos (163).

Dosis infectiva: La dosis infectiva de Brucella spp. es de 10 - 100 UFC/g o mL (164).

\subsection{Campylobacter jejuni}

Nombre de la enfermedad: Campilobacteriosis (121).

Período de incubación: El período de incubación es de 2 a 5 días $(120,165)$.

Síntomas: Los síntomas más frecuentes de la infección intestinal por $C$. jejuni son dolor abdominal, fiebre y diarrea, algunas veces acompañadas de vómito. El dolor abdominal y la fiebre pueden preceder a la diarrea. La diarrea puede ser profusa, acuosa y alternativamente sanguinolenta. Aunque la diarrea es intensa, sólo se presenta deshidratación en personas jóvenes o de edad avanzada $(124,165)$. Dentro de las secuelas y como una de las complicaciones importantes, se encuentra el Síndrome de Guillain-Barré cuyos síntomas son hormigueo, debilidad muscular y parálisis debido al daño causado en la cubierta de los nervios por desmielinización. Así mismo, en el caso de la artritis reactiva, los síntomas urinarios aparecen en los primeros días de la infección, seguidos por fiebre baja, inflamación de la conjuntiva del ojo (conjuntivitis) y artritis en el transcurso de las semanas siguientes. La artritis puede ser leve o severa y puede afectar sólo a un lado del cuerpo o a más de una articulación $(166,167)$. La enfermedad es usualmente limitada en un período de 5 a 8 días, pero puede prolongarse y la eliminación del microorganismo persiste a menudo después de que los síntomas clínicos han finalizado (165). 
Factores de Virulencia: Los mecanismos de patogenicidad de $C$. jejuni no están completamente dilucidados, pero se reconoce como un microorganismo invasivo y productor de una toxina termolábil. La enfermedad es causada por la infección del tracto intestinal. Se reconocen en $C$. jejuni, cuatro factores principales de virulencia: la motilidad, la adherencia, la invasión y la producción de toxina. La motilidad no sólo se requiere para que la bacteria alcance los sitios a los cuales se va a unir, sino que también se requiere para su penetración al interior de las células epiteliales. La adherencia a las células epiteliales es un factor importante para la colonización y puede aumentar la concentración local de productos bacterianos secretados. La invasión a través de las células refleja el mecanismo virulento mediante el cual el microorganismo causa daño, inflamación y de ese modo gastroenteritis (165, 168). Adicionalmente, se ha reportado que $\mathrm{C}$. jejuni produce al menos dos exotoxinas: una citotónica termolábil o enterotoxina (CTJ) y una citotoxina, las cuales pueden inducir a la producción de diarrea acuosa, moco sanguinolento y deposiciones con leucocitos, síntomas característicos de las enteritis causadas por este microorganismo (169).

Modo de acción del microorganismo: Al iniciar la infección, $C$. jejuni cruza la capa mucosa que cubre las células epiteliales y se adhiere a ellas. La invasión de las células epiteliales puede llevar al daño de la mucosa e inflamación la mayoría de las veces (121). En cuanto a los efectos de la enterotoxina, se sabe que ésta eleva los niveles del cAMP produciendo efectos inflamatorios (168).

Morbilidad: $C$. jejuni se ha identificado como la causa más común de diarrea infecciosa aguda en países desarrollados. Se ha estimado que en EEUU 2,5 millones de casos de campilobacteriosis se presentan anualmente. Además, Campylobacter spp. es el responsable de aproximadamente el $17 \%$ de los casos de hospitalización por infecciones transmitidas por alimentos (170).

Mortalidad: Aproximadamente 2,4 a 4 millones de casos de campilobacteriosis están asociados con 120 muertes al año (124). La proporción de casos de muerte por infección de Campylobacter spp. es de 0,1 , lo que equivale a 1 muerte por 1.000 casos (170).

Grupos de riesgo: En países industrializados los síntomas son más severos en adultos jóvenes. En países en desarrollo, hay un alto rango de portadores asintomáticos y niños de corta edad con síntomas leves donde la infección está generalmente restringida a niños, y no se conoce claramente su estacionalidad. En países industrializados, la infección es a menudo estacional y las poblaciones de riesgo son en su mayoría adultos jóvenes y niños de corta edad. Se cree que esta diferencia se debe a la temprana adquisición de inmunidad de los pacientes en países en desarrollo, seguida de una múltiple exposición a Campylobacter spp. y por la no existencia de variaciones geográficas en los tipos de cepas (165). 
Dosis infectiva: Algunos estudios sugieren que entre $4 \times 10^{2}$ a $5 \times 10^{2} \mathrm{UFC} / \mathrm{g} \circ \mathrm{mL}$ pueden causar la enfermedad. Otros estudios consideran dosis infecciosas de $5 \times 10^{2}$ a $8 \times 10^{2} \mathrm{UFC} / \mathrm{g}$ o $\mathrm{mL}(124,165)$.

\subsection{Coxiella burnetii}

Nombre de la enfermedad: Fiebre Q (171).

Período de incubación: El período de incubación corresponde de dos a tres semanas, es decir, entre 14 a 28 días (171).

Síntomas: No existe una información disponible y concluyente sobre el efecto de $C$. burnetii cuando infecta por vía oral; sin embargo, se conoce que la fiebre $Q$ es una enfermedad febril, aguda e inespecífica, en la cual la hepatitis y la neumonía atípica se presentan en los casos graves. Algunas personas pueden desarrollar una infección crónica con endocarditis valvular (171).

Factores de Virulencia: La infectividad y los factores de virulencia por vía oral se encuentran escasamente documentados; sin embargo, se han identificado genes codificadores de una proteína potencializadora de la infección de los macrófagos (Mip), cuya evidencia en otros microorganismos la señalan como una parte crucial para la infección. Así mismo, al lipopolisacarido (LPS) se le atribuyen propiedades de virulencia ya que facilita el ingreso a la célula y participa en la reorganización de los filamentos de actina para la colonización de las mismas (172).

Modo de acción del microorganismo: Los datos sugieren que $C$. burnetii, puede salir del tracto gastrointestinal y producir una infección suficiente para estimular el sistema inmune, desconociéndose el desarrollo completo de la enfermedad. Durante el proceso infeccioso, $C$. burnetii es tomada por las células huésped en los fagosomas y después de varios ciclos de replicación, es liberado en el tracto gastrointestinal donde se produce la infección (40).

Morbilidad: Este parásito intracelular no es de notificación obligatoria en todos los países; por lo tanto, existen subregistros. Sin embargo, en EEUU se ha incrementado el número de casos reportados hasta alcanzar cifras de 132 casos en el 2008 (171).

Mortalidad: Se estima que entre el $1 \%$ al $2 \%$ de personas con fiebre $Q$ aguda fallecen de esta enfermedad (173).

Grupos de riesgo: En términos generales, cualquier persona que consuma leche cruda es susceptible de infección; sin embargo, las mujeres en embarazo, pacientes con $\mathrm{VIH}$ e 
inmunocomprometidos o con tratamientos de quimioterapia, hacen parte de los grupos más susceptibles (41).

Dosis infectiva: La infectividad por via oral no ha sido totalmente esclarecida; sin embargo se ha estimado a través de modelos animales en cifras bajas de 1 microorganismo /mL (173).

\subsection{Escherichia coli enterohemorrágica 0157:H7}

Debido a su impacto en salud pública, esta evaluación de riesgo solo caracterizará la E. coli enterohemorrágica O157:H7.

Nombre de la enfermedad: Colitis hemorrágica causada por E. coli enterohemorrágico (EHEC). Considerando que las $E$. coli enterohemorragicas son las más frecuentemente involucradas en ETA, sólo se hace la caracterización de esta especie $(128,129)$.

Período de incubación: Los períodos de incubación son variables de acuerdo al tipo de cepa causante de la enfermedad. La colitis hemorrágica causada por E. coli enterohemorrágico (EHEC) usualmente tiene un período de incubación de 3 a 4 días que pueden prolongarse entre 5 y 8 días o ser más cortos entre 1 y 2 días (174).

Síntomas: La diarrea producida por E. coli enterohemorrágico (EHEC) inicialmente se presenta como no sanguinolenta, con o sin vómito, dolor abdominal y fiebre. Después de 1 o 2 días la diarrea se torna sanguinolenta y se intensifica el dolor abdominal. Tiene una duración de 4 a 10 días, con heces abundantemente sanguinolentas. Se pueden presentar complicaciones como el Síndrome Urémico Hemolítico que se caracteriza por la tríada: anemia hemolítica microangiopática, trombocitopenia e insuficiencia renal aguda, que frecuentemente sucede a un período prodrómico de diarrea con sangre en los 5 a 7 días previos, conformando el cuadro clínico clásico. Además se puede acompañar de síntomas neurológicos o respiratorios, prolapso rectal, o anuria severa (128). Se ha estimado que la recuperación de la enfermedad producida por E. coli enterohemorrágico (EHEC) es de 4 a 10 días (128).

Factores de virulencia: Aunque no se ha esclarecido totalmente el mecanismo de patogenicidad de EHEC, se han identificado varios factores de virulencia, principalmente la producción de una citotoxina con actividad en las células Vero llamada Verocitotoxina (VT) y una citotoxina semejante a la toxina de Shigella dysenteriae también llamada Shiga toxina (STX). Además de las Shiga toxinas (STX), otros factores de virulencia incluyen un plásmido que codifica para una enterohemolisina y un factor de adherencia intestinal que juega un papel importante en la adherencia del microorganismo a las células epiteliales (175). La intimina (proteína) juega un papel importante en la adherencia del microorganismo, al igual que otros factores aún en estudio (128). 
Modo de acción del microorganismo: En términos generales, las cepas de E. coli productoras de enfermedad diarreica siguen el mismo esquema de infección: colonización de un sitio de la mucosa, evasión de los mecanismos de defensa del huésped, multiplicación y daño en el huésped. La presencia de fimbrias que le ayudan a adherirse a las superficie de las células, es una propiedad que tienen casi todas las cepas de E. coli, incluyendo las no patógenas. Sin embargo, las cepas diarreicas de E. coli poseen fimbrias antigénicas específicas que aumentan su capacidad para colonizar el intestino y permiten su adherencia a la mucosa del intestino delgado que, normalmente, no es colonizado (128).

Morbilidad: EL CDC ha estimado que E. coli enterohemorrágico (EHEC) produce unas 20.000 infecciones o más en EEUU anualmente (128).

Mortalidad: El índice de mortalidad de la infección causada por E. coli enterohemorrágico (EHEC) en ancianos es del 50\% (129).

Grupos de riesgo: Todos los grupos de personas pueden presentar enfermedad diarreica por $E$. coli EHEC, pero especialmente los bebés, niños de hasta 5 años y ancianos son las poblaciones más susceptible (174).

Dosis infectiva: Se han reportado dosis infectivas de menos de $10 \mathrm{UFC} / \mathrm{mL}$ de $E$. coli enterohemorrágico (129).

\subsection{Listeria monocytogenes}

Nombre de la enfermedad: Listeriosis humana. L. monocytogenes causa dos formas de listeriosis: listeriosis gastrointestinal no invasiva y listeriosis invasiva $(121,176)$.

Período de incubación: El período de incubación del síndrome gastrointestinal se desconoce pero suele ser mayor de 12 horas (176). En los casos severos de listeriosis, este es desconocido pero puede estar entre varios días y 3 semanas. En mujeres embarazadas y personas inmuno comprometidas que adquieren la infección por el consumo de alimentos contaminados, varía de 1 día a varios meses (132). En los casos de listeriosis invasiva, se estima entre 2 y 3 semanas (176).

Síntomas: La forma invasiva de listeriosis se caracteriza por la aparición de cuadros severos como meningitis, septicemia, bacteremia primaria, endocarditis, y un síndrome parecido a la influenza con síntomas como fiebre, dolor de cabeza, fatiga, malestar y dolor abdominal. En mujeres embarazadas, la listeriosis se puede transmitir al feto a través de la placenta, incluso si la madre no presenta signos de enfermedad. Esto puede llevar al nacimiento prematuro del bebé, aborto espontáneo, nacimiento del bebé muerto o serios problemas de salud en el recién nacido. La listeriosis neonatal se presenta en los primeros 5 a 7 días después del nacimiento 
con síntomas como neumonía, bacteremia, meningitis, dificultad respiratoria, fiebre, letargia, ictericia y salpullido. La listeriosis perinatal por L. monocytogenes se presenta típicamente como una bacteremia con o sin un sitio aparente de infección, o con una infección del Sistema Nervioso Central (SNC) que incluye meningitis y meningoencefalitis. La mayoría de los casos de meningitis o meningoencefalitis causada por $L$. monocytogenes se observan en pacientes mayores de 50 años y los síntomas predominantes son fiebre, cambios en la sensibilidad y dolor de cabeza (176).

La forma no invasiva de listeriosis se presenta como una gastroenteritis febril (177) la cual, en la mayoría de los casos, presenta síntomas como diarrea, fiebre, cefalea y mialgia (176). La listeriosis no invasiva es una enfermedad autolimitante cuya fiebre y diarrea tienen una duración de 27 y 42 horas, respectivamente, y la mayoría de los pacientes se recuperan con tratamiento antimicrobiano (178).

Factores de Virulencia: La listeriosis invasiva se refiere a los casos en que una infección inicial del tejido intestinal por L. monocytogenes deriva en la invasión de partes del organismo que habitualmente son estériles, como el útero grávido, el SNC o la sangre, o la combinación de estos (179). La patogenicidad de L. monocytogenes está dada por su capacidad para adherirse, invadir y multiplicarse en diferentes clases de células, especialmente macrófagos, enterocitos, hepatocitos y células endoteliales (180). La entrada del microorganismo al hospedero se lleva a cabo en 4 etapas:

a. Supervivencia bacteriana a través de la barrera intestinal,

b. Supervivencia y multiplicación en el tracto intestinal con posibles síntomas (p. ej. diarrea),

c. Invasión de las células M y/o células epiteliales del intestino,

d. Infección de los macrófagos seguida de diseminación sistémica, septicemia, invasión cerebral e infección fetal en el caso de mujeres embarazadas (181).

El principal factor de virulencia que posee L. monocytogenes es una hemolisina llamada Listeriolisina O (LLO), que tiene la habilidad de lisar los eritrocitos y otras células favoreciendo así la multiplicación del microorganismo (182).

Modo de acción del microorganismo: Después de la ingestión del alimento contaminado con $L$. monocytogenes, la bacteria pasa directamente al estómago y cruza la barrera intestinal, presumiblemente a través de las células $\mathrm{M}$ que cubren las placas de Peyer, donde penetra y se multiplica. Luego son transportadas por la sangre a los ganglios linfáticos mesentéricos, el bazo y el hígado. Después de que entra en la célula, la bacteria se desplaza tempranamente desde el fagosoma, se multiplica en el citosol de la célula huésped, y luego se mueve a través de ella $(132,182)$. 
Morbilidad: Los casos de listeriosis invasiva no perinatal a nivel mundial tienen una incidencia de 0,1 a 1,1 casos por 100.000 habitantes y el $47 \%$ de los pacientes contagiados presentan infecciones del SNC. L. monocytogenes es ,generalmente, la tercera o cuarta causa de meningitis en Norte América y Europa Occidental $(183,184)$. En el año 2005, el CDC reportó 896 casos de listeriosis no invasiva, con una incidencia anual de 0,28 casos por 100.000 habitantes (12). En poblaciones consideradas de alto riesgo, los índices de infección son más altos; por ejemplo, en mujeres en estado de gestación, se han estimado 12 casos por 100.000 habitantes y en pacientes con VIH se han calculado 115 casos por 100.000 habitantes (184).

Mortalidad: En los últimos años, la listeriosis se ha convertido en una de las mayores preocupaciones de salud pública debido a su severidad, su prolongado tiempo de incubación y su alta tasa de mortalidad que oscila entre un 20 y $30 \%(170,185,186)$ en los grupos de riesgo. En personas mayores o inmunocomprometidas alcanza valores de $38-40 \%$ (121).

Grupos de riesgo: $L$. monocytogenes causa enfermedad invasiva principalmente en grupos de riesgo bien definidos, incluyendo personas inmunocomprometidas, mujeres embarazadas, niños recién nacidos y ancianos $(187,188)$.

Dosis infectiva: La dosis infectiva de L. monocytogenes puede variar de acuerdo con la virulencia e infectividad del patógeno, al tipo y cantidad del alimento consumido, a la concentración del microorganismo en el alimento y a la susceptibilidad del huésped. En términos generales la dosis infectiva puede alcanzar cifras hasta de $10^{9} \mathrm{UFC} / \mathrm{g}$; y en grupos de riesgo, se ha indicado que la dosis infectiva es baja, alrededor de $10^{3} \mathrm{UFC} / \mathrm{g}$ de alimento (188, 189).

\subsection{Mycobacterium bovis}

Nombre de la enfermedad: Tuberculosis $(190,191)$

Período de incubación: Se ha establecido el periodo de incubación entre 2 a 10 semanas (192).

Síntomas: Los síntomas suelen aparecer meses o años después de la infección y clínicamente son indistinguibles de la forma clásica de tuberculosis, sin embargo, la infección oral puede afectar al SNC, al sistema óseo y algunos órganos como los riñones. En mujeres, puede presentar síntomas al establecerse el microorganismo en los ganglios linfáticos y el cuello del útero. También se pueden presentar tos productiva, fiebre, dolores en el pecho, pérdida de peso o dolor de estómago (191).

Factores de virulencia: Los factores de virulencia de $M$. bovis son los mismos atribuidos a $M$. tuberculosis, los cuales le permiten infectar, sobrevivir, multiplicarse y causar enfermedad. Aún no se conoce con claridad cuáles son estos factores de virulencia; sin embargo, los lípidos de la 
pared celular son considerados atributos patogénicos importantes. La patogenicidad de este tipo de bacilos parece ser multifactorial y aún poco dilucidada. Al igual que en otras micobacterias, en $M$. bovis es conocido el "factor de cordón" como uno de los factores asociados a su virulencia y relacionado con el alineamiento en paralelo de las filas de los bacilos observadas al microscopio (193).

Modo de acción del microorganismo: La ingestión por vía oral del microorganismo conlleva a manifestaciones extrapulmonares de la tuberculosis, por lo que se requiere mayor investigación desde la vía de entrada (194).

Morbilidad: La información sobre la morbilidad causada por $M$. bovis es limitada, en parte debido a la dificultad de diferenciarlo de la forma clásica de enfermedad trasmitida por $M$. tuberculosis. Sin embargo, en algunos países se estima superior al 35\%

Mortalidad: Estudios reportan que la mortalidad causada por $M$. bovis puede llegar a ser superior a la causada por $M$. tuberculosis sin discriminar la enfermedad extrapulmonar de la forma clásica de tuberculosis, estimándose entre 5.2\% a 19.9\% (190).

Grupos de riesgo: Aunque todas las personas son susceptibles de infección, los niños y jóvenes y pacientes con $\mathrm{VIH}$, son los principales grupos de riesgo (192).

Dosis infectiva: Se presume que la dosis infectiva corresponde a cifras altas, pero aún se encuentra en estudio (191).

\subsection{Salmonella spp.}

Nombre de la enfermedad: Salmonelosis (121).

Período de incubación: Las infecciones humanas por Salmonella no tifoidea acaban en una enterocolitis cuyo período de incubación varía desde las 5 horas hasta los 5 días (164).

Síntomas: Los síntomas incluyen diarrea, nauseas, dolor abdominal, fiebre ligera y escalofríos. La diarrea varía desde muy pocas heces claras hasta evacuaciones sólidas con la deshidratación correspondiente y algunas veces con sangre $(121,145)$. La aparición de los signos y síntomas empiezan 12 a 36 horas después de la ingestión de un alimento contaminado (164). La gastroenteritis suele durar de 2 a 5 días (145).

Factores de Virulencia: La infección humana por Salmonella spp. depende de la capacidad del microorganismo para fijarse y penetrar en las células del epitelio intestinal y en las células $M$ que cubren las placas de Peyer. Los plásmidos de virulencia le permiten multiplicarse rápidamente en las células huésped y vencer los mecanismos de defensa del hospedador. La 
enterotoxina diarreica es uno de los factores de virulencia más importante de Salmonella spp. debido a su capacidad para inducir síntomas clínicos como la diarrea en los casos de salmonelosis humana (121).

Modo de acción del microorganismo: Salmonella spp. invade la luz del intestino delgado, donde se multiplica. Después atraviesa el íleon, y en menor grado el colon, donde se produce una reacción inflamatoria. Los folículos linfáticos pueden aumentar de tamaño y se pueden ulcerar. Los ganglios mesentéricos con frecuencia se inflaman. A veces, atraviesan las barreras mucosa y linfática, llegan a la corriente sanguínea y originan abscesos en varios tejidos. Las cepas invasoras atraviesan la mucosa intestinal, pasan al sistema linfático y son englobadas por los fagocitos en cuyo interior se multiplican. Después, estas bacterias vuelven a entrar en la corriente sanguínea, causando septicemia (121).

Morbilidad: Se ha estimado que de 2 a 4 millones de casos de salmonelosis ocurren anualmente en EEUU. El 20\% de los pacientes requieren de hospitalización. La infección por Salmonella no tifoidea resistente a antibióticos y por Salmonella Typhi aumentan la posibilidad de hospitalización y muerte (145). Adicionalmente, la salmonelosis causada por cepas no tifoideas pueden evolucionar en infecciones sistémicas y enfermedades crónicas tales como artritis reactiva antiséptica, el síndrome de Reiter y espondilitis anquilosante (121).

Mortalidad: El índice de mortalidad es de aproximadamente el 0,6\%. Salmonella dublin tiene un $15 \%$ de mortalidad y Salmonella enteritidis ha demostrado aproximadamente un 3,6\% de mortalidad (145).

Grupos de riesgo: Todos los grupos de personas son susceptibles, aunque los síntomas más graves se observan en ancianos, niños, recién nacidos y personas inmunocomprometidas. Los pacientes con VIH sufren frecuentemente de salmonelosis y de episodios recurrentes (145).

Dosis infectiva: Algunos estudios han indicado que la dosis infectiva es baja, de 15 a 20 UFC/mL y depende en gran parte de la edad y estado de salud del huésped así como de la cepa y de las diferencias entre las especies del género (121).

\subsection{Staphylococcus aureus enterotoxigénico}

Nombre de la enfermedad: Intoxicación alimentaria estafilocócica (SPF) (151).

Periodo de incubación: El período de incubación es corto, entre 1 a 4 horas $(107,147)$.

Síntomas: Los síntomas gastrointestinales aparecen poco tiempo después de ingerir el alimento contaminado, estimándose su aparición entre 1 y 6 horas, mientras que otros efectos neurológicos y hematológicos pueden aparecer después de un tiempo prolongado. Los 
síntomas pueden ir desde leves a moderados y severos e incluyen espasmos abdominales, nauseas, vómitos, diarrea, fiebre y deshidratación en casos severos. En los casos graves se pueden presentar cefalea y colapso (195). La curación es rápida y espontanea, generalmente en un plazo de 1 a 2 días (147).

Factores de Virulencia: S. aureus cuenta con diversos factores de virulencia, dentro de los cuales, las toxinas estafilocócicas (ST), causantes de la SPF contribuyen a la patogenicidad del microorganismo $(196,197)$. Así mismo, S. aureus produce una amplia variedad de proteínas tóxicas como la toxina 1 del síndrome de shock tóxico (TSST1), toxinas exfoliativas y enterotoxinas (SEs), de las cuales solo las SEs han sido reportadas como productoras de intoxicación estafilocócica alimentaria (198). De los cinco tipos antigénicos de enterotoxinas estafilocócicas (SE) que tradicionalmente se conocen (SEA, SEB, SEC, SED y SEE), la SEA es la más comúnmente asociada con brotes de intoxicación alimentaria seguida de la SED, SEB y SEC (197, 198). En los últimos años se ha reportado la existencia de nuevos tipos de SEs, incluyendo la pseudoenterotoxina (SEI) y las toxinas SEG, SEH, SEI, SEJ (199-201); de estas, las SEG, SEH y SEI, también han sido asociadas con casos de intoxicación alimentaria (202). Recientemente, se han descrito nuevos tipos de enterotoxinas estafilocócicas (SEK, SEL, SEM, SEN, SEO, SEQ, SER, SET, SEU y SEV) (203).

Las SEs son reconocidas por su resistencia al calor la cual es diferente en cada toxina, y por lo tanto resistirán el proceso de pasteurización de la leche; por ejemplo, la SEC es más resistente que la SEB, que a su vez es más resistente que la SEA. Igualmente, la SEE tiene una estructura más estable que la SEA, mientras que la SEI es menos estable que la SEA (204). Los tipos SEB y SEC son producidas principalmente al final de la fase estacionaria del crecimiento como metabolitos secundarios; los tipos SEA y SEE son producidas durante toda la fase logarítmica del crecimiento (121).

Además de $S$. aureus, varias especies coagulasa negativa como S. cohnii, $S$. epidermis, $S$. xylosus y $S$. haemolyticus, pueden producir una o varias SEs (205). Especies de estafilococos coagulasa positiva como $S$. intermedius y $S$. hyicus también pueden producir SEs y han sido claramente implicadas en brotes de intoxicación alimentaria estafilocócica $(206,207)$.

Modo de acción de la toxina: El modo de acción de las SEs no ha sido esclarecido, pero se cree que tanto el vómito como la diarrea resultan por la estimulación de neuro-receptores locales, existentes en el tracto gastrointestinal y por la transmisión de estímulos al centro del vómito del cerebro a través del nervio vago y otras partes del sistema nervioso simpático. Estudios han demostrado que muchos de los efectos de la SEB son mediados por la estimulación de los linfocitos $T$ del sistema inmunológico del huésped. La toxina se une directamente a las proteínas clase II del complejo mayor de histocompatibilidad (MHC) estimulando la proliferación de linfocitos T (146). 
Morbilidad: $S$. aureus es considerado como la tercera causa en el mundo de enfermedades transmitidas por alimentos (208). A excepción de Francia y EEUU no hay datos disponibles de índices de hospitalización por SPF. Estos índices son del 15 y 18\% de casos reportados de $S$. aureus en Francia y EEUU, respectivamente $(170,209)$.

Mortalidad: La mortalidad asociada a este microorganismo es baja, ya que los datos existentes en EEUU revelan solo un $0,1 \%$ de muertes causadas por la SPF (170).

Grupos de riesgo: Todas las personas pueden presentar esta intoxicación; sin embargo, la sintomatología puede ser variable dependiendo de la susceptibilidad del individuo y de la cantidad y tipo de toxina ingerida (210), siendo más vulnerables los niños.

Dosis infectiva: Considerando el número de microorganismos presentes en el alimento, algunas investigaciones reportan que se requieren conteos bacterianos entre $10^{5}$ y $10^{6} \mathrm{UFC} / \mathrm{g}$ para que las toxinas de $S$. aureus puedan causar una intoxicación alimentaria $(201,211)$. De otra parte, la dosis de toxina requerida para inducir los síntomas de la SPF en humanos está estimada en alrededor de $0,1 \mu \mathrm{g}$, aunque se han reportado estudios que indican que la dosis para un adulto puede estar entre 10 y $20 \mu \mathrm{g}$, y otros sugieren que la intoxicación estafilocócica puede presentarse después de la ingestión de menos de 1 ng de toxina estafilocócica $(146,207,212)$.

\subsection{Yersinia enterocolitica}

Nombre de la enfermedad: Yersiniosis (152).

Período de incubación: El período de incubación de la yersiniosis se estima entre 3 y 7 días, siendo generalmente inferior a 10 días, aunque algunos reportes lo mencionan entre 1 y 14 días (121).

Síntomas: Los síntomas como gastroenteritis, con diarrea y/o vómito; adicionalmente, fiebre y dolor abdominal son también característicos y pueden enmascararse como una apendicitis; la yersiniosis aguda con frecuencia se presenta en forma de síndrome pseudoapendicular (121).

Factores de Virulencia: Aunque no es totalmente conocido el mecanismo de patogenicidad de $Y$. enterocolitica se conoce que es de tipo invasivo e induce la respuesta inflamatoria de los tejidos infectados. Algunas evidencias sugieren que la invasión tiene lugar a través de las células $\mathrm{M}$ de las placas de Peyer del intestino, multiplicándose en el tejido linfoide, desde donde puede propagarse a otros sitios (121). Existen también otros factores de virulencia tales como un plásmido de virulencia o una enterotoxina termoestable, cuyo papel no está completamente esclarecido (213-215). 
Modo de acción del microorganismo: La determinación de la patogenicidad es muy compleja y se conoce que $Y$. enterocolitica penetra en el tracto gastrointestinal (121), desde donde puede invadir otros tejidos. Además, las cepas altamente invasivas son productoras de enterotoxina. Los mecanismos de virulencia aún no han sido completamente esclarecidos.

Morbilidad: La yersiniosis no es frecuente; sin embargo, se estima que ocurren alrededor de 17.000 casos por año en EEUU reportados por el CDC. Esta enfermedad está asociada a artritis reactiva (216).

Mortalidad: La mortalidad asociada a este microorganismo es baja, cercana al 0,5\% (170).

Grupos de riesgo: El grupo de riesgo está compuesto por los niños, jóvenes, ancianos y personas inmunocomprometidas. Casi todas las infecciones sintomáticas con $Y$. enterocolitica se presentan en niños, especialmente menores de 5 años de edad (121).

Dosis infectiva: La dosis infectiva es desconocida, pero es probable que exceda las $10^{4} \mathrm{UFC} / \mathrm{g}$ (121). 


\section{EVALUACIÓN DE LA EXPOSICIÓN}

\subsection{ECOLOGÍA DE LOS MICROORGANISMOS PATÓGENOS ENCONTRADOS EN LECHE CRUDA}

La leche obtenida de la secreción mamaria de bovinos sanos, usualmente estéril, posee propiedades físico-químicas que brindan un medio ideal para el desarrollo de microorganismos patógenos, lo cual, asociado con prácticas inadecuadas de producción y manufactura, la convierten en un alimento susceptible de contaminarse (9-11). Según Millogo et al. (2010) (217) la leche cruda es extraída de la ubre de la vaca a una temperatura promedio de $30,2 \pm 0,6^{\circ} \mathrm{C}$ y a

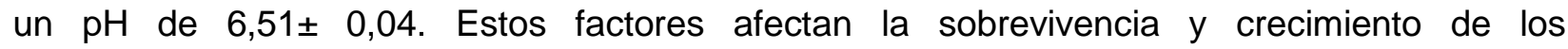
microorganismos patógenos más ampliamente asociados a brotes por consumo de leche cruda (ver Tabla 6).

Tabla 6. Resumen de los límites de crecimiento y sobrevivencia de los microorganismos patógenos asociados a brotes por consumo de leche cruda

\begin{tabular}{|c|c|c|c|c|c|c|c|c|}
\hline \multirow{2}{*}{\multicolumn{2}{|c|}{ Microorganismo }} & \multicolumn{3}{|c|}{ Temperatura $\left({ }^{\circ} \mathrm{C}\right)$} & \multicolumn{3}{|c|}{$\mathrm{pH}$} & \multirow{3}{*}{$\begin{array}{c}\text { Referencia } \\
(218)\end{array}$} \\
\hline & & \multirow{2}{*}{$\begin{array}{c}\text { Min } \\
4\end{array}$} & \multirow{2}{*}{\begin{tabular}{|c|} 
Max \\
55
\end{tabular}} & \multirow{2}{*}{$\frac{\text { Opt }}{30-40}$} & \multirow{2}{*}{$\begin{array}{c}\text { Min } \\
4,5\end{array}$} & \multirow{2}{*}{$\begin{array}{c}\text { Max } \\
9,5\end{array}$} & \multirow{2}{*}{$\begin{array}{l}\text { Opt } \\
6-7\end{array}$} & \\
\hline & Crecimiento & & & & & & & \\
\hline B. cereus & Supervivencia $^{*}$ & - & $100^{*}$ & - & $1,0^{*}$ & - & - & (218) \\
\hline Brucella spp. & Crecimiento & 20 & 42 & 37 & $4,1-4,5$ & $8,4-8,7$ & $6,6-7,4$ & (10) \\
\hline \multirow{2}{*}{ Campylobacter spp. } & Crecimiento & 30,5 & 45 & 42 & 4,9 & 9,0 & $6,5-7,5$ & (219) \\
\hline & Supervivencia & 2 & 60 & - & 4,0 & - & - & (219) \\
\hline \multirow{2}{*}{ E. coli patógenos } & Crecimiento & $7-8$ & 46 & 37 & 4,4 & 9,0 & $6-7$ & (220) \\
\hline & Supervivencia & -20 & 71 & - & 1,5 & - & - & (220) \\
\hline \multirow{2}{*}{ L. monocytogenes } & Crecimiento & $-1,5$ & 45 & 37 & 4,4 & 9,4 & 7,0 & (221) \\
\hline & Supervivencia & -18 & 70 & - & 3,6 & - & - & (222) \\
\hline \multirow{2}{*}{ M. bovis } & Crecimiento & 30 & 45 & 37 & - & - & - & (223) \\
\hline & Supervivencia & - & 63.5 & - & - & - & - & (224) \\
\hline \multirow{2}{*}{ Salmonella spp. } & Crecimiento & 7 & 49,5 & $35-37$ & 3,8 & 9,5 & $7,0-7,5$ & $(225)$ \\
\hline & Supervivencia & -23 & 90 & - & - & - & - & $(225,226)$ \\
\hline \multirow{2}{*}{ S. aureus Enterotoxigénico } & \begin{tabular}{|c|} 
Crecimiento \\
\end{tabular} & 6 & 48 & 37 & 4,2 & 9,3 & $7,0-7,5$ & (227) \\
\hline & \begin{tabular}{|l|} 
Supervivencia \\
\end{tabular} & - & - & - & 2,3 & - & - & (227) \\
\hline \multirow{2}{*}{ Y. enterocolitica } & Crecimiento & $-1,3$ & 42 & $25-37$ & $4,2-4,8$ & $9,6-10,0$ & 7,2 & (228) \\
\hline & \begin{tabular}{|l|} 
Supervivencia \\
\end{tabular} & - & 65 & - & - & - & - & (228) \\
\hline
\end{tabular}

${ }^{*}$ Esporas 


\subsubsection{Bacillus cereus}

B. cereus es anaerobio facultativo y requiere la presencia de oxígeno para la producción de la toxina emética (155). Sus esporas pueden resistir largos periodos en el suelo (154) y por la naturaleza de la leche éstas pueden germinar y multiplicarse en ella. La resistencia al calor de sus esporas se ha reportado como $\mathrm{D}$ a $85^{\circ} \mathrm{C}$ de 1,8 a 19,1 minutos en leche (10).

\subsubsection{Brucella spp.}

Brucella spp. es excretada en la leche de bovinos y puede permanecer viable en la leche por más de 4 meses (229). Puede sobrevivir en diversos ambientes como: suelo y estiércol durante 80 días; polvo de 15 a 40 días; fluidos y secreciones en verano de 10 a 30 minutos; agua a $37^{\circ} \mathrm{C}$ y pH 7,5 menos de 1 día; agua a $8^{\circ} \mathrm{C}$ y pH 6,5; paja durante 29 días; grasa de ordeño 9 días; heces bovinas de 1 a 100 días y tierra húmeda a temperatura ambiente 66 días (162). Es importante señalar que el microorganismo no se multiplica en estos ambientes.

Stumbo (1973), reportó que el valor D estimado para Brucella spp en leche se encuentra a $65,5^{\circ} \mathrm{C}$ de 0,10 a 0,20 minutos (10).

\subsubsection{Campylobacter spp.}

Campylobacter spp. es uno de los microorganismos patógenos que puede estar presente directamente en la leche, pese a que es un microorganismo difícil de cultivar debido a sus requerimientos de condiciones estrictas de microaerofilia, puede adaptarse a condiciones de aeorobiosis (230).

Este microorganismo generalmente requiere niveles reducidos de oxígeno para su óptimo crecimiento, con presencia de 3 a $5 \%$ de oxígeno y 2 a $10 \%$ de dióxido de carbono. Sobrevive mejor a temperaturas entre $2^{\circ} \mathrm{C}$ y $20^{\circ} \mathrm{C}$ que a temperatura ambiente y máximo hasta 15 días (219). Según la Agencia de Seguridad Alimentaria de Nueva Zelanda (NZFSA) "la sobrevivencia en los alimentos es mejor a temperatura de refrigeración que a temperatura ambiente, puede llegar a ser 15 veces más resistente a $2^{\circ} \mathrm{C}$ que a $20^{\circ} \mathrm{C}$ " (219).

Se inactiva rápidamente por calentamiento a temperaturas iguales o superiores a $55^{\circ} \mathrm{C}$. El valor $\mathrm{D}$ a $50^{\circ} \mathrm{C}$ es de 1 a 6,3 minutos, el valor $\mathrm{D}$ a $55^{\circ} \mathrm{C}$ es de 0,6 a 2,3 minutos y el valor $\mathrm{D}$ a $60^{\circ} \mathrm{C}$ es de 0,2 a 0,3 minutos. Puede ser sensible a la desecación pero bajo ciertas condiciones de refrigeración puede permanecer viable por varias semanas. Es sensible a concentraciones por encima de $1 \%$ de $\mathrm{NaCl}$ y su muerte ocurre lentamente a $2 \%$. También es sensible a desinfectantes y sanitizantes como el cloro, a los rayos gamma y ultravioleta (219). 


\subsubsection{Coxiella burnetii}

Por la naturaleza intracelular de este microorganismo, la información disponible es limitada (127), sin embargo se ha demostrado su naturaleza acidofílica $(4,5-5,0)$.

Tiene la habilidad de sobrevivir periodos prolongados en el medio ambiente, siendo altamente resistente a la presión osmótica, desecación y luz UV (231). Vanderlinde (2004) y Weiss y Moulder (1984) establecieron que $C$. burnetii resiste temperaturas elevadas y que su inactivación quizá no sea alcanzada a $63^{\circ} \mathrm{C}$ por 30 minutos o de 85 a $90^{\circ} \mathrm{C}$ por pocos segundos. Se recomienda la pasteurización a $72^{\circ} \mathrm{C}$ por 15 segundos para lograr la completa eliminación de células viables de $C$. burnetii (10).

\subsubsection{Escherichia coli patógenas}

E. coli sobrevive bien en alimentos refrigerados y congelados, así como en ambientes con bajo $\mathrm{pH}(<3,6)$. En estas condiciones, el microorganismo muere lentamente y su resistencia depende del grado de contaminación. En atmósferas con $100 \%$ de $\mathrm{CO}_{2}$ se aumenta la supervivencia de células no estresadas tanto a $4^{\circ} \mathrm{C}$ como a $10^{\circ} \mathrm{C}(220)$.

Se destruye a temperaturas de calentamiento de $71^{\circ} \mathrm{C}$. Tiene valores $D_{54.4}$ de 40 minutos, $D_{60}$ de 0,5 a 0,75 minutos y $\mathrm{D}_{64.3}$ de 0,16 minutos. Su inactivación frente a pH ácidos depende del acidulante y de la temperatura. En ausencia de materia orgánica, el cloruro de benzalconio y el etanol con agua a $70^{\circ} \mathrm{C}$ son sanitizantes efectivos frente a $E$. coli. Es sensible a la radicación UV y gamma (220). La leche constituye un excelente medio para el crecimiento de cepas de $E$. coli (232).

\subsubsection{Listeria monocytogenes}

La temperatura óptima de crecimiento de $L$. monocytogenes está entre 30 y $37^{\circ} \mathrm{C}$. Dado que la temperatura de la leche al salir de la ubre es de aproximadamente $37^{\circ} \mathrm{C}$, si $L$. monocytogenes está presente en ella a causa de alguna infección intramamaria o por contaminación de la ubre o contacto con el suelo o con materia fecal, puede multiplicarse rápidamente (233). Aunque el $\mathrm{pH}$ de la leche puede bajar desde su recolección hasta su consumo, este sigue siendo un medio propicio para el crecimiento de $L$. monocytogenes. $L a a_{w}$ de la leche cruda de 0,98 también favorece su multiplicación dado que este microorganismo crece a una $a_{w}$ superior de 0,92 (221, 234).

Por ser un microorganismo psicrotrófo crece fácilmente en temperaturas de refrigeración (235); así mismo puede sobrevivir por largos períodos de tiempo en el suelo, dependiendo de las condiciones medioambientales (221), ya que es un microorganismo ubicuo que está presente naturalmente en él (10). 
L. monocytogenes se inactiva a temperaturas superiores a los $70^{\circ} \mathrm{C}$. El valor $\mathrm{D}$ a $60^{\circ} \mathrm{C}$ es de 5 a 10 minutos y a $70^{\circ} \mathrm{C}$ es de aproximadamente 10 segundos. Es inactivada a valores de $\mathrm{pH}$ menores de 4,4, dependiendo de la temperatura. Estudios han reportado que células de $L$. monocytogenes suspendidas en leche entera han sido destruidas a $71,7^{\circ} \mathrm{C}$ por 15 segundos (236). Sanitizantes y desinfectantes como aldehídos, alcoholes, fenoles y compuestos de amonio cuaternario son efectivos en ausencia de materia orgánica. El hipoclorito de sodio no es efectivo frente a $L$. monocytogenes. Para remover las biopelículas que forma el microorganismo en las superficies, se pueden utilizar amonios cuaternarios alcalinos, los cuales han sido reportados como buenos limpiadores químicos (132).

\subsubsection{Mycobacterium bovis.}

M. bovis es un microorganismo de crecimiento muy lento, microaerofílico y que sobrevive mejor en épocas de frio. Se ha demostrado, por ejemplo, que sobrevive 5 meses en bovinaza en época de invierno y 2 meses en verano. La pasteurización es un método eficaz para su inactivación, se ha demostrado que inóculos de $10^{5}$ células $/ \mathrm{mL}$ son indetectables después de un tratamiento a $63,5^{\circ} \mathrm{C}$ por 30 minutos. Es inactivado por luz solar (224).

\subsubsection{Salmonella spp.}

Salmonella spp., al igual que la mayoría de los patógenos, puede multiplicarse rápidamente en la leche cruda. La temperatura, así como el $\mathrm{pH}$ y $\mathrm{a}_{\mathrm{w}}$ de la leche durante su obtención y procesamiento, resultan favorables para que el microorganismo se desarrolle (10).

Este microorganismo puede sobrevivir largos períodos de tiempo bajo refrigeración. Su inactivación ocurre durante la congelación, pero algunas células pueden permanecer viables. Bradshaw et al. (1990) (237), calcularon el valor D para $S$. Typhimurium el cual es de $71,1^{\circ} \mathrm{C}$ de 0,22 segundos, lo cual indica que $S$. Typhimurium puede ser destruida por la pasteurización HTST (alta temperatura/corto tiempo) a $71,7{ }^{\circ} \mathrm{C}$ por 15 segundos. El tiempo $\mathrm{D}$ a $60^{\circ} \mathrm{C}$ es, usualmente, de 2 a 6 minutos y el tiempo $\mathrm{D}$ a $70^{\circ} \mathrm{C}$ es de 1 minuto o menos (225).

\subsubsection{Staphylococcus aureus enterotoxigénico}

S. aureus crece a una temperatura óptima entre 30 y $37^{\circ} \mathrm{C}$; a esta temperatura, el microorganismo puede multiplicarse fácilmente en la leche recién ordeñada en caso de estar presente en ella a causa del ordeño de animales con mastitis, o por contaminación a través de equipos, utensilios $\mathrm{u}$ operarios. El $\mathrm{pH}$ y la $\mathrm{a}_{\mathrm{w}}$ de la leche favorecen la multiplicación del microorganismo $(147,148,238)$. 
La toxina estafilocócica es producida por el microorganismo a temperaturas óptimas entre 40 y $45^{\circ} \mathrm{C}$ (Tabla 7), sin embargo, en la leche cruda se necesita un número de $10^{6} \mathrm{UFC} / \mathrm{mL}$ para que la toxina sea producida entre 6 horas a $35^{\circ} \mathrm{C}, 18$ horas a $25^{\circ} \mathrm{C}$ y 36 horas a $20^{\circ} \mathrm{C}$. Así mismo, se ha reportado que con solo $10^{4} \mathrm{UFC} / \mathrm{mL}$ se ha producido enterotoxina en 12 horas a $35^{\circ} \mathrm{C}$. Aunque el $\mathrm{pH}$ y la $\mathrm{a}_{\mathrm{w}}$ de la leche pueden favorecer la producción de la toxina, estos pueden variar de acuerdo al tipo de toxina y a la temperatura y el tiempo que el microorganismo requiere para su producción (148).

Tabla 7. Parámetros para la producción de la toxina estafilocócica

\begin{tabular}{lccc}
\hline Parámetro & Mínimo & Máximo & Óptimo \\
\hline Temperatura & $10^{\circ} \mathrm{C}$ & $48^{\circ} \mathrm{C}$ & 40 a $45^{\circ} \mathrm{C}$ \\
$\mathrm{pH}$ & 4,5 & 9,6 & $7,0 \mathrm{a} 8,0$ \\
Actividad de agua $\left(\mathrm{a}_{\mathrm{w}}\right)$ & 0,83 & $>0,99$ & 0,98 \\
\hline
\end{tabular}

Fuente: Adams,2009 (147).

S. aureus es destruido rápidamente mediante la cocción y la pasteurización y es completamente inactivado en leche después de la aplicación de las siguientes temperaturas y tiempos: $57,2^{\circ} \mathrm{C} / 80$ minutos, $60,0^{\circ} \mathrm{C} / 24$ minutos, $62,8^{\circ} \mathrm{C} / 6,8$ minutos, $65,6^{\circ} \mathrm{C} / 1,9$ minutos y $71,7^{\circ} \mathrm{C} / 0,14$ minutos (148). Algunos estudios han reportado que con un valor $z$ entre $10^{\circ} \mathrm{C}$ y $5^{\circ} \mathrm{C}$ en proceso altas temperaturas/corto tiempo (HTST) $\left(72^{\circ} \mathrm{C} / 15\right.$ segundos) aplicado a la leche, puede reducir el número de células viables de $S$. aureus de 4 a más de 6 ciclos logarítmicos (147).

En el caso de las toxinas, la SEB, por ejemplo, tiene un valor $D$ de $149^{\circ} \mathrm{C}$ por 100 minutos con un $a_{w}$ de 0,99 y 225 minutos a un $a_{w}$ de $0,90(147,227)$; esta toxina tiene una excepcional resistencia al calor con valores $D$ de segundos o pocos minutos dependiendo del medio y de la fase de crecimiento de las células. Por lo anterior, es importante evitar su producción debido a la dificultad para su inactivación. Sanitizantes y desinfectantes como el cloro, halógenos y amonios cuaternarios son efectivos para destruir a $S$. aureus en superficies (227).

\subsubsection{Yersinia enterocolitica}

Es un microorganismos facultativo anaerobio que crece hasta concentraciones de sal de $5 \%$ y se ve inhibido en concentraciones del $7 \%$. El valor $\mathrm{D}$ a $55^{\circ} \mathrm{C}$ es de $0,2 \mathrm{~min}$ y a $65^{\circ} \mathrm{C} 2 \mathrm{seg}$. La pasteurización es eficaz para la inactivación de Yersinia spp. (239). 


\subsection{CADENA DE PRODUCCIÓN DE LA LECHE CRUDA}

\subsubsection{PRODUCCIÓN LECHERA EN COLOMBIA}

En Colombia se presentan dos tipos de sistemas de producción de leche, el especializado (LE) y el doble propósito (DP), cada uno establecido en regiones diferentes del territorio nacional. La lechería especializada se localiza en las zonas del trópico alto como el altiplano cundiboyacense, altiplano nariñense, altiplano norte y nordeste de Antioquia, donde la temperatura ambiente se encuentra en promedio entre 12 y $15^{\circ} \mathrm{C}$. Este sistema se caracteriza por presentar la mayor adaptación de las razas Bos taurus (Holstein, Jersey, Normando, Pardo Suizo, Guernsey y Ayrshire), un uso intensivo de los factores de producción (tierra, capital y mano de obra), uso de fertilizantes, riego, rotación de praderas, utilización de suplementos alimenticios y dos ordeños en el día (240).

El sistema doble propósito, se localiza en las zonas del trópico bajo como la Costa Atlántica, valles de los ríos Magdalena, Cauca, Piedemonte Llanero y Caqueteño, donde las temperaturas oscilan entre 30 y $40^{\circ} \mathrm{C}$, caracterizándose por ser una ganadería de tipo extensivo debido a la alta disponibilidad de tierras en estas zonas. Su producción de leche se hace con base en las razas cebuínas (Bos indicus) o sus cruces con las razas europeas (Bos taurus) (241).

La producción lechera se concentra en 4 regiones: Atlántica, Occidental, Central y Pacífica con el predominio de importantes cuencas lecheras como en el norte de Antioquia, Cordón de Ubaté en Cundinamarca, Nariño y la Sabana de Bogotá (19). Las épocas de lluvias y sequías marcan los volúmenes de producción lechera, debido a la disponibilidad de pastos, siendo el período de mayo a agosto el de mayor producción lechera; sin embargo, se pueden presentar variaciones asociadas a las zonas geográficas (241).

En la figura 1 se representa la producción primaria de la leche y algunas de las vías de comercialización de la leche cruda que existen en Colombia. 

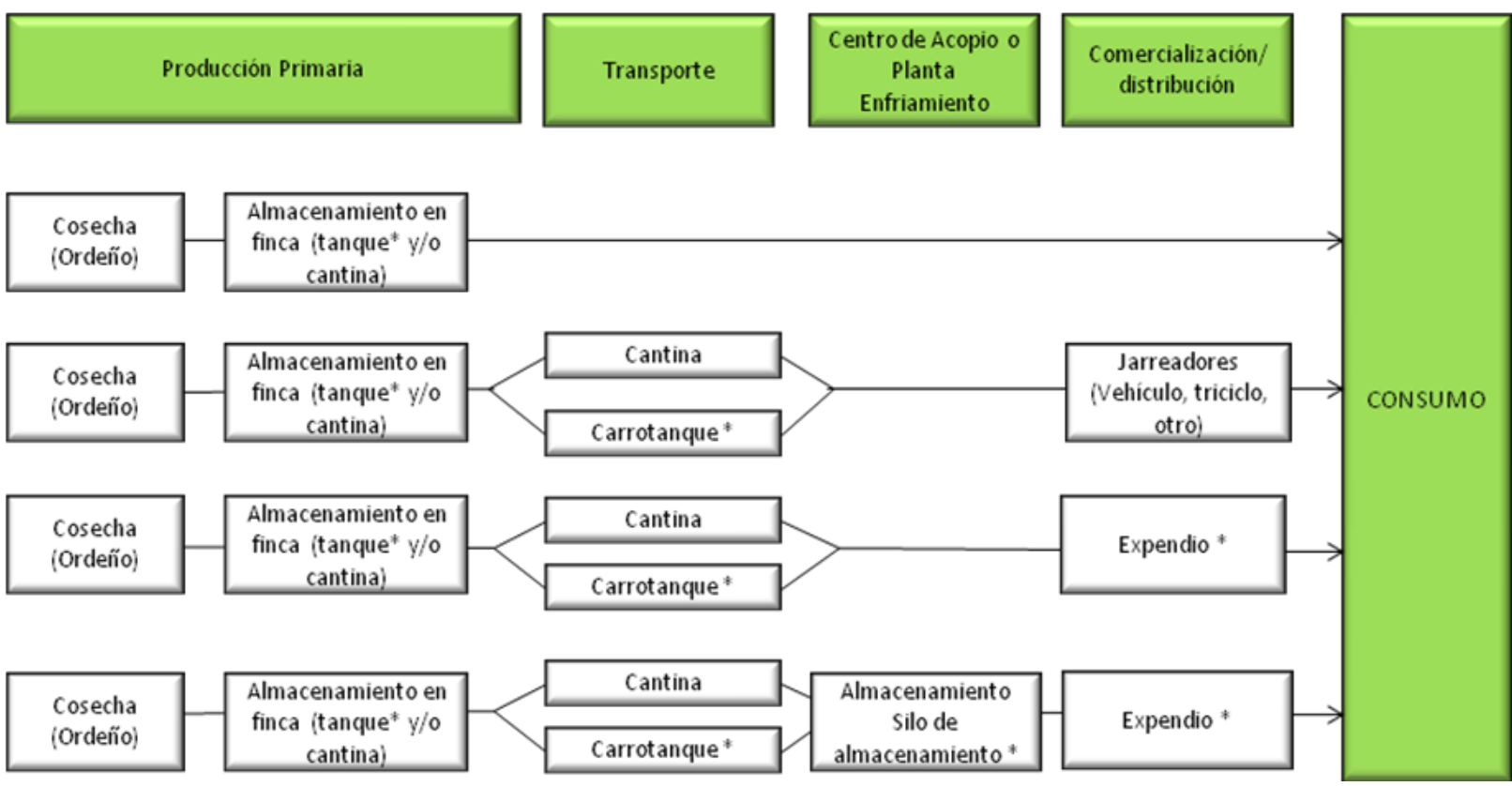

*Etapa en la cual existe la posibilidad de que el producto se almacene bajo condiciones de refrigeración

Figura 1 Producción primaria de la leche y algunas de las vías de comercialización de la leche cruda que existen en Colombia

\subsubsection{FUENTES DE CONTAMINACIÓN EN LA PRODUCCIÓN DE LECHE CRUDA PARA CONSUMO HUMANO DIRECTO}

La presencia de microorganismos patógenos en leche cruda, refleja las deficiencias sanitarias durante el proceso de producción. La calidad de la leche cruda se establece con bases en parámetros higiénicos, sanitarios y composicionales, los cuales inciden de manera representativa en la vida útil de este producto (242). Existen pocos estudios enfocados en la caracterización microbiológica de la leche cruda, los cuales se centran principalmente en identificar los microorganismos patógenos más representativos (243), entre los que se encuentran B. cereus, Brucella spp., Campylobacter spp., C. burnetii, E. coli, L. monocytogenes, Mycobacterium spp., Salmonella spp., S. aureus y $Y$. enterocolitica. Estos patógenos pueden llegar a la leche cruda provenientes de animales infectados, heces, piel de los animales, agua, suelo, polvo, manipuladores, equipos y utensilios contaminados (21).

En la tabla 8 se presentan datos de aislamientos de patógenos de muestras en Estados Unidos, donde se observa que existen muchas fuentes de contaminación con patógenos a lo largo de la cadena primaria. 
Tabla 8. Aislamiento de patógenos en cuatro (4) granjas lecheras de Estados Unidos.

\begin{tabular}{l|c|c|c|c|c}
\hline \multirow{2}{*}{ Tipo de muestra } & \multirow{2}{*}{$\begin{array}{c}\text { No. } \\
\text { muestras }\end{array}$} & $\begin{array}{c}\text { L. } \\
\text { monocytogenes }\end{array}$ & Salmonella & C. jejuni & $\begin{array}{c}\text { E. coli 0157:H7 } \\
\text { y no 0157 }\end{array}$ \\
\cline { 3 - 6 } & & 6 & 3 & 1 & 0 \\
Alimento/ensilados & 97 & 1 & 3 & 0 & 0 \\
Agua de bebida & 92 & 7 & 2 & 13 & 0 \\
Heces (mezclas) & 94 & 14 & 4 & 7 & 2 \\
Hisopado rectal en terneros & 98 & 1 & 2 & 4 & 1 \\
Hisopado rectal en vacas & 86 & 0 & 0 & 1 & 0 \\
Corrales & 4 & 13 & 6 & 5 & 0 \\
Piso/ordeño & 90 & 0 & 0 & 3 & 0 \\
Tanques de almacenamiento & 10 & 0 & 0 & 0 & 0 \\
Filtros de las líneas & 49 & 1 & 1 & 0 & 0 \\
Salas de ordeño & 24 & 0 & 0 & 0 & 0 \\
Excrementos de aves & 17 & 2 & 2 & 1 & 2 \\
Moscas & 20 & 0 & 0 & 0 & 0 \\
Ratas & 5 & 0 & 3 & 0 & 0 \\
Pájaros & 4 & 0 & 0 & 0 & 0 \\
\hline TOTAL & 1 & $45(6,5 \%)$ & $26(3,8 \%)$ & $35(5,1 \%)$ & $5(0,7 \%)$ \\
\hline
\end{tabular}

Fuente: Murinda et al.,2004 (244).

\subsubsection{Producción Primaria}

La producción primaria comienza desde la cría, levante y etapa productiva de los animales e involucra el control de enfermedades zoonóticas y no zoonóticas, y el manejo de insumos agropecuarios como medicamentos veterinarios, desinfectantes, sales mineralizadas y forrajes frescos o conservados (ensilaje, heno, henolajes, etc) (245).

La leche naturalmente puede contener células somáticas $(246,247)$, sin embargo,se ha reportado que un alto recuento de las mismas puede relacionarse con la presencia de microorganismos patógenos, siendo de especial interés $S$. aureus $(24,57)$.

Entre las principales fuentes de contaminación de la leche cruda están:

Forrajes: Los pastos frescos o mal conservados son una fuente de contaminación, ya que pueden contener microorganismos como $L$. monocytogenes, esporas de $B$. cereus y Campylobacter spp.; asimismo en pastos secos puede sobrevivir $C$. burnetii por largos periodos de tiempo $(116,206,207,246,248)$. 
El contagio del ganado bovino con L. monocytogenes es mayor en épocas de invierno y aumenta con el suministro de ensilaje de mala calidad con pH superiores a 4,5 (248-250). Un sellado deficiente de las bolsas que contienen el ensilado durante su almacenamiento, puede crear condiciones de aerobiosis que conllevan a un aumento del $\mathrm{pH}$ y la humedad favoreciendo la multiplicación de L. monocytogenes incrementando considerablemente su número (233). Algunos autores coinciden en que una ruta probable para la transmisión de $L$. monocytogenes en las granjas incluye la contaminación inicial de suelos y cultivos, heces de animales en pastoreo, otras secreciones/excreciones, consumo de agua contaminada, efluentes y abonos utilizados para fertilizar los campos $(230,233)$. La contaminación con L. monocytogenes en pastos se puede originar por la irrigación de éstos con efluentes sometidos a un tratamiento deficiente. Los abonos utilizados como fertilizantes, igualmente pueden ser un vehículo de contaminación con L. monocytogenes (10).

Heces: Un estudio realizado por Signorini et al. (2008), evaluó la presencia de los principales microorganismos en leche cruda y estableció que el hallazgo de enterobacterias en leche cruda es un indicio de contaminación con materia fecal, ya que estos tipos de microorganismos son habitantes normales de la flora intestinal. En este estudio se encontraron $1,71 \log \mathrm{UFC} / \mathrm{mL}$ de enterobacterias en muestras de leche provenientes directamente de la ubre (251).

L. monocytogenes puede llegar a la leche a través de la materia fecal que al estar diseminada en el ambiente de la granja puede contaminar el agua, piensos, suelo y pastos fertilizados con residuos fecales tratados inadecuadamente (10). Se ha comprobado una prevalencia de $L$. monocytogenes en muestras individuales de heces tomadas en distintas granjas en un rango entre 0 y $25,5 \%$, confirmando lo reportado por Skovgaard y Morgen (1988) y Nightingale et al. (2004) sobre la prevalencia de $L$. monocytogenes en heces de terneros sanos en un rango entre 3,1 y $51 \%(233,252)$. También se ha reportado presencia de $L$. monocytogenes en las heces de ganado vacuno en Europa con una variación entre el 2 y el $52 \%$ en distintos países, y sus aislamientos se han relacionado con la prevalencia en piensos (10).

El ganado vacuno es el mayor reservorio de E. coli 0157:H7. Una revisión sobre prevalencia de E. coli enterotoxigénico (ETEC) en heces de ganado vacuno demostró una contaminación variable entre 0,2 y 48,8\% (10). La excreción de E. coli enterohemorrágico (EHEC) en heces del ganado suele ser transitoria con una duración de 3 a 4 semanas (253). Otras especies como cerdos, venados y búfalos son consideradas reservorios de este microorganismo (121).

La utilización de heces bovinas como abono de pastos y cultivos es considerada un factor de riesgo debido a que son el principal reservorio de Campylobacter spp. Estos abonos también se han reportado como una fuente importante de contaminación con EHEC (254), no obstante cuando éste es sometido a procesos de compostaje se reduce su presencia (28). 
La zona del ordeño puede convertirse en fuente de contaminación cuando se acumula estiércol con microorganismos como L. monocytogenes, Salmonella spp., E. coli, C. jejuni, entre otros $(20,233,255)$. Una práctica común en las fincas es el lavado de los establos con agua para remover las heces, lo cual puede distribuir a través de todo el ambiente de la granja el microorganismo, facilitando la contaminación de otros animales (57).

Las heces de pájaros o roedores pueden contaminar los concentrados con Salmonella spp. antes de su llegada a la granja o durante su almacenamiento por deficiencias en los procesos de elaboración (10).

Agua: el agua de bebida de los animales es otra fuente de contaminación importante por Campylobacter spp., donde tiene la habilidad de permanecer viable por más de 4 semanas a $4^{\circ} \mathrm{C}$ (256). En diversos estudios se ha aislado a este microorganismo en aguas (244) y se ha establecido que es más frecuente en época de verano que en invierno (257). También se ha observado la transmisión de Campylobacter spp. desde aguas subterráneas al ganado vacuno (10). Este microorganismo presenta una versatilidad tal que es capaz de adaptarse a diversos ambientes, especialmente en el intestino de animales de sangre caliente y aves, ya que se ha demostrado que, al pasar por diferentes reservorios, magnifica su número y al estar en el medio ambiente nuevamente es ingerido por huéspedes y continua el ciclo de contaminación (20).

En el agua de bebederos en granjas han sido detectadas E. coli (21) y Salmonella spp. con una prevalencia del $0,8 \%(253,258)$. Estos microorganismos al ser entéricos pueden albergarse en el intestino del ganado convirtiéndose de esta manera en reservorios, se ha demostrado que es más frecuente la presencia de Salmonella spp. en vacas multíparas que en vacas con una sola cría (259).

\subsubsection{Rutina de Ordeño}

La rutina del ordeño incluye las etapas de despunte, limpieza y desinfección de los pezones, ordeño (manual o mecánico) y sellado de los pezones (260). En Cuba, Novoa et al. (2005) determinaron que una inadecuada rutina permite el desarrollo de mastitis bovina (261), con la consecuente contaminación de la leche con microorganismos patógenos como $S$. aureus, $E$. coli, entre otros, que afectan la inocuidad del producto.

Un estudio reciente demostró que un factor de riesgo para la presencia de $S$. aureus en esta etapa, es que no existan separaciones físicas entre el establo y la zona de ordeño; este mismo estudio señala que fincas pequeñas presentan más riesgo de obtener leches contaminadas con S. aureus, debido a fallas higiénicas (262). 
Despunte: El despunte consiste en la eliminación de los primeros chorros de leche que están en la cisterna del pezón, con el fin de barrer el canal, estimular la bajada y observar cambios macroscópicos de la leche causados por mastitis clínica, que puede contener microorganismos patógenos. La etapa del despunte permite eliminar microorganismos como $S$. aureus y $L$. monocytogenes (230, 263, 264). En fincas del altiplano cundiboyacense, Calderón et al., (2002), reportaron que la realización y evaluación del despunte disminuyó en las vacas la probabilidad de presentar mastitis clínica y subclínica en un 54\% (264), estudios similares se han realizado en otros países y corroborando la importancia de esta práctica $(255,265)$.

Limpieza y desinfección de los pezones: La limpieza y desinfección de los pezones, tiene como finalidad reducir el conteo de bacterias presentes en la piel de los pezones, entre las que se pueden encontrar B. cereus, E. coli 0157:H7, C. jejuni, Salmonella spp. provenientes del medio ambiente $(247,266)$. Otros microorganismos que contaminan la superficie de los pezones y ubres incluyen Streptococcus spp., Staphylococcus spp., bacterias formadoras de esporas y coliformes entre otras bacterias Gram negativas; pudiendo ser algunos de estos termodúricos y psicrótrofos simultáneamente, es decir, ser resistentes a la pasteurización y capaces de crecer en temperaturas de refrigeración respectivamente (15).

Estudios realizados en Estados Unidos encontraron como factor de riesgo que la falta de procesos de limpieza y desinfección de la ubre favorecen la presencia de leches contaminadas con L. monocytogenes provenientes del medio ambiente (267).

Moreno et al. (2007), determinaron que en fincas donde se practicó el secado de los pezones, se disminuyó el número de coliformes a 7,8 × 104 UFC/mL en comparación a las fincas donde

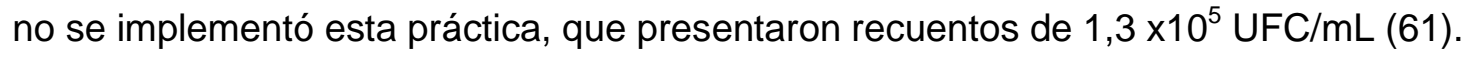

Ordeño. Durante el proceso de ordeño, los bovinos con enfermedades zoonóticas producidas por B. abortus, C. burnetii, M. bovis y esporádicamente por L. monocytogenes (36, 162, 249, 268-271), pueden excretar estos microorganismos en la leche; en el caso de los tres primeros la eliminación puede ser intermitente. En cuanto a Staphylococcus aureus, Singorini et al., mencionan que la ubre de las vacas es el sitio donde existe el mayor riesgo de contaminación por este microorganismo ya sea por la presentación de mastitis de animal o por contacto directo con las manos del operario, las cuales pueden ser fuente de contaminación (251).

En el ordeño manual, se hace necesario que el ordeñador sólo se dedique a la función de cosechar la leche (272). Calderón et al. (2009) en sistemas doble propósito de Montería (Córdoba), reportaron que cuando los operarios que ordeñan no manean o sujetan las patas de las vacas, se disminuye la probabilidad de infectar las glándulas mamarias en un $55 \%$ y por ende el riesgo de contaminar la leche (273). 
En el proceso de ordeño mecánico, el equipo utilizado puede ser responsable de introducir una gran cantidad de bacterias en la leche cruda (57) constituyéndose como una fuente de contaminación de microorganismos formadores de biopelículas ( $L$. monocytogenes, $Y$. enterocolitica, $S$. Enteritidis y $C$. jejuni) cuando el proceso de limpieza y desinfección no es eficiente. Esto se debe a que las bacterias pueden adherirse en superficies como el acero inoxidable y aumentar el riesgo de contaminación de la leche $(274,275)$.

Estudios recientes señalan que los equipos se constituyen en un reservorio importante de $L$. monocytogenes (274). Un estudio realizado en Estados Unidos encontró la presencia de Salmonella spp. y L. monocytogenes en los filtros de las líneas de conducción, sugiriendo fallas en los procesos de limpieza y desinfección (20), mientras que otros, han revelado la presencia de $S$. aureus en los equipos (263).

Sellado de los pezones: Es la aplicación de una solución desinfectante al final del ordeño con el fin de impedir el ingreso de microorganismos patógenos al interior de la ubre (276). Se ha demostrado que sellar los pezones con desinfectante permite disminuir la probabilidad de desarrollar mastitis hasta en un $65 \%(260,264,276)$. Igualmente el sellado evita la colonización de la ubre por parte de microorganismos patógenos como S. aureus, L. monocytogenes, Salmonella spp., E. coli y Campylobacter spp. $(10,263)$.

Limpieza y desinfección de equipos y utensilios: Los protocolos de limpieza y desinfección efectivos y la adecuada sustitución de materiales plásticos en el equipo de ordeño limitan el establecimiento de biopelículas y la posterior contaminación de la leche almacenada en tanques. Por otro lado, las condiciones de uso de los detergentes y desinfectantes deben seguir las indicaciones del fabricante, igualmente, es importante tener en cuenta la temperatura, $\mathrm{pH}$, concentración y tiempo de exposición; de lo contrario se dificulta la eliminación de los residuos de leche, favoreciendo la formación de biopelículas (275).

Los procesos ineficientes de limpieza y desinfección influyen en la inocuidad de la leche. El desarrollo de protocolos en bajas temperaturas o en ausencia de desinfectantes, favorecen el crecimiento de microorganismos patógenos $(15,16)$. La presencia de microorganismos formadores de biopelículas $(274,275)$ puede estar favorecida también por deficiencias en el lavado y la desinfección del equipo y los utensilios. El uso de esponjas de metal o abrasivas, rayan las superficies metálicas creando un medio ideal para el crecimiento microbiano y producción de biopelículas (245). Se demostró que la desinfección reduce en casi 4 veces, la presencia de $L$. monocytogenes en filtros de ordeño provenientes de granjas lecheras de Nueva York (267).

En otra investigación Guerreiro et al., (2005), reportaron que la leche puede ser contaminada cuando entra en contacto directo con diferentes tipos de superficies de las cantinas, equipos de ordeño y tanques de enfriamiento. Además, explicaron que el conteo total de bacterias en leche 
puede incrementarse significativamente cuando ocurre algún tipo de contacto con equipos y utensilios que no hayan tenido una adecuada limpieza y desinfección (277).

El agua utilizada para los procesos de limpieza y desinfección en la zona de ordeño, puede ser otra fuente de contaminación cuando presenta calidad microbiológica inadecuada pudiendo contener microorganismos patógenos como por ejemplo: Salmonella spp., E. coli O157:H7, L. monocytogenes y Campylobacter spp. $(256,278,279)$.

\subsubsection{Almacenamiento}

La leche cruda, por lo general, se almacena en diferentes etapas de la cadena antes de llegar al consumidor final. En finca puede almacenarse en tanques de acero inoxidable, cantinas $u$ otros recipientes $(16,38,275)$. Con el fin de extraer los cuerpos extraños antes de su almacenamiento, la leche debe ser filtrada (280), siendo ideal que el filtro sea estéril y desechable para asegurar un filtrado higiénico de la misma $(260,280)$.

El Departamento de Agricultura de Michigan establece que, con el objeto de reducir la actividad metabólica de los microorganismos patógenos y evitar su multiplicación, la leche debe ser enfriada a una temperatura de 0 a $4,4^{\circ} \mathrm{C}(281)$. Es importante señalar que a esta temperatura pueden sobrevivir y multiplicarse microorganismos psicrotróficos patógenos asociados con ETA como $L$. monocytogenes, $Y$. enterocolitica y algunas cepas de $B$. cereus $(282,283)$, por lo que se debe evitar la contaminación microbiana en las etapas anteriores. Además, Lafarge et al. concluyen en un estudio adelantado en el 2004 que las bajas temperaturas $\left(4^{\circ} \mathrm{C}\right.$ por 24 horas) aumentan algunas poblaciones bacterianas especificas como las de L. monocytogenes (243).

El tiempo de almacenamiento de la leche cruda desde el ordeño hasta consumo puede estar relacionado con el crecimiento de microorganismos patógenos. Lorenzetti (2006), observó que los recuentos de bacterias psicotrópicas aumentan cuando la leche esta en refrigeración entre $1 \mathrm{a} 6^{\circ} \mathrm{C}$. Por tanto sugiere almacenar la leche cruda lo más mínimo posible con el fin de evitar la proliferación de cualquier microorganismo patógeno que resista bajas temperaturas en leche como es el caso de Bacillus cereus (284).

Diversas investigaciones han demostrado la presencia de patógenos en los tanques de almacenamiento de la leche en las fincas, siendo $C$. jejuni, $E$. coli productor de Shiga Toxina, $L$. monocytogenes, S. aureus, $Y$. enterocolitica y Salmonella spp. los patógenos más frecuentemente encontrados. Se ha establecido que las prevalencias varían de acuerdo con la localización geográfica, temporada, tamaño de la granja, número de animales, condiciones higiénicas y prácticas de manejo $(20,27,31,38,58,255,285,286)$.

La presencia de patógenos alimentarios en los tanques de almacenamiento está ligada principalmente con la contaminación fecal que ocurre durante la recolección de la leche cruda. 
La alta frecuencia de aislamientos de Campylobacter spp. y E. coli enterohemorrágica (57) en las heces del ganado sugiere que la contaminación de los tanques de almacenamiento ocurre principalmente durante el proceso de ordeño y el almacenamiento de la leche (287), sin embargo, algunos microorganismos que causan mastitis pueden excretarse directamente en la leche y llegar al tanque contaminándolo (20).

Altos recuentos de células somáticas (RCS) en la leche de tanque de los hatos indican la incidencia de mastitis debido a una infección intramamaria (IM) causada por diferentes tipos de microorganismos entre éstos $S$. aureus que es encontrado en la mayoría de los casos en estas leches mastíticas o con altos RCS (288). Jarayao et al. 2004 (289), relacionan un alto recuento de $S$. aureus en los tanques de almacenamiento con un alto RCS .

Se ha establecido que fallas en la temperatura de los tanques de almacenamiento, así como tiempos largos antes de su procesamiento, favorece la multiplicación de los microorganismos presentes en la leche. También problemas en la limpieza y desinfección de los tanques permiten la contaminación de la leche (290). El almacenamiento prolongado de la leche antes de su procesamiento (hasta 5 días), favorece que microorganismos psicrótrofos proliferen y puedan llegar a ser predominantes en la leche cruda; es así como, a temperaturas de $7,2^{\circ} \mathrm{C}$ el crecimiento es más rápido que a temperaturas inferiores de $4,4^{\circ} \mathrm{C}$. No obstante, a pesar de que la leche sea obtenida bajo óptimas condiciones puede tener una población de psicrótrofos menor del $10 \%$ del recuento total, por lo tanto estos microorganismos pueden convertirse en la microflora dominante después de $2-3$ días a $4,4^{\circ} \mathrm{C}(15)$.

Los tanques de almacenamiento pueden ser una fuente secundaria de contaminación de la leche como lo sugieren Yoshida et al.,1998, en cuyo estudio aislaron L. monocytogenes en el tanque de almacenamiento a partir de la pared interna (2/2), pared externa (2/2), válvula de descarga (2/2), agitador (2/2), embudo (2/2) y las muestras de leche de tanque (3/3) procedentes de una de las plantas evaluadas y así mismo, en la investigación de Waak et al., 2002 (291), en la cual aislaron L. monocytogenes del 19,6\% y L. innocua en 8,5\% de las muestras de leche provenientes de silos. Kousta et al, (2010), mencionó que 11 de 215 muestras de equipos de procesamiento de leche cruda fueron positivas a Listeria monocytogenes $(5,1 \%)$ incluyendo los tanques de almacenamiento en las fincas (292).

Latorre et al. (2010) (275), menciona que la presencia de agua, residuos de alimentos y bajas temperaturas en la superficie de los tanques de almacenamiento de leche proporcionan condiciones favorables para que $L$. monocytogenes sobreviva y se multiplique; adicionalmente, las biopelículas formadas por algunas cepas sobre el acero inoxidable se convierten en una fuente potencial de contaminación de la leche. La válvula de descarga del tanque de almacenamiento es considerada una de las principales fuentes de contaminación, esto se debe a que esta zona es de difícil acceso durante la limpieza, lo cual puede permitir la acumulación de residuos de leche favoreciendo el crecimiento bacteriano (16). 


\subsubsection{Transporte, distribución y comercialización de leche cruda}

A pesar de que la contaminación de la leche cruda durante el transporte, distribución y comercialización no ha sido ampliamente documentada, Soomro et al., (2002) en Pakistán, reportó contaminación con E. coli en 13/20 (65\%) muestras comercializadas en tiendas y casas, $12 / 20$ y 10/20 comercializadas por jarreadores utilizando animales de carga como burros y bicicleta, respectivamente. Se concluyó que una posible fuente de contaminación fueron los utensilios utilizados para el transporte así como las manos sucias de los distribuidores, no se menciono si la cepa aislada era patógena (232).

En Colombia existe poca información sobre el transporte de la leche cruda, sin embargo, es bien conocido que una deficiente infraestructura de la red de frío es uno de los factores de promueven la contaminación de la leche fresca ya que frecuentemente se transporta en vehículos sin refrigeración por largos recorridos y periodos de tiempo, condiciones que favorecen el crecimiento bacteriano, muchas veces ayudado por las altas temperaturas ambientales (241).

En un estudio realizado en el 2007 en el municipio de Pamplona (Santander) a 19 rutas de leche cruda, Carrascal et al. reportaron la mezcla de hasta 40 proveedores en un solo vehículo y rutas que tardan más de 4 horas en transportar la leche hasta su destino final $(65,9 \%$ son comercializadas sin pasteurización). De este estudio, los autores destacan que la incidencia de L. monocytogenes $(5,5 \%)$ es favorecida por factores como tiempos de transporte prolongados (>4 horas) y deficiencias en el sistema de refrigeración durante el mismo (66, 69, 270). Albarracin et al. mencionan que los vehículos utilizados para la entrega de leche no incluye carrotanques isotérmicos pero si camperos $(1,7 \%)$, camiones $(21 \%)$, buses $(17,6 \%)$ y otros $(30,3 \%)$. En cuanto al transporte en buses los autores describen que también son transportados allí pasajeros y carga (293).

En Bogotá se llevó a cabo un estudio sobre las alternativas económicas, tecnológicas, logísticas, organizacionales y sociales de productores, comercializadores y consumidores de leche cruda el cual refiere que existen cerca de 441 jarreadores y 300.000 consumidores en el Distrito Capital. Se mencionan, además, diferentes medios de transporte de la leche cruda como: triciclo $(50,7 \%)$, camioneta $(16,4 \%)$, carro esferado $(4,5 \%)$ y otros $(28,4 \%)(294)$.

\subsubsection{Centro de Acopio/Plantas de Enfriamiento}

La leche procedente de hatos puede ser recolectada y almacenada en tanques de frío en establecimientos denominados centros de acopio y/o plantas de enfriamiento con el fin de 
someterla a un proceso de enfriamiento (2) y luego comercializarla para consumo directo o para plantas de procesamiento.

Un estudio realizado en Malasia evidenció diferencias significativas en el recuento de $S$. aureus en tanques de acopio, donde se encontró que las diferencias se presentaban en el tipo de ordeño empleado, no obstante estos autores no hacen mención a las diferencia en los procesos de ordeño. Con relación a $L$. monocytogenes el estudio estableció además, que existen diferencias en la prevalencia de este patógeno en los centros de acopio, asociado a factores climáticos(57).

Un estudio realizado en Canadá en plantas de productos lácteos, logró identificar que la principal fuente de contaminación por $S$. aureus era el ingreso al establecimiento de leche cruda contaminada con este patógeno (295).

\subsubsection{Manipulador}

Según el Decreto 3075 de 1997 del Ministerio de Salud (4), el manipulador es "toda persona que interviene directamente y, aunque sea en forma ocasional, en actividades de fabricación, procesamiento, preparación, envase, almacenamiento, transporte y expendio de alimentos". Los manipuladores enfermos o con algún tipo de infección que estén en contacto directo con los equipos y materiales utilizados en el transporte de la leche se convierten en fuentes potenciales de contaminación (10).

Las manos de los ordeñadores son fuentes potenciales de $S$. aureus y $E$. coli cuando no se practican adecuadas medidas de higiene $(10,21,230,247)$. $S$. aureus puede contaminar la leche cruda a través de las manos de los operarios (296). La contaminación de la leche con S.aureus proveniente de manipuladores se ha reportado por otros estudios donde se identificó a éstos como fuentes portadoras del microorganismo en la piel y en las fosas nasales (297). En otros estudios se ha reportado que las manos de los ordeñadores son fómites (objeto capaz de llevar un microorganismo y transferirlo de un cuerpo a otro) que propagan $S$. aureus en los hatos lecheros (298).

Tondo et al., 2000 (295), encontraron que el 90,4\% (19/21) de las muestras de leche presentaban contaminación con $S$. aureus, adicionalmente el 32\% (19/51) de los manipuladores de esta leche fueron portadores asintomáticos de $S$. aureus. En el mismo estudio se encontró que los productos finales obtenidos a partir de estas leches contenían $S$. aureus y los manipuladores fueron una potencial fuente de contaminación ya que una de las cepas aisladas de los productos fue similar a la aislada de los manipuladores. Kousta et al. reportó que los trabajadores en fincas y plantas procesadoras pueden ser responsables de transportar y 
dispersar L. monocytogenes, contaminando de esta manera utensilios, equipos de ordeño y los tanques de almacenamiento de la leche (292).

En 1982 en Canadá, se reportó un brote de Campylobacter spp. debido al consumo de leche sin pasteurizar, esta leche había sido manipulada por tres personas a las cuales se les aisló el microorganismo, pero el reporte concluyó que, aunque los manipuladores fueron una potencial fuente de contaminación, probablemente no fueron la causa principal del brote (299).

Por otro lado, se han realizado estudios en los cuales hatos lecheros con bajos recuentos de células somáticas (RCS) en leche $(<150.000 \mathrm{cel} / \mathrm{mL})$ se han relacionado con un manejo limpio y correcto siguiendo buenas prácticas durante la rutina de ordeño. En estos hatos los manipuladores de la leche contaban con conocimiento acerca de la importancia de un manejo adecuado para disminuir la incidencia de las infecciones intramamarias (IM) en los animales. En contraste, hatos con altos RCS en leche (>400.000 cel/mL) contaban con personal poco capacitado y poco conocimiento de la importancia de la higiene y buenas prácticas ganaderas en la producción de leche (300-302). La Unión Europea establece que leches con RCS superior a $400.000 \mathrm{cel} / \mathrm{mL}$ son inadecuadas para ser consumidas (302).

Dufour et al. (2011) (303), reporta que el uso de guantes por parte del personal puede disminuir la incidencia de mastitis en los hatos lecheros, así como bajar el RCS de la leche de tanque, por lo que recomiendan que los ordeñadores usen guantes durante el ordeño.

El decreto 616 del MPS (2), indica que el personal relacionado con la producción y recolección de la leche, debe recibir capacitación continua en prácticas higiénicas en la manipulación de la leche, higiene personal, hábitos higiénicos y responsabilidad del manipulador. Además, menciona que la manipulación de la leche debe ser lo menos posible a lo largo de toda la cadena productiva. A su vez, el Decreto 1880 de 2011 (3), indica que los manipuladores deben tener constancia de capacitación en manejo higiénico de alimentos.

\subsubsection{LEGISLACIÓN INTERNACIONAL DE VENTA DE LECHE CRUDA}

La leche cruda se produce y comercializa en gran parte de los países del mundo (Ver anexo 1) $(241,304)$. En países como India y Nueva Zelanda es legal la comercialización de leche cruda para consumo humano directo (21), así como en Inglaterra y Gales donde se exige un etiquetado que informe que es un producto que no debe ser consumido por niños, mujeres embarazadas, ancianos ni personas enfermas (305) (Ver anexo 1).

En la misma forma, en veintiocho (28) estados de los Estados Unidos se comercializa leche cruda, donde los consumidores pueden comprarla en tiendas y puntos de distribución (306); los 
estados que permiten su venta presentan más brotes de enfermedades relacionadas con dicho consumo que los estados donde se prohíbe la venta de este producto (307). En 1938, antes de la adopción generalizada de la pasteurización de la leche en los Estados Unidos, se estimó que el $25 \%$ de los brotes transmitidos por los alimentos y agua, se asociaron con leche cruda (sin pasteurizar). En 2001, el porcentaje de brotes asociados con leche cruda fue menor del $1 \%$ (308).

En algunos países de Europa como Alemania, Holanda, Bélgica, Suiza, Francia, Dinamarca y Suecia, es legal la comercialización de leche cruda para consumo humano directo. Sin embargo, los agricultores que venden este producto, deben pasar por inspecciones más estrictas que los que venden leche para pasteurizar (309).

Por el contrario en Canadá, la ley federal prohíbe la venta o donación de leche cruda con sanciones de 250.000 dólares y hasta 3 años de cárcel. Igualmente, en Japón y Australia es prohibida la comercialización de leche cruda $(309,310)$. 


\section{CONCLUSIONES}

a. Los microorganismos patógenos más importantes aislados de leche cruda son Brucella spp., M. bovis, L. monocytogenes, S. aureus, E. coli, Salmonella spp., C. jejuni, C. burnetii, $B$. cereus y $Y$. enterocolitica.

b. Los brotes o casos de ETA en humanos producidos por el consumo de leche cruda están relacionados principalmente con L. monocytogenes, S. aureus, E. coli 0157:H7, Salmonella spp. y C. jejuni.

c. Las dosis infectivas mínimas de los microorganismos implicados en brotes o casos relacionados con el consumo de leche cruda son: para Brucella spp. $10-100 \mathrm{UFC} / \mathrm{mL}$ (164). L. monocytogenes menor de $1.000 \mathrm{UFC} / \mathrm{mL}$ de alimento (179). Para S. aureus se necesitan recuentos entre 105 y $106 \mathrm{UFC} / \mathrm{mL}$ para que se produzca la toxina $(200,211)$ y la dosis de toxina requerida para inducir los síntomas de la intoxicación estafilocócica alimentaria (SPF) en humanos esta alrededor de $0,1 \mu \mathrm{g}$, aunque se han reportado estudios que indican que la dosis para un adulto puede estar entre 10 y $20 \mu \mathrm{g}$ (121). Para Salmonella spp. la dosis infectiva es de 15 a $20 \mathrm{UFC} / \mathrm{mL}$ (121). Para Campylobacter spp. estudios sugieren que recuentos entre $4 \times 10^{2}$ y $5 \times 10^{2} \mathrm{UFC} / \mathrm{mL}$ pueden causar enfermedad; otros estudios consideran la dosis infectiva entre $5 \times 10^{2}$ y $8 \times 10^{2} \mathrm{UFC} / \mathrm{mL}$ (165). Para E. coli enterotoxigénico (ETEC) se han reportado dosis infectivas de 108 UFC/mL y menos de 10 células para $E$. coli enterohemorrágico (129). La dosis infectiva de Brucella spp. está entre 10 y 100 UFC/mL (164).

d. Las fuentes de contaminación de la leche con microorganismos patógenos como $L$. monocytogenes, S. aureus, E. coli, Salmonella spp., C. jejuni, entre otros, pueden ser de origen exógeno provenientes de operarios, suelo, agua, piel de las vacas, heces, equipos de ordeño, equipos y utensilios con deficientes medidas higiénicas y tanques de almacenamiento y transporte, y su presencia en la leche está relacionada con deficiencias en las Buenas Prácticas Ganaderas.

e. Las fuentes de contaminación de la leche con microorganismos patógenos como $B$. abortus, $C$. burnetii, $M$. bovis y esporádicamente por $L$. monocytogenes pueden ser de origen endógeno provenientes de enfermedades zoonóticas.

\section{f. Medidas de Prevención}

\section{Aplicables a lo largo de toda la cadena}

a. Garantizar la cadena de frío de la leche cruda durante las etapas de recolección, transporte y almacenamiento, con el fin de controlar el crecimiento de microorganismos como E. coli, Salmonella spp., $S$. aureus, $B$ cereus, que puedan estar presentes en la leche. La temperatura deberá ser inferior a $4^{\circ} \mathrm{C}$. Se debe tener en cuenta que en el caso de $L$. monocytogenes la refrigeración no inhibe el crecimiento. 
a. El agua utilizada para los procesos de limpieza y desinfección durante las etapas de ordeño, almacenamiento y transporte, debería estar libre de patógenos como Brucella spp., Campylobacter spp., Escherichia coli, L. monocytogenes, Salmonella spp., Staphylococcus aureus y Yersinia enterocolitica. Debe evitarse el uso de aguas crudas o recicladas sin tratamiento previo.

b. Implementar programas de limpieza y desinfección que contemplen los tiempos de exposición de los desinfectantes y su concentración; se deberá seguir las instrucciones de las casas comerciales de tal manera que se reduzca el riesgo por prácticas inadecuadas en el manejo de estas sustancias, el programa deberá incluir el cómo y cuándo debe realizarse este proceso en las zonas de ordeño, almacenamiento y distribución de la leche. Se debe hacer énfasis en los utensilios, equipos de ordeño, tanques de refrigeración y todas las superficies que se encuentren en contacto con el producto.

c. Generar y mantener registros de trazabilidad de la leche cruda que le permitan al consumidor conocer la procedencia del producto y que esté disponible para la autoridad competente.

d. Implementar programas de educación y sensibilización que involucre a los productores y comercializadores que den a conocer los riesgos de consumir leche cruda y los peligros asociados a ésta.

e. Implementar programas de capacitación y sensibilización para los manipuladores que se enfatice en las medidas de higiene necesarias para reducir el riesgo potencial de contaminación del producto por su manipulación.

\section{Aplicables en la producción primaria}

b. Enfriar la leche en el menor tiempo posible.

c. Promover la obtención de la leche en condiciones higiénicas, y que proceda de animales sanos.

d. Intensificar las medidas de control, en función de las BPG, durante la época de lluvias, ya que el exceso de humedad del suelo propende la suciedad de las ubres y por ende la contaminación con microorganismos pagotenos tales como Bacillus cereus, Brucella spp., Campylobacter spp., Escherichia coli, L. monocytogenes, Salmonella spp., Staphylococcus aureus y Yersinia enterocolitica.

e. Implementar programas de capacitación a los inspectores de las autoridades sanitarias competentes para que éstos, a su vez, sensibilicen a los productores y comercializadores sobre los posibles peligros presentes en la leche cruda.

f. El agua utilizada en los abrevaderos debería estar libre de patógenos como Brucella spp., Campylobacter spp., Escherichia coli, Listeria monocytogenes, Salmonella spp., Staphylococcus aureus y Yersinia enterocolitica. Debe evitarse el uso de aguas crudas o recicladas sin tratamiento previo. 
g. Realizar un adecuado manejo de excretas que incluya su retiro de zonas de pastoreo, ordeño y almacenamiento de la leche. En el caso de utilizar abonos orgánicos para la fertilización de los pastos, debe garantizarse la ausencia de microorganismos patógenos.

h. Las instalaciones destinadas para la obtención de leche bovina deben evitar la contaminación cruzada.

i. Contar con áreas separadas del ordeño, para el almacenamiento de la leche cruda, las cuales deberán ser de fácil limpieza y desinfección, con ventilación adecuada y libre de otros animales y plagas.

j. Contar con programas de prevención y control de plagas implementados.

k. Los equipos y utensilios para el ordeño deben construirse en materiales sanitarios y fáciles de desarmar y limpiar.

I. En el caso de ordeño manual usar filtros desechables o plásticos previamente lavados y desinfectados, se debe evitar el uso de filtros de tela.

m. En el caso de vacas mastíticas estas deberán ordeñarse al final de la jornada de ordeño para evitar el contagio de vacas sanas. Eliminar la leche que proceda de animales enfermos o vacas tratadas, evitando su consumo o uso para alimentación de terneros.

n. En las zonas de ordeño deben evitarse los encharcamientos, las mangueras deben estar recogidas y después de su uso deben desocuparse completamente.

o. Se debe evitar la formación de biopelículas en los equipos y utensilios (son menos propensos los de acero inoxidable). La aplicación de limpieza mecánica reduce la formación de biopelículas.

\section{Transporte}

a. Transportar la leche garantizando la temperatura de frío y en los casos en que no sea posible, transportarla en el menor tiempo posible a su lugar de destino.

b. Utilizar equipos, utensilios y tanques de enfriamiento fabricados en materiales sanitarios y de fácil limpieza y desinfección. Debe evitarse el uso de recipientes plásticos que hayan sido utilizados para transportar otro tipo de productos.

c. Reducción en los tiempos de entrega con el fin de evitar la multiplicación microbiana y la posible introducción de nuevos contaminantes al producto.

\section{Centros de Acopio o Plantas de Enfriamiento}

a. Implementar programas de limpieza y desinfección con el fin de reducir el riesgo de patógenos que pueden ingresar como $B$. cereus, $E$. coli enterohemorragico, $L$. monocytogenes, Salmonella spp, S. aureus y $Y$. enterocolitica.

b. Monitorear el correcto funcionamiento de la cadena de frío

c. Los centros de acopio deben cumplir con BPM, donde se incluya un diseño adecuado de la planta.

\section{Comercialización y Distribución}


a. Promover prácticas de manejo y conservación de la leche que incluya la cadena de frio desde el ordeño hasta el consumidor final. Es necesario aclarar que existe evidencia científica de que a una temperatura de $4,4{ }^{\circ} \mathrm{C}$ pueden sobrevivir y multiplicarse microorganismos psicrotróficos patógenos asociados con ETA como L. monocytogenes, $Y$. enterocolitica y algunas cepas de B. cereus, por lo que se debe evitar la contaminación microbiana en las etapas anteriores.

b. Los países que permiten la comercialización de leche cruda para consumo humano directo, restringen los volúmenes de venta a los consumidores y solo la permiten a aquellos productores que cumplan con los requisitos establecidos para tal fin en cada legislación (Ver Anexo 1).

c. Capacitar a los distribuidores sobre el manejo de la leche cruda para consumo humano directo.

d. Adelantar campañas de concientización sobre el almacenamiento de leche cruda, ya que un periodo prolongado antes de su procesamiento (hasta 5 días), favorece que microorganismos psicrótrofos proliferen y puedan llegar a ser predominantes en el alimento; es así como a pesar de que la leche sea obtenida bajo óptimas condiciones puede tener una población de psicrótrofos menor del 10\% del recuento total, por lo tanto estos microorganismos pueden convertirse en la microflora dominante después de 2-3 días a $4,4^{\circ} \mathrm{C}(15)$. 


\section{RECOMENDACIÓNES}

a. En base a los estudios de ocurrencia internacional, y la poca información del país, se recomienda realizar estudios de ocurrencia que deberán contar con un diseño robusto, métodos de análisis validados y sistemas de muestreo que permitan cuantificar los peligros microbiológicos comenzando con:

$\checkmark$ Brucella abortus:

Realizar estudios para identificar $B$. abortus en leche cruda de expendios y jarreadores, en el departamento de Cauca, el cual presentó positividad para Brucelosis en 2011 (311); y en un departamento que no presente positividad (Por ejemplo: Boyacá o Santander).

$\checkmark$ B. cereus

Con relación a la morbilidad por $B$. cereus (Toxina Entérica y Emética) se desconoce la verdadera incidencia de dicho evento, ya que al no ser de notificación obligatoria genera un subregistro importante.

$\checkmark$ Campylobacter spp.:

Realizar un estudio piloto para identificar Campylobacter spp. en leche cruda en la producción primaria y proveniente de expendios y jarreadores, en el departamento de Cundinamarca, el cual es el mayor productor de leche en Colombia y cuenta con el mayor número de plantas avícolas.

$\checkmark \quad$ E. coliO157:H7:

Realizar estudios para identificar y cuantificar E. coli O157:H7 en leche en la producción primaria y en los intermediarios en los departamentos de mayor producción lechera del País.

$\checkmark$ Listeria monocytogenes:

Realizar estudios para identificar, cuantificar y serotipificar L. monocytogenes en leche en expendios y jarreadores en los departamentos de mayor producción lechera del País y que posean pisos térmicos opuestos.

$\checkmark$ Samonella spp.:

Realizar un estudio piloto para identificar, cuantificar y serotipificar Salmonella spp. en leche cruda en la producción primaria y proveniente de expendios y jarreadores, en el departamento de Cundinamarca, el cual es el mayor productor de leche en Colombia y cuenta con el mayor número de plantas avícolas. 
$\checkmark$ Staphyloccus aureus:

Realizar estudios para identificar y cuantificar $S$. aureus en leche en expendios y jarreadores en los departamentos de mayor producción lechera del País.

En Colombia no se dispone de índices de hospitalización por $S$. aureus, aún cuando este patógeno es considerado como la tercera causa en el mundo de enfermedades transmitidas por alimentos.

$\checkmark$ Realizar un estudio de prevalencia de mastitis en Colombia en el cual se identifique el (s) microorganismo (s) causales.

b. Adelantar ensayos de presencia/ausencia y recuentos de bacterias patógenas, como mínimo E. coli, L. monocytogenes, Salmonella spp. y Campylobacter spp., a diferentes tiempos y temperaturas que permitan establecer los parámetros óptimos de conservación, almacenamiento y transporte de la leche cruda en Colombia.

c. EI MPS y el MADR deberían revisar y actualizar la normativa para los contaminantes microbiológicos enfocando los esfuerzos nacionales a inocuidad y no a calidad.

d. Fortalecer el Sistema de Vigilancia en Salud Pública (SIVIGILA) del país implementando estrategias que aseguren la notificación de los casos y brotes de intoxicación e infección alimentaria, de tal manera que se cuente con los datos nacionales para el monitoreo y control de las enfermedades causadas por los microorganismos descritos en el presente documento.

e. Para realizar adecuadas evaluaciones se requiere contar con datos de ocurrencia de los contaminantes microbiológicos y para evitar la duplicación de esfuerzos y recursos se solicitará a la industria, a la academia, organismos estatales y otras entidades privadas información existente sobre el tema. Para ello, la UERIA redactará procedimientos e instrumentos para unificar la recolección de la información.

Las vías para recopilar información que se proponen, asegurando la confidencialidad cuando sea requerida, son:

- Industria: Gremios, cámaras, asociaciones

- Academia: universidades, centros de investigación

- Colciencias, Comité Nacional del Codex Alimentarius de Colombia

$\checkmark$ Para la realización de los estudios propuestos, se deben proveer recursos y entre los mecanismos a considerar se debería incluir priorizaciones a nivel de investigación tanto, por parte de la academia como por los otros actores de la cadena láctea. 
$\checkmark$ Se debe además contar con datos de consumo de leche cruda como la estimación de cuántas personas la consumen, en qué cantidad y cuáles son las poblaciones con mayor frecuencia de consumo en Colombia.

$\checkmark$ Para complementar los estudios de evaluación de riesgos, es necesario contar con la información referente a los diferentes canales de comercialización y distribución de leche cruda en Colombia que incluya variables como regiones geográficas, las condiciones climáticas de las zonas productoras, los medios de transporte utilizados, temperatura y tiempos de transporte y almacenamiento, entre otros.

$\checkmark$ Fortalecer la capacidad técnica de los laboratorios de las autoridades competentes para el monitoreo de los peligros biológicos como Brucella spp., L. monocytogenes, $S$. aureus, E. coli, Salmonella spp., C. jejuni y B. cereus incluyendo su serotipificación.

$\checkmark$ Las información generada por los programas y planes de monitoreo, vigilancia y control debería ser recopilado por un sistema único de información al cual tengan acceso las entidades competentes para la toma de decisiones en tiempo real. 


\section{GLOSARIO}

ACTIVIDAD DE AGUA: Indica la fracción del contenido de humedad total de un producto que está libre, y en consecuencia, disponible para el crecimiento de los microorganismos y para que se puedan llevar a cabo diversas reacciones bioquímicas que afectan su estabilidad. Tiene un valor máximo de 1 y un mínimo de 0; cuanto menor sea este valor, mejor se conservará el producto y se expresa como $a_{w}$.

AGUA CRUDA: E aquella que no ha sido sometida a ningún proceso de tratamiento.

BACTERIA AEROBIA: Bacteria que requiere de oxigeno para su crecimiento.

BACTERIAS PSICROTRÓFAS: Microorganismos que crecen a una temperatura de $0^{\circ} \mathrm{C}$ con óptimo crecimiento entre 20 y $30^{\circ} \mathrm{C}$.

BACTERIAS MESÓFILAS: Bacterias con temperatura óptima de crecimiento entre 20 y 40 grados centígrados.

BACTERIAS TERMÓFILAS: Bacterias con temperatura óptima de crecimiento entre 40 y 80 grados centígrados.

BACTERIAS TERMODÚRICAS: Bacterias que soportan temperaturas mayores de 40 grados centígrados.

BIOPELíCULA O BIOFILM: Es un ecosistema microbiano organizado, conformado por uno o varios microorganismos asociados a una superficie viva o inerte, con características funcionales

BROTE DE ETA: Episodio en donde dos o más personas presentan una enfermedad similar después de ingerir un alimento, incluida el agua y donde la evidencia epidemiológica o el análisis de laboratorio implica a los alimentos y/o agua como vehículos de la misma

CASO DE ETA: Ocurre cuando una persona enferma, después del consumo de alimentos y/o agua contaminados.

CISTERNA: Espacio que recoge o almacena la leche dentro de los pezones o de la glándula mamaria.

CONTAMINACIÓN CRUZADA: Transferencia a un alimento de microorganismos (virus, bacterias, etc.) y compuestos químicos desde materias primas, superficies u otros alimentos. 
ENTEROTOXINA: Sustancia exógenas producida por ciertas cepas bacterianas en la etapa de crecimiento que colonizan el tracto gastrointestinal por medio de los alimentos y causan anormalidades o enfermedades.

Enterobacteriaceae: Familia de bacterias Gram negativas que contiene más de 30 géneros y más de 100 especies, pueden tener morfología de bacilos dentro de los cuales se incluyen los coliformes.

EPITELIO: Capa superficial de células que cubren el interior o exterior de una superficie corporal

GLÁNDULA MAMARIA O UBRE. Glándula productora de leche presente en las hembras de los mamíferos, consistente en lóbulos que contienen lobulillos y estos a los alveolos, con una cisterna de conducción de la leche hacia la cisterna de la glándula y la cisterna del pezón. Generalmente se encuentra en pares y comienza su secreción cuando paren y nacen sus crías. En la vaca a cada glándula mamaria se le conoce también como cuarto o cuarto mamario.

INCIDENCIA: Es el número de casos nuevos de una enfermedad en una población determinada y en un período determinado.

INTOXICACIÓN ALIMENTARIA: Es la manifestación clínica de una toxicidad debido a la exposición de sustancias tóxicas vehiculizadas en los alimentos.

PERÍODO DE INCUBACIÓN: Tiempo necesario de un microorganismo para crecer y producir una enfermedad.

INFECCIÓN: Es un término clínico que permite describir la entrada, colonización, multiplicación de un microorganismo patógeno al interior de un ser vivo y que es capaz de provocar la aparición de síntomas.

INFLAMACIÓN: Es la respuesta del sistema inmunológico a invasores extraños como virus, bacterias con el fin de neutralizar o eliminar al microorganismo y restablecer la funcionalidad del tejido u órgano.

LÁBIL: Susceptibilidad de ser destruida con cierta facilidad.

LECHE TERMIZADA: Producto obtenido al someter la leche cruda a un tratamiento térmico con el objeto de reducir el número de microorganismos presentes y permitir un almacenamiento más prolongado antes de someterla elaboración posterior.

MASTITIS: Inflamación de la glándula mamaria, generalmente producida por microorganismos patógenos o ambientales.

ORDEÑO: Es el proceso por el cual se obtiene la leche, bien sea en forma manual o por medio de un equipo de ordeño.

PATÓGENO: Microorganismo capaz de producir una enfermedad.

PREVALENCIA: Porcentaje de enfermos o infectados en un determinado tiempo. 
SISTEMA DE ORDEÑO: Instalación compuesta por varias secciones, cuyo objetivo es la obtención de la leche por medios manuales o mecánicos.

TERMIZACIÓN: Tratamiento térmico al que se somete la leche cruda, con el objeto de reducir el número de microorganismos presentes en la misma y permitir un almacenamiento más prolongado antes de someterla a elaboración ulterior. Las condiciones de la termización son de mínimo $62^{\circ} \mathrm{C}$ durante 15 a 20 segundos, seguido de enfriamiento inmediato hasta temperatura de refrigeración. La leche termizada debe reaccionar positivamente a la prueba de fosfatasa alcalina, siendo prohibida su comercialización para consumo humano directo. La termización no reemplaza la pasteurización.

VIRULENCIA: Grado de patogenicidad de un microorganismo o el potencial de gravedad de la enfermedad causada por él. 


\section{SIGLAS}

$\begin{array}{ll}\text { BPA: } & \text { Buenas Prácticas de Agrícolas } \\ \text { BPG: } & \text { Buenas Prácticas de Ganaderas } \\ \text { BPM: } & \text { Buenas Prácticas de Manufactura } \\ \text { CDC: } & \text { Centro de Control de Enfermedades } \\ \text { DAEC: } & \text { E. coli de adherencia difusa } \\ \text { DTS: } & \text { Direcciones Territoriales de Salud } \\ \text { EAEC: } & \text { E. coli enteroagregante } \\ \text { EHEC: } & \text { E. coli enterohemorrágica } \\ \text { EIEC: } & \text { E. coli enteroinvasiva } \\ \text { ENSIN: } & \text { Encuesta Nacional de la Situación Nutricional en Colombia } \\ \text { EPEC: } & \text { E. coli enteropatógena } \\ \text { ETA: } & \text { Enfermedad Transmitida por los Alimentos } \\ \text { ETEC: } & \quad \text { E. coli enterotoxigénica } \\ \text { FDA: } & \text { Agencia de Medicamentos y Alimentos de los EEUU } \\ \text { HBL: } & \text { Hemolisina BL } \\ \text { ICBF: } & \text { Instituto Colombiano de Bienestar Familiar } \\ \text { IM: } & \text { Infecciones intramamarias } \\ \text { INS: } & \text { Instituto Nacional de Salud } \\ \text { INVIMA: } & \text { Instituto Nacional de Vigilancia de Medicamentos y Alimentos } \\ \text { IVS: } & \text { Inspección, Vigilancia y Control } \\ \text { LPS: } & \text { Lipopolisacarido } \\ \text { MADR: } & \text { Ministerio de Agricultura y Desarrollo Rural } \\ \text { MPS: } & \text { Ministerio de la Protección Social } \\ \text { NZFSA: } & \text { Agencia de Seguridad Alimentaria de Nueva Zelanda } \\ \text { OMS: } & \text { Organización Mundial de la Salud } \\ \text { OPS: } & \text { Organización Panamericana de la Salud } \\ \text { RCS: } & \text { Recuentos de células somáticas } \\ \text { SIVIGILA: } & \text { Sistema Nacional de Vigilancia en Salud Pública } \\ \text { SNC: } & \text { Sistema Nervioso Central } \\ \text { STEC: } & \quad \text { E. coli productor de Shiga Toxina } \\ \text { UFC: } & \text { Unidad Formadora de Colonia } \\ \text { UPS: } & \text { Unidad de Seguimiento de Precios } \\ \text { VTEC: } & \quad \text { E. coli productor de Verotoxina } \\ & \quad\end{array}$




\section{AGRADECIMIENTOS}

La Unidad de Evaluación de Riesgo para la Inocuidad de los Alimentos UERIA del Instituto Nacional de Salud y el Ministerio de la Protección Social agradecen a todos aquellos que con su tiempo y experiencia han contribuido en la elaboración del documento denominado EVALUACIÓN DE RIESGOS BIOLÓGICOS EN LECHE CRUDA PARA CONSUMO DIRECTO, a través de la búsqueda de información científica, su análisis y observaciones.

La UERIA reconoce la colaboración y aportes de la Comisión intersectorial de Medidas Sanitarias y fitosanitarias a través de su Secretaría Técnica a cargo del Departamento Nacional de Planeación quienes contribuyeron desinteresada y oportunamente a este proceso mediante su apoyo en la búsqueda de información y como agente facilitador de la interacción con los actores del Sistema Nacional de Medidas Sanitarias y Fitosanitarias.

Así mismo a los representantes del Instituto Nacional de Salud (INS), Instituto Colombiano Agropecuario (ICA), Instituto Nacional de Vigilancia de Medicamentos y Alimentos (INVIMA), Ministerio de Agricultura y Desarrollo Rural (MADR) y a las Entidades Territoriales de Salud (DTS) que contribuyeron con información, experiencia y conocimientos específicos en el desarrollo de este trabajo. 


\section{BIBLIOGRAFÍA}

1. ICBF. Instituto Colombiano de Bienestar Familiar de Colombia. Encuesta Nacional de la Situación Nutricional en Colombia (ENSIN) 2010. 2. MPS. Ministerio de la protección social de Colombia. Decreto No. 616. 28 de Febrero de 2006 . Reglamento técnico sobre los requisitos que debe cumplir la leche para consumo humano que se obtenga, procese, envase, transporte, comercializa, expenda, importe o exporte en el país.

3. MPS/MADR. Ministerio de la Protección Social/Ministerio de Agricultura y Desarrollo Rural de Colombia. Decreto 1880 de 2011 "Por el cual se señalan los requisitos para la comercialización de leche cruda para consumo humano directo en el territorio nacional"

4. MS. Ministerio de Salud de Colombia. Decreto 3075 de 1997 "Por el cual se reglamenta parcialmente la Ley 09 de 1979 y se dictan otras disposiciones".

5. INS. (Instituto Nacional de Salud). Protocolo de vigilancia de Enfermedades Transmitidas por Alimentos ETA. Colombia. 2010.

6. ICBF. Instituto Colombiano de Bienestar Familiar. Encuesta Nacional de la Situación Nutricional en Colombia (ENSIN), 2005. Disponible en: http://scp.com.co/ArchivosSCP/ENSIN I CBF 2005.pdf.

7. MADR/CCI. Ministerio de Agricultura y Desarrollo Rural/Coorporación Colombiana Internacional. Encuesta Nacional Agropecuaria (ENA) 2009.
8. MADR/CCI. Ministerio de Agricultura y Desarrollo Rural/Coorporación Colombiana Internacional. Encuesta Nacional Agropecuaria (ENA) 2010.

9. Weir E, Mitchell J, Reballato S, Fortuna D. Public Health: Raw milk and the protection of public health. CMAJ: Can Med Assoc J. 2007;177(7):721.

10. FSANZ. (Food Standards Australia New Zealand). A Risk Profile of Dairy Products in Australia.2006. Disponible en: www.foodstandards.gov.au/ srcfiles/P2 96\%20Dairy\%20PPPS\%20FAR\%20Atta ch\%202\%20FINAL\%20-\%20mr.pdf. Consulta Febrero 2011.

11. Walstra P. Dairy technology: principles of milk properties and processes: Marcel Dekker Inc; 1999.

12. CDC. Outbreakof Listeria monocytogenes Infections Associated With Pasteurized Milk From a Local Dairy-Massachusetts, 2007 MMWR. MMWR. 2008;57:1097-100.

13. CDC. Centers for Disease Control and Prevention. Escherichia coli 0157:H7 infections in children associated with raw milk and raw colostrum from cows--California, 2006. MMWR 2008;57(23):625-8.

14. CDC. Centers for Disease Control and Prevention. Outbreak of multidrug-resistant Salmonella enterica serotype Newport infections associated with consumption of unpasteurized Mexican-style aged cheese--Illinois, March 2006-April 2007. MMWR 2008;57(16):432-5.

15. Murphy S, Boor K. Sources and causes of high bacteria counts in raw 
milk: an abbreviated review. Dairy, Food and Environmental Sanitation. 2000;20(8):1-4.

16. Elmoslemany A, Keefe G, Dohoo I, Jayarao B. Risk factors for bacteriological quality of bulk tank milk in Prince Edward Island dairy herds. Part 2: Bacteria count-specific risk factors. J Dairy Sci. 2009;92(6):2644-52. 17. Brisabois $A$, Lafarge $V$, Brouillaud A, de Buyser M, Collette C, Garin-Bastuji B, Thorel M. Pathogenic organisms in milk and milk products: the situation in France and in Europe. Revue scientifique et technique 1997;16(2):452 .

18. MPS. Ministerio de la protección social de Colombia. Decreto No. 2838 del 24 de Agosto 2006. Por el cual se modifica parcialmente el decreto 616 de 2006 y se dictan otras disposiciones.

19. Ministerio de Agricultura y Desarrollo Rural. Unidad de Seguimiento de Precios (USP): Reporte sobre precio de la leche. 2010.

20. Oliver S, Jayarao B, Almeida R. Foodborne pathogens in milk and the dairy farm environment: food safety and public health implications. Foodborne Pathog Dis. 2005;2(2):115-29.

21. NZFSA. New Zealand Food Safety Authority . Consideration of on a farm provisions for raw milk production. 29p. 2008.

22. Bothwell P. Brucellosis in children. Archives of disease in childhood. 1962:628-39.

23. Leedom J. Milk of nonhuman origin and infectious diseases in humans. Clinical infectious diseases: an official publication of the Infectious Diseases Society of America. 2006;43(5):610.

24. Oliver S, Boor K, Murphy S, Murinda S. Food Safety Hazards Associated with Consumption of Raw Milk. Foodborne Pathog Dis. 2009;6(7).

25. ICMSF. (International Commission on Microbiological
Specifications for Foods). Microorganismos de los Alimentos: Análisis microbiológico en la gestión de la seguridad alimentaria. Editorial Acribia. 2004;Zaragoza(España):367p.

26. Jayarao B. A study on the prevalence of pathogens in bulk tank milk. En: Natl Mastitis Counc. 1999:Pp. 148-9.

27. Rohrbach B, Draughon $F$, Davidson P, Oliver S. Prevalence of Listeria monocytogenes, Campylobacter jejuni, Yersinia enterocolitica, and Salmonella in bulk tank milk: risk factors and risk of human exposure. J Food Prot. 1992;52(2):9397.

28. Murinda S, Nguyen L, Ivey S, Gillespie B, Almeida R, Draughon F, Oliver S. Molecular characterization of Salmonella spp. isolated from bulk tank milk and cull dairy cow fecal samples. $J$ Food Prot. 2002;65(7):1100-5.

29. Doyle M, Roman D. Prevalence and survival of Campylobacter jejuni in unpasteurized milk. Appl Environ Microbiol. 1982;44(5):1154.

30. Davidson R, Sprung D, Park C, Raymond M. Occurrence of Listeria monocytogenes, Campylobacter spp., and Yersinia enterocolitica in Manitoba raw milk. Can Inst Food Sci Technol J. 1989;22:70-4.

31. van Kessel J, Karns J, Gorski L, McCluskey B, Perdue M. Prevalence of Salmonellae, Listeria monocytogenes, and Fecal Coliforms in Bulk Tank Milk on US Dairies*. J Dairy Sci. 2004;87(9):2822-30 .

32. Gran HM, Wetlesen A, Mutukumira AN, Rukure G, Narvhus JA. Occurrence of pathogenic bacteria in raw milk, cultured pasteurised milk and naturally soured milk produced at smallscale dairies in Zimbabwe. Food Control. 2003;14(8):539-44.

33. Seleem MN, Boyle SM, Sriranganathan N. Brucellosis: a reemerging zoonosis. Vet Microbiol. 2010;140(3-4):392-8. 
34. Christiansson A, Bertilsson J, Svensson B. Bacillus cereus spores in raw milk: factors affecting the contamination of milk during the grazing period. J Dairy Sci. 1999;82(2):305-14.

35. Giffel $M$, Wagendorp A, Herrewegh A, Driehuis F. Bacterial spores in silage and raw milk. Antonie Van Leeuwenhoek. 2002;81(1):625-30.

36. Arimi SM, Koroti E, Kang'ethe EK, Omore AO, McDermott JJ. Risk of infection with Brucella abortus and Escherichia coli O157:H7 associated with marketing of unpasteurized milk in Kenya. Acta Tropica. 2005;96(1):1-8.

37. Naing T. Prevalence survey of bovine brucellosis (Brucella abortus) in dairy cattle in Yangon, Myanmara. Thesis submitted to Chiang Mai University and freie Universität Berlin in partial fulfillment of the requirements for degree of master of veterinary public health. 2007.

38. Jayarao BM, Henning DR. Prevalence of Foodborne Pathogens in Bulk Tank Milk. J Dairy Sci. 2001;84(10):2157-62.

39. Benson W, Brock D, Mather J. Serologic analysis of a penitentiary group using raw milk from a q fever infected herd. Public Health Reports. 1963;78(2):707-10.

40. Kim W, Hahn T, Kim D, Lee M, Jung $\mathrm{K}$, Ogawa $\mathrm{M}$, Kishimoto $\mathrm{T}$, Lee $\mathrm{M}$, Lee S. Seroprevalence of Coxiella burnetii Infection in Dairy Cattle and Non-symptomatic People for Routine Health Screening in Korea. $J$ Korean Med Sci. 2006;21:823-6.

41. Loftis A, Priestley R, Massung R. Detection of Coxiella burnetii in Commercially Available Raw Milk from the United States. Foodborne Pathog Dis. 2010:973-4.

42. Agger F, Bodil Christoffersen A, Rattenborg E, Nielsen J, Agerholm S. Prevalence of Coxiella burnetii antibodies in danish dairy herds. Acta Vet Scand. 2010:52-5.
43. Öksüz Ö, Arici M, Kurultay $S$, Gümüs T. Incidence of Escherichia coli 0157 in raw milk and white pickled cheese manufactured from raw milk in Turkey. Food Control. 2004;15(6):453-6. 44. Reuben $A$, Treminio $H$, Arias $M$, Chaves C. Presencia de Escherichia coli 0157: H7, Listeria monocytogenes y Salmonella spp. en alimentos de origen animal en Costa Rica. Arch Latinoam Nutr. 2003;53(4).

45. Gilbert S, Lake R, Hudson A, Cressey P. Risk profile: Shiga-toxin producing Escherichia coli in raw milk. ERS. 2007.

46. Abdul-Raouf $U$, Ammar $M$, Beuchat L. Isolation of Escherichia coli O157: H7 from some Egyptian foods. Int J Food Microbiol. 1996;29(2-3):423-6.

47. Clarke R, McEwen S, Gannon V, Lior $\mathrm{H}$, Gyles C. Isolation of verocytotoxin-producing Escherichia coli from milk filters in south-western Ontario. Epidemiol Infect. 1989;102(2):253.

48. Steele ML, McNab WB, Poppe C, Griffiths MW, Chen S, Degrandis SA, Fruhner LC, Larkin CA, Lynch JA, Odumeru JA. Survey of Ontario bulk tank raw milk for food-borne pathogens. J Food Prot. 1997;60(11):1341-6.

49. de Louvois J, Rampling A. One fifth of samples of unpasteurised milk are contaminated with bacteria. BMJ. 1998;316(7131):625.

50. Chapman $P$, Wright $D$, Higgins R. Untreated milk as a source of verotoxigenic E. coli O:157. Vet Record (United Kingdom). 1993;33:171-2.

51. Klie $\mathrm{H}$, Timm $M$, Richter $\mathrm{H}$, Gallien $\mathrm{P}$, Perlberg $\mathrm{K}$, Steinrück $\mathrm{H}$. Detection and occurrence of verotoxinforming and/or shigatoxin producing Escherichia coli (VTEC and/or STEC) in milk. Berliner und Münchener tierärztliche Wochenschrift. 1997;110(9):337.

52. Fach $P$, Perelle S, Dilasser F, Grout J. Comparison between a PCR 
ELISA test and the vero cell assay for detecting Shiga toxin producing Escherichia coli in dairy products and characterization of virulence traits of the isolated strains. J Appl Microbiol. 2001;90(5):809-18.

53. Mckee R, Madden RH, Gilmour A. Occurrence of verocytotoxinproducing Escherichia coli in dairy and meat processing environments. J Food Prot. 2003;66(9):1576-80.

54. Wells J, Shipman L, Greene K, Sowers E, Green J, Cameron D, Downes F, Martin M, Griffin P, Ostroff S. Isolation of Escherichia coli serotype O157: H7 and other Shiga-like-toxinproducing E. coli from dairy cattle. J Clin Microbiol. 1991;29(5):985.

55. Kalorey DR, Warke SR, Kurkure NV, Rawool DB, Barbuddhe SB. Listeria species in bovine raw milk: A large survey of Central India. Food Control. 2008;19(2):109-12.

56. Desmasures $N$, Bazin $F$, Gueguen M. Microbiological composition of raw milk from selected farms in the Camembert region of Normandy. J Appl Microbiol. 1997;83(1):53-8.

57. Chye F, Abdullah A, Ayob M. Bacteriological quality and safety of raw milk in Malaysia. Food Micriobiol. 2004;21:535-41.

58. van Kessel J, Karns J, Wolfgang D. Enviromental sampling to predict fecal prevalence of Salmonella in an intensive monitored dairy herd. J Food Prot. 2008;71:1967-73.

59. Adesiyun A, Webb L, Rahaman $S$. Microbiological quality of raw cow's milk at collection centers in Trinidad. $J$ Food Prot. 1995;58(2):139-46.

60. Vergara C, Collazos M, Torres F, González C, Lasso N, Sambony N, Ortega C. Prevalencia de brucelosis en la leche cruda de bovinos expendida en el municipio de Popayán cauca septiembre - diciembre 2006. Facultad de Ciencias Agropecuaria. 2008;6(2):7685.
61. Moreno F, Martínez G, Mancera V, Ávila L, Vargas M. Análisis microbiológico y su relación con la calidad higiénica y sanitaria de la leche producida en la región del Alto de Chicamocha (departamento de Boyacá). Rev Med Vet. 2007;14:61-83.

62. Mosquera X, Bernal C, Muskus C, Berdugo J. Detección de Brucella abortus por PCR en sangre y leche de vacunos. Revista MVZ Córdoba. 2008;13(3):1504-13.

63. Rueda A. Utilización de la reacción en cadena de la polimerasa (PCR) en tiempo real para determinar la incidencia de Listeria monocytogenes en leches crudas en el departamento de Boyacá. Tesis de Maestría. 2005; Universidad de los Andes, Bogotá. 64. Vanegas $M$, Martinez A. Serotipificación molecular de cepas colombianas de Listeria monocytogenes. Alimentos Hoy. 2008;13:1-7.

65. Neira B, Silvestrini J. Análisis del proceso de ordeno y de la calidad higiénica de la leche utilizada en la fabricación del queso paipa en Paipa (Boyacá). Revista de Investigación U La Salle. 2006;6(2):163-270.

66. Carrascal A, Albarracín Y, Sarmiento P. Incidencia de Listeria monocytogenes en leche de vaca expendida en el municipio de Pamplona, Colombia. Bistua. 2007;5(2):49-57.

67. Torres C, Clavijo R, Cotrino V. Aislamiento de Mycobacterium bovis en leches de bovinos tuberculino positivos con presencia de mastitis crónica. Rev Med Vet Zoot. 1982;35(1-2):31-7.

68. Romero R, Garzon D, Mejía G, Monroy W, Patarroyo M, Murillo L. Identification of Mycobacterium bovis in bovine clinical samples by PCR speciesspecific primers. Can J Vet Res. 1999;63(2):101.

69. Martínez M, Gómez C, Serpa J. Diagnósticos de la calidad composicional e higiénico sanitaria de la 
leche cruda en centros de acopio y plantas procesadoras de del departamento de Sucre 2009. Universidad de Sucre. 2010.

70. Calderón A, Rodríguez V. Prevalencia de mastitis bovina y su etiología infecciosa en sistemas especializados en producción de leche en el altiplano cundiboyacense (Colombia). Rev Colomb Cienc Pecu. 2008;21:582-9.

71. Calderón R, Rodríguez R, Arrieta $B$, Mattar V. Prevalencia de mastitis bovina en sistemas doble propósito en Montería (Colombia): Etiología y susceptibilidad antibacteriana. Rev $\mathrm{Col}$ Cienc Pec. 2010.

72. MPS. Ministerio de la Protección Social de Colombia. Sistema de Inspección, Vigilancia y Control de las Direcciones Territoriales de Salud (IVC) . 2010.

73. Headrick M, Korangy S, Bean N, Angulo F, Altekruse S, Potter M, Klontz $\mathrm{K}$. The epidemiology of raw milk associated foodborne disease outbreaks reported in the United States ,19731992. Am J Pub Health. 1998;88(8):1219-21.

74. De Buyser M, Dufour B, Maire M, Lafarge V. Implication of milk and milk products in foodborne diseases in France and in different industrialised countries. Int $J$ Food Micriobiol. 2001;67:1-17.

75. Gillespie I, Adak G, O'Brien S, Bolton F. Milk borne outbreaks of infectious intestinal disease, England and wale's, 1992-200. Epidemiol Infect. 2003;130:461-8.

76. Newkirk R, Hedberg C, Bender J. Establishing a Milkborne Disease Outbreak Profile: Potential Food Defense Implications. Foodborne Pathog Dis. 2001;8(3):433-7.

77. CDPH. Epidemiologic Summary of Human Brucellosis in California, 2001 - 2008. Center for Infectious Diseases Division of Communicable Disease
Control Infectious Diseases Branch Surveillance and Statistics Section. Disponible en: http://www.cdph.ca.gov/data/statistics/D ocuments/brucellosis-episummary.pdf. 78. Lundén J, Tolvanen R, Korkeala $\mathrm{H}$. Human listeriosis outbreaks linked to dairy products in Europe. J Dairy Sci. 2004;87:E6-E12.

79. Lake R, Gilbert S, Lok Wong T, Cressey P. Risk profile: Mycobacterium bovis in milk. . A Crown Research Institute. 2009:1-38.

80. EFSA. (European Food Safety Authority), European Centre for Disease Prevention and Control; The European Union Summary Report on Trends and Sources of Zoonoses, Zoonotic Agents and Food-borne Outbreaks in 2009; EFSA Journal 2011; 9(3):2090.Disponible en: www.efsa.europa.eu/efsajournal.

81. Aghoghovbia S, Bañez C, Hunt $C$, Hansen G. Outbreak of Campylobacter jejuni Infections Associated with Consumption of Cheese Made from Raw Milk -Western Kansas, 2007. Kansas Department of Health \& Environment. 2007.

82. Harrington P, Archer J, Davis J, Croft D, Varma J. Outbreak of Campylobacter jejuni infections associated with drinking unpasteurized milk procured through a cow-leasing program-Wisconsin, 2001. MMWR 2002;51:548-9.

83. FDA. Public Health Agencies Warn of Outbreaks Related to Drinking Raw Milk.2010. Disponible en: http://www.fda.gov/NewsEvents/Newsro om/PressAnnouncements/ucm206311.h tm. Consulta Febrero 2011.

84. Lewis D. Nine sickened by Campylobacter / IIIness linked to raw milk. 2010. Disponible en: http://www.standard.net/topics/food/201 0/05/17/nine-sickened-campylobacterillness-linked-raw-milk. 
85. Department of Health Information for a Healthy New York. Campylobacter Contamination Found in Raw Milk 5 Reports of Illness May be Related to Consuming Raw Milk from Saratoga Farm. Disponible en: http://www.health.state.ny.us/press/relea ses/2010/2010-01-

29 campylobactor contamination in ra w milk.htm. Consulta Abril 2011.

86. Fleming J, Kriedeman $\mathrm{S}$. Pennsylvania agriculture department suspends raw milk sales permit of pasture maid creamery in Lawrence county. Department of health receives new reports of sickened consumers. Disponible en: http://www.prnewswire.com/newsreleases/pennsylvania-agriculturedepartment-suspends-raw-milk-salespermit-of-pasture-maid-creamery-inlawrence-county-90216057.html. Consulta Abril 2011.

87. Fleming J, Kriedeman $\mathrm{S}$. Consumer advisory: agriculture, health departments warn consumers about raw milk sold in Lawrence County. Disponible en: http://www.prnewswire.com/newsreleases/consumer-advisory-agriculturehealth-departments-warn-consumersabout-raw-milk-sold-in-lawrence-county89143257.html. Consulta Abril 2011.

88. Flynn D. Foodborne Illness Outbreaks:Campylobacter Outbreak Expands. 2009. Disponible en: http://www.foodsafetynews.com/2009/09 l-after-unpasteurized-milk-sickened/.

89. Washington state department of agriculture.Recent illnesses are reminder of risks from drinking raw milk.2009. Disponible en: http://agr.wa.gov/News/2009/09-

38.aspx. Consulta Abril 2011.

90. Pennsylvania Department of Health. Campylobacter spp. in raw milk. Disponible en: http://www.dsf.health.state.pa.us/health/
cwp/view.asp?A=190\&Q=251618.

Consulta Abril 2011.

91. Campylobacter Lawyer.The Alexandre eco farms dairy raw milk Campylobacter outbreak.2009.

Disponible en:

http://www.marlerblog.com/legalcases/the-alexandre-eco-farms-dairyraw-milk-campylobacter-outbreak/. Consulta Abril 2011.

92. CDC.Campylobacter in raw milk. Disponible en: http://onibasu.com/archives/cl/22958.ht ml. Consulta Abril 2011.

93. The Kansas Department of Health and EnvironmentKDHE and KDA remind consumers of health risks tied to raw milk. 2007. Disponible en: http://www.kdheks.gov/news/web archiv es/2007/12042007a.htm. Consulta Abril 2011.

94. Washington state Department of Agriculture. Campylobacter found in raw milk sold in whatcom, skagit, snohomish, king counties. 2007. Disponible en: http://www.highbeam.com/doc/1P31400755841.html. Consulta Abril 2011. 95. Heuvelink AE, Van Heerwaarden C, Zwartkruis-Nahuis A, Tilburg JJHC, Bos $\mathrm{MH}$, Heilmann FGC, Hofhuis $A$, Hoekstra T, De Boer E. Two outbreaks of campylobacteriosis associated with the consumption of raw cows' milk. Int $J$ Food Microbiol. 2009;134(1-2):70-4.

96. Connecticut Local News. E. Coli in Connecticut raw milk. Disponible en: http://www.nbc30.com/news/17041959/d etail.html. Consulta Abril 2011.

97. Allerberger F, Friedrich A, Grif K, Dierich $M$, Dornbusch $H$, Mache $C$, Nachbaur $E$, Freilinger $M$, Rieck $P$, Wagner M, Caprioli A, Karch $H$, Zimmerhackl L. Hemolytic-uremic syndrome associated with enterohemorragic Escherichia coli 026: $\mathrm{H}$ infection and consumption of unpasteurized cow's milk. Int $J$ Infect Dis. 2003;7:42-5. 
98. Minnesota Department of Health. E. coli illnesses traced to raw milk from Gibbon dairy farm.2010. Disponible en: http://www.health.state.mn.us/news/pres srel/2010/ecoli052610.html.

99. MacDonald K. E. coli update: new illnesses point out potential raw milk hazards.2010. Disponible en: http://www.doh.wa.gov/Publicat/2010 n ews/10-087.htm. Consulta Abril 2011. 100. CDC. Escherichia coli 0157:H7 Infections in Children Associated with Raw Milk and Raw Colostrum From Cows --- California, 2006. Disponible en: http://www.cdc.gov/mmwr/preview/mmw rhtml/mm5723a2.htm. Consulta Abril 2011.

101. CDC. Escherichia coli O157:H7 Infection Associated with Drinking Raw Milk -Washington and Oregon, November-December 2005. Disponible en:

http://www.cdc.gov/mmwr/preview/mmw rhtml/mm5608a3.htm. Consulta Abril 2011.

102. CDC. Outbreak of Listeriosis Associated with Homemade MexicanStyle Cheese - North Carolina, October 2000-January 2001. MMWR. 2001;50(26):560-2.

103. Brosch R, Gordon S, Marmiesse M, Brodin P, Buchrieser C, Eiglmeier K, Garnier T, Gutierrez C, Hewinson G, Kremer K. A new evolutionary scenario for the Mycobacterium tuberculosis complex. Proceedings of the National Academy of Sciences of the United States of America. 2002;99(6):3684.

104. CDC. Outbreak of MultidrugResistant Salmonella enterica serotype Newport Infections Associated with Consumption of Unpasteurized Mexican-Style Aged Cheese --- Illinois, March 2006--April 2007. Disponible en: http://www.cdc.gov/mmwr/preview/mmw rhtml/mm5716a4.htm. Consulta Abril 2011.

105. CDC. Multistate Outbreak of Salmonella Serotype Typhimurium
Infections Associated with Drinking Unpasteurized Milk --- Illinois, Indiana, Ohio, and Tennessee, 2002--2003. Disponible en: http://www.cdc.gov/mmwr/preview/mmw rhtml/mm5226a3.htm. Consulta Abril 2011

106. CDC. Salmonella Typhimurium Infection Associated with Raw Milk and Cheese Consumption --- Pennsylvania, 2007. Disponible en: http://www.cdc.gov/mmwr/preview/mmw rhtml/mm5644a3.htm. Consulta Abril 2011.

107. do Carmo L, Dias R, Linardi V, José de Sena M, Aparecida dos Santos $D$, Eduardo de Faria M, Pena E, Jett M, Heneine L. Food poisoning due to enterotoxigenic strains of Staphylococcus present in Minas cheese and raw milk in Brazil. Food Microbiol. 2002;19(1):9-14.

108. SIVIGILA. Sistema Nacional de Vigilancia en Salud Pública. Reportes Enfermedades Transmitidas por Alimentos ETA. Bogotá, 2007 - 2010.

109. López M, Álvarez C, Chávez J, Guerrero J. Grupo factores de riesgo ambiental, Instituto Nacional de Salud. Informe de vigilancia de las enfermedades transmitidas por alimentos, Semanas epidemiologicas 1 a 53, Colombia. 2009.

110. Paredes A. Final de brucelosis humana datos retrospectivos en Colombia 2009. Instituto Nacional de Salud. Subdirección de vigilancia y control en salud publica. Colombia. REG-R02.001.4000-001.

111. de Kantor I, LoBue P, Thoen C. Human tuberculosis caused by Mycobacterium bovis in the United States, Latin America and the Caribbean. Int $J$ Tuberc Lung Dis. 2010;14(11):1369-73.

112. Vilas-Bôas G, Peruca A, Arantes O. Biology and taxonomy of Bacillus cereus, Bacillus anthracis, and Bacillus 
thuringiensis. Can J Microbiol. 2007;53(6):673-87.

113. Martínez-Blanch J, Sánchez G, Garay E, Aznar R. Evaluation of phenotypic and PCR-based approaches for routine analysis of Bacillus cereus group foodborne isolates. Antonie Van Leeuwenhoek. 2011:1-13.

114. FDA. Bacteriological Analytical Manual. Chapter 14: Bacillus cereus. 2003. Disponible en: http://www.fda.gov/Food/ScienceResear ch/LaboratoryMethods/BacteriologicalAn alyticalManualBAM/UCM070875. Consulta Febrero 2011.

115. Scholz HC, Hubalek Z, Sedlacek I, Vergnaud G, Tomaso H, Al Dahouk S, Melzer F, Kampfer $P$, Neubauer $H$, Cloeckaert A. Brucella microti spp. nov., isolated from the common vole Microtus arvalis. Int $J$ Syst Evol Microbiol. 2008;58(2):375.

116. Foster G, Osterman BS, Godfroid J, Jacques I, Cloeckaert A. Brucella ceti spp. nov. and Brucella pinnipedialis spp. nov. for Brucella strains with cetaceans and seals as their preferred hosts. Int $J$ Syst Evol Microbiol. 2007;57(11):2688.

117. Yagupsky P. Detection of Brucellae in blood cultures. I Clin Microbiol. 1999;37(11):3437.

118. FAO/OIE/OMS. Brucellosis in humans and animals. Genova,Suiza. 2006.

119. ICA. Avance Erradicación Brucelosis. 2010. Disponible en: http://www.ica.gov.co/Areas/Pecuaria/S ervicios/Enfermedades-

Animales/Brucelosis-Bovina-(1)/AvanceErradicacion-de-Brucelosis.aspx. 120. Hansson I. Bacteriological and Epidemiological Studies of Campylobacter spp. in Swedish Broilers. Acta Universitatis Agriculturae Sueciae. 2007. Disponible en http://dissepsilon.slu.se:8080/archive/00001461/0 1/Avhandling $\mathrm{nr} 63.2007$ tryckfil Ingrid Hansson reserv.pdf.
121. Doyle M, Beuchat L, Montville T. Microbiología de los Alimentos. Fundamentos y Fronteras. Editorial Acribia Zaragoza, España. 2005.

122. Penner J. The genus Campylobacter: a decade of progress. Clin Microbiol Rev. 1988;1(2):157.

123. OIE. (Organización Mundial de Sanidad Animal) Manual de la OIE sobre animales terrestres Cap 12. 2004 P1222.

124. FDA. Bacteriological Analytical Manual 2007: Chapter 7 Campylobacter. Disponible en: http://www.fda.gov/Food/ScienceResear ch/LaboratoryMethods/BacteriologicalAn alyticalManualBAM/UCM072616.

Consulta Febrero 2011.

125. OIE. Organización Mundial de Sanidad Animal. Campylobacter jejuni y Campylobacter coli. Manual de la OIE sobre animales terrestres.2008. Disponible en http://www.oie.int/ESP/normes/mmanual /pdf es 2008/2.09.03.\%20Campilobact er\%20jejuni.pdf.

126. CFSPH. The Center for the foood security and public health. lowa Stete University . Q fever. 2007.

127. Heinzen R, Samuel J. The Genus Coxiella. The Prokaryotes. 2005;5:529-46.

128. Nataro J, Kaper J. Diarrheagenic Escherichia coli. Clin Microbiol Rev. 1998;11(1):142.

129. FDA. Bacteriological Analytical Manual 2009: Chapter 4a. Diarreic E. coli.Disponible en: http://www.fda.gov/Food/ScienceResear ch/LaboratoryMethods/BacteriologicalAn alyticalManualBAM/UCM070080. Consulta Febrero 2011.

130. Graves LM, Helsel LO, Steigerwalt AG, Morey RE, Daneshvar $\mathrm{MI}$, Roof SE, Orsi RH, Fortes ED, Milillo $\mathrm{SR}$, Den Bakker HC. Listeria marthii sp. nov., isolated from the natural environment, Finger Lakes National 
Forest. Int $J$ Syst Evol Microbiol. 2010;60(6):1280.

131. Leclercq A, Clermont D, Bizet C, Grimont PAD, Le Fleche-Mateos A, Roche SM, Buchrieser C, Cadet-Daniel V, Le Monnier A, Lecuit M. Listeria rocourtiae spp. nov. Int J Syst Evol Microbiol. 2010;60(9):2210.

132. Bell C, Kyriakides M. Listeria. Una aproximacion practica al microorganismo su control en los alimentos. Editorial Acribia, Primera edición. Pg 173. 2000.

133. Vazquez-Boland J, Kuhn M, Berche $P$, Chakraborty T, DominguezBernal G, Goebel W, Gonzalez-Zorn B, Wehland J, Kreft J. Listeria pathogenesis and molecular virulence determinants. Clin Microbiol Rev. 2001;14(3):584 .

134. FDA. Bacteriological Analytical Manual (BAM) : Chapter 10: Detection and Enumeration of Listeria monocytogenes in Foods. Disponible en:

http://www.fda.gov/Food/ScienceResear ch/LaboratoryMethods/BacteriologicalAn alyticalManualBAM/UCM071400.

135. Ministerio de Salud de Colombia. Manual de tecnicas de análisis para control de calidad microbiologico de alimentos para consumo humano. Instituto Nacional de Vigilancia de Medicamentos y Alimentos (INVIMA). División de Alimentos y Bebidas Alcoholicas. Sección de Microbiología de Alimentos. Colombia.1998.111-18 p.

136. Antognoli MC, Salman M, Triantis J, Hernandez J, Keefe T. A onetube nested polymerase chain reaction for the detection of Mycobacterium bovis in spiked milk samples: an evaluation of concentration and lytic techniques. $J$ Vet Diag Invest. 2001;13(2):111.

137. Lagatolla C, Dolzani L, Tonin E, Lavenia A, Di Michele M, Tommasini T, Monti-Bragadin C. PCR ribotyping for characterizing Salmonella isolates of different serotypes. J Clin Microbiol. 1996;34(10):2440.

138. Le Minor L, Popoff M. Designation of Salmonella enterica spp. nov., nom. rev., as the Type and Only Species of the Genus Salmonella: Request for an Opinion. Int J Sys Evol Microbiol. 1987;37(4):465.

139. Reeves M, Evins G, Heiba A, Plikaytis B, Farmer 3rd J. Clonal nature of Salmonella typhi and its genetic relatedness to other salmonellae as shown by multilocus enzyme electrophoresis, and proposal of Salmonella bongori comb. nov. J Clin Microbiol. 1989;27(2):313.

140. Tindall B, Grimont P, Garrity G, Euzeby J. Nomenclature and taxonomy of the genus Salmonella. Int J Sys Evol Microbiol. 2005;55(1):521.

141. Judicial Commission of the International Committee on Systematics of Prokaryotes. The type species of the genus Salmonella Lignieres 1900 is Salmonella enterica (ex Kauffmann and Edwards 1952) Le Minor and Popoff 1987, with the type strain LT2T, and conservation of the epithet enterica in Salmonella enterica over all earlier epithets that may be applied to this species. Opinion 80. Int J Syst Evol Microbiol. 2005;55(1):519-20.

142. Kim H, Park S, Kim H. Comparison of Salmonella enterica serovar Typhimurium LT2 and non-LT2 Salmonella genomic sequences, and genotyping of Salmonellae by using PCR. Appl Environ Microbiol. 2006;72(9):6142.

143. Olsen SJ, MacKinnon L, Goulding JS, Bean NH, Slutsker L. Surveillance for foodborne-disease outbreaks-United States, 1993-1997. MMWR 2000;49(1):1-62.

144. Eswarappa S, Janice J, Nagarajan A, Balasundaram S, Karnam G, Dixit N, Chakravortty D. Differentially evolved genes of Salmonella pathogenicity islands: insights into the 
mechanism of host specificity in Salmonella. PLOS one. 2008;3(12):3829.

145. FDA. Bacteriological Analytical Manual 2007: Chapter 5 Salmonella spp.Disponible en: http://www.fda.gov/Food/ScienceResear ch/LaboratoryMethods/BacteriologicalAn alyticalManualBAM/ucm070149.

Consulta Febrero 2011.

146. Le Loir Y, Baron F, Gautier M. Staphylococcus aureus and food poisoning. Genet Mol Res. 2003;2(1):63-76.

147. Adams M. Staphylococcus aureus and other pathogenic Grampositive cocci. 2th ed. editors. BCaMP, editor. Washington: CRC Press; 2009. 148. SCVPH. (Scientific Committee on Veterinary Measures Relating to Public Health). Staphylococcal enterotoxins in milk products, particularly cheeses. 2003.

149. FDA. Bacteriological Analytical Manual. Chapter 12: Staphylococcus aureus. Disponible en: http://www.fda.gov/Food/ScienceResear ch/LaboratoryMethods/BacteriologicalAn alyticalManualBAM/UCM071429.

Consulta Febrero 2011.

150. FDA. Bacteriological Analytical Manual. Chapter 13A: Staphylococcal Enterotoxins: Micro-slide Double Diffusion and ELISA-based Methods. Disponible en: http://www.fda.gov/Food/ScienceResear ch/LaboratoryMethods/BacteriologicalAn alyticalManualBAM/UCM073674. Consulta Febrero 2011.

151. Montville T, Matthews K. Microbiologia de los Alimentos: Introducción. Editorial Acribia, España. 447 p. 2009.

152. FDA. Bacteriological Analytical Manual. Chapter 8: Yersinia enterocolitica.

http://www.fda.gov/Food/ScienceResear $\underline{\mathrm{ch} / \text { LaboratoryMethods/BacteriologicalAn }}$
alyticalManualBAM/UCM072633.

Consulta Febrero 2011.

153. Sears CL, Kaper JB. Enteric bacterial toxins: mechanisms of action and linkage to intestinal secretion. Microbiol Mol Biol Rev. 1996;60(1):167. 154. Carlin F, Brillard J, Broussolle V, Clavel T, Duport C, Jobin M. Adaptation of Bacillus cereus, an ubiquitous worldwide-distributed foodborne pathogen, to a chaling enviroment. Food Res Int. 2010;43:1885-18894.

155. Lake R, Hudson A, Cressey P. Risk Profile: Bacillus spp. In rice. Institute of environmental science and research limited. 39 p. 2004.

156. Kotiranta A, Lounatmaa K, Haapasalo M. Epidemiology and pathogenesis of Bacillus cereus infections. Microbes Infect. [doi: 10.1016/S1286-4579(00)00269-0]. 2000;2(2):189-98.

157. Park Y, Kim J, Shin S, Kim J, Cho S, Lee B, Ahn J, Kim J, Oh D. Prevalence, genetic diversity, and antibiotic susceptibility of Bacillus cereus strains isolated from rice and cereals collected in Korea. $J$ Food Prot. 2009;72(3):612-7.

158. FAO/OMS. 1986. Comité Mixto FAO/OMS de Expertos en Brucelosis. Sexto Informe. Serie de informes técnicos de la OMS № 740. Disponible en

http://www.fao.org/docrep/u2200s/u2200 s0o.htm.

159. Seow C, Barkham T, Wong $P$, Lin L, Pada S, Tan S. Brucellosis in a Singaporean with prolonged fever. Singapore Med J. 2009;9(312-314).

160. Franco M, Mulder M, Gilman R, Smits P. Human brucelosis. Lancet Infect Dis. 2007;7(775-86).

161. 1st International Conference on Emerging Zoonoses Jerusalem, Israel. 1997. Brucellosis: an Overview. Emerg Infect Dis. 3(2):213-221. 
162. Castro H, Gonzalez S, Prat M. Brucelosis: una revisión práctica. Acta Bioquim Clin Latinoam. 2005.

163. Corbel MJ. Brucellosis in humans and animals: WHO (Word Health Organization) press. 89 p 2006.

164. ICMSF. International Commission on Microbiological Specifications for Foods, Microorganismos de los Alimentos: Características de los Patógenos Microbianos. Ed Acribia España. 1998. 165. Vliet A, Ketley J. Pathogenesis of enteric Campylobacter infection. J Appl Microbiol. 2001;90:45-56.

166. Potter R, Kaneene J, Hall W. Risk factors for sporadic Campylobacter jejuni infections in rural Michigan: a prospective case-control study. $A m \mathrm{~J}$ Public Health. 2003;93(12):2118.

167. Hariharan H, Murphy G, Kempf I. Campylobacter jejuni: Public health hazards and potential control methods in poultry: a review. Vet Med Czech. 2004;11:441-6.

168. Wassenaar T. Toxin production by Campylobacter spp. Clin Microbiol Rev. 1997;10(3):466.

169. Walker $R$, Caldwell $M$, Lee $E$, Guerry P, Trust T, Ruiz-Palacios G. Pathophysiology of Campylobacter Enteritis. . Microbiol Rew. 1986;1:81-94. 170. Mead P, Slutsker L, Dietz V, McCaig L, Bresee J, Shapiro C, Griffin $P$, Tauxe R. Food-related illness and death in the United States. Emerg Infect Dis. 1999;5(5):607.

171. CDC. Q Fever. Georgia. 2009. Disponible en: http://www.cdc.gov/ncidod/dvrd/qfever/. Consulta Abril 2011.

172. Mo YY, Cianciotto NP, Mallavia LP. Molecular cloning of a Coxiella burnetii gene encoding a macrophage infectivity potentiator (Mip) analogue. Microbiol. 1995;141(11):2861.

173. Moodie CE, Thompson HA, Meltzer MI, Swerdlow DL. Prophylaxis after exposure to Coxiella burnetii. Emerg Infect Dis. 2008;14(10):1558.

174. Rodríguez-Angeles Principales características y diagnóstico de los grupos patógenos de Escherichia coli. Salud Pública de México. 2002;44(5):464-75.

175. Bacon R, Sofos J. Characteristics of biological Hazards in foods. In: Schmidt $R H$, Rodrick GE, editors Food safety Handbook John Wiley \& Sons, Inc, Hoboken, New Jersey. 2003:156-67.

176. FDA/USDA/CDC. Quantitative assessment of relative risk to public health from foodborne Listeria monocytogenes among selected categories of ready to eat foods 2003 . Disponible en: http://www.fda.gov/downloads/Food/Sci enceResearch/ResearchAreas/RiskAss essmentSafetyAssessment/UCM197330 .pdf. Consulta Abril 2011.

177. Allerberger $\mathrm{F}$, Wagner $\mathrm{M}$. Listeriosis: a resurgent foodborne infection. Clin Microbiol Infect. 2010;16:16-23.

178. Dalton C, Austin C, Sobel J, Hayes P, Bibb W, Graves L, Swaminathan B, Proctor M, Griffin P. An outbreak of gastroenteritis and fever due to Listeria monocytogenes in milk. $N$ Engl J Med. 1997;2:100-5.

179. FAO-OMS. Evaluación de riesgos de Listeria monocytogenes en alimentos listos para el Consumo. 2004. Disponible en URL ftp://ftp.fao.org/es/esn/jemra/mra4 es.pd $\underline{f}$

180. Torres K, Sierra S, Poutou R, Vera $H$, Carrascal A, Mercado $M$. Incidencia y diagnóstico de Listeria monocytogenes; microorganismo zoonótico emergente en la industria de alimentos. . UDCA Actualidad \& Divulgación Científica. 2004;7(1):25-57. 181. Portnoy D, Chakraborty T, Goebel W, Cossart P. Molecular 
determinants of Listeria monocytogenes pathogenesis. Infect Immun. 1992;60(4):1263.

182. Berche P, Gaillard J, Richard S. Invasiveness and Intracellular Growth of Listeria monocytogenes. Infection. 1988;(Suppl. 2):145-8.

183. Schuchat A, Deaver K, Wenger J, Plikaytis B, Mascola L, Pinner R, Reingold A, Broome C. Role of foods in sporadic listeriosis: I. Case-control study of dietary risk factors. Jama. 1992;267(15):2041.

184. Drevets D, Bronze M. Listeria monocytogenes: epidemiology, human disease, and mechanisms of brain invasion. FEMS Immunol Med Microbiol. 2008;53:151-65.

185. McLauchlin J. Human listeriosis in Britain, 1967-85, a summary of 722 cases: 2. Listeriosis in non-pregnant individuals, a changing pattern of infection and seasonal incidence. Epidemiol Infect. 1990;104(02):191-201. 186. Farber J, Peterkin P. Listeria monocytogenes, a food-borne pathogen. Microbiol Mol Biol Rev. 1991;55(3):476. 187. EFSA. The Community Summary Report on Trends and Sources of Zoonoses, Zoonotic Agents, Antimicrobial Resistance and Foodborne Outbreaks in the European Union in 2005. The EFSA Journal. 2006;94:1288.

188. FSAl. (Food Safety Authority of Ireland), The Control and Management of Listeria monocytogenes Contamination of Food. Abbey Court Lower Abbey Street Dublin 2005 pp 94. 2005.

189. FDA. Foodborne Pathogenic Microorganisms and natural toxins Handbook. Listeria monocytogenes. Disponible en http://www.fda.gov/food/foodsafety/food borneillness/foodborneillnessfoodbornep athogensnaturaltoxins/badbugbook/ucm 070064.htm. Consulta Febrero 2011.
190. Majoor CJ, Magis-Escurra C, van Ingen J, Boeree MJ, van Soolingen D. Epidemiology of Mycobacterium bovis Disease in Humans, the Netherlands, 1993-2007. Age. 2011;19:20-4.

191. O'Reilly LM, Daborn C. The epidemiology of Mycobacterium bovis infections in animals and man: a review. Tubercle Lung Dis. 1995;76:1-46.

192. Wilkins MJ, Meyerson J, Bartlett PC, Spieldenner SL, Berry DE, Mosher LB, Kaneene JB, Robinson-Dunn B, Stobierski MG, Boulton ML. Human Mycobacterium bovis infection and bovine tuberculosis outbreak, Michigan, 1994-2007. Emerg Infect Dis. 2008;14(4):657.

193. Borrero R, Álvarez N, Reyes F, Sarmiento ME, Acosta A. Mycobacterium tuberculosis: factores de virulencia. VacciMonitor. 2011;20(1):348.

194. Moda G, Daborn C, Grange J, Cosivi O. The zoonotic importance of Mycobacterium bovis. Tubercle Lung Dis. 1996;77(2):103-8.

195. Bhatia A, Zahoor S. Staphylococcus aureus enterotoxins: a review. J Clin Diag Res. 2007;2:188-97.

196. Adwan G, Abu-Shanab B, Adwan K. Enterotoxigenic Staphylococcus aureus in raw milk in the North of Palestine. Turk J Biol. 2005;29:229-32.

197. Pinchuk I, Beswick E, Reyes V. Staphylococcal Enterotoxins. Toxins. $2010 . \quad$ Disponible en: www.mdpi.com/journal/toxins. Consulta Abril 2011.

198. do Carmo LS, Cummings C, Roberto Linardi V, Souza Dias R, Maria De Souza J, De Sena MJ, Aparecida Dos Santos D, Shupp JW, Karla Peres Pereira R, Jett M. A case study of a massive staphylococcal food poisoning incident. Foodborne Pathog Dis. 2004;1(4):241-6.

199. Blaiotta G, Ercolini D, Pennacchia C, Fusco V, Casaburi A, Pepe O, Villani F. PCR detection of 
staphylococcal enterotoxin genes in Staphylococcus spp. strains isolated from meat and dairy products. Evidence for new variants of seG and sel in $S$. aureus AB-8802. J Appl Microbiol. 2004;97:719-30.

200. Loncarevic S, Jørgensen $H$, Løvseth A, Mathisen T, Rørvik L. Diversity of Staphylococcus aureus enterotoxin types within single samples of raw milk and raw milk products. $J$ Appl Microbiol. 2005;98(2):344-50.

201. Ertas N, Gonulalan Z, Yildirim Y, Kum E. Detection of Staphylococcus aureus enterotoxins in sheep cheese and dairy desserts by multiplex PCR technique. Int $J$ Food Microbiol. 2010;142:74-7.

202. Ikeda T, Tamate N, Yamaguchi K, Makino S. Mass Outbreak of Food Poisoning Disease Caused by Small Amounts of Staphylococcal Enterotoxins $A$ and H. Appl Environ Microbiol. 2005;71:2793-5.

203. Boynukara B, Gulhan T, Alisarli M, Gurturk K, Solmaz H. Classical enterotoxigenic characteristics of Staphylococcus aureus strains isolated from bovine subclinical mastitis in Van, Turkey. Int $J$ Food Microbiol. 2008;125(2):209-11.

204. Erickson M. Recognition and Prevention of Staphylococcal Enterotoxins as Intentional Contaminants of Foods. 2000. Disponible en: http://www.ugacfs.org/faculty/Erickson/S taphylococcus.pdf.

205. Bautista L, Gaya P, Medina M, Nunez M. A quantitative study of enterotoxin production by sheep milk staphylococci. Appl Environ Microbiol. 1998;54:566-9.

206. Vernozy-Rozand C, Mazuy C, Prevost G, Lapeyre C, Bes M, Brun Y, Fleurette J. Enterotoxin production by coagulase-negative staphylococci isolated from goats' milk and cheese. Int J Food Microbiol. 1996;30(3):271-80.
207. Pelisser M, Klein C, Ascoli K, Zotti T, Arisi A. Ocurrence of Staphylococcus aureus and multiplex pcr detection of classic enterotoxin genes in cheese and meat products. Bras J Microbiol. 2009;40:145-8.

208. Morandi S, Brasca M, Lodi R, Cremonesi P, Castiglioni B. Detection of classical enterotoxins and identification of enterotoxin genes in Staphylococcus aureus from milk and dairy products. Vet Microbiol. 2007;124:66-72.

209. Haeghebaert S, Le Querrec F, Bouvet $\mathrm{P}$, Gallay A, Espié E, Vaillant V. Les toxi-infections alimentaires en France en 2001. Bulletin d'épidémiologie hebdomadaire. 2002;50(249-253).

210. Asao T, Kumeda Y, Kawai T, Shibata T, Oda H, Haruki K, Nakazawa $\mathrm{H}$, Ozaki S. An extensive outbreak of staphylococcal food poisoning due to low-fat milk in Japan: estimation of enterotoxin $A$ in the incriminated milk and powdered skim milk. . Epidemiol Infect. 2003;130(33-40).

211. Akineden $O$, Hassan $A$, Schneider E, Usleber E. Enterotoxigenic properties of Staphylococcus aureus isolated from goats' milk cheese. Int $J$ Food Microbiol. 2008;124:211-6.

212. Guven K, Mutlu M, Gulbandilar A, Cakir P. Occurrence and characterization of Staphylococcus aureus isolated from meat and dairy products consumed in Turkey. J Food Saf. 2010;30(196-212).

213. NZFSA. New Zealand Food Safety Authority. 2001. Microbial Pathogen Data Sheets: Yersinia enterocolitica. Disponible en: http://foodsafety.govt.nz/elibrary/industry YYersinia Enterocolitica-

Science Research.pdf.

214. Bottone E. Yersinia enterocolitica: the charisma continues. Clin Microbiol Rev. 1997;10(2):257.

215. Francis D, Spaulding P, Lovett J. Enterotoxin production and thermal 
resistance of Yersinia enterocolitica in milk. Appl Environ Microbiol. 1980;40(1):174.

216. FDA. Foodborne Pathogenic Microorganisms and Natural Toxins Handbook.Yersinia enterocolitica. Disponible en: http://www.bf.lu.lv/grozs/Mikrobiologijas/ Mediciniska mikrobiol/FDACFSAN\%20Bad\%20Bug\%20Book\%20\%20Yersinia\%20enterocolitica.htm. Consulta Febrero 2011.

217. Millogo V, Svennersten Sjaunja $\mathrm{K}$, Ouédraogo GA, Agenäs S. Raw milk hygiene at farms, processing units and local markets in Burkina Faso. Food Control. 2010;21(7):1070-4.

218. NZFSA. New Zealand Food Safety Authority. 2010. Microbial Pathogen Data Sheets: Bacillus cereus. Disponible en: http://www.foodsafety.govt.nz/elibrary/in dustry/Bacillus CereusSpore Forming.pdf.

219. NZFSA. New Zealand Food Safety Authority . 2001. Microbial Pathogen Data Sheets: Campylobacter spp. Disponible en: http://foodsafety.govt.nz/elibrary/industry Campylobacter-Organism Causes.pdf. 220. NZFSA. New Zealand Food Safety Authority. 2001. Microbial Pathogen Data Sheets: E. coli O157:H7. Disponible en http://www.nzfsa.govt.nz/science/datasheets/escherichia-coli-0157.pdf. 221. NZFSA. New Zealand Food Safety Authority. 2001. Microbial Pathogen Data Sheets: Listeria monocytogenes. Disponible en http://www.nzfsa.govt.nz/science/datasheets/listeria-monocytogenes.pdf. 222. Lado B, Yousef A. Characteristics of Listeria monocytogenes important to food processors. In: Ryser ET, Marth EH, editors. Listeria, listeriosis, and food safety. 3rd ed. Boca Raton: CRC Press; p. 157-214.2007.
223. NZFSA. New Zealand Food Safety Authority. Risk profile:Mycobacterium bovis in milk. 2009 Disponible en: http://www.foodsafety.govt.nz/elibrary/in dustry/Risk Profile MycobacteriumScience Research.pdf.

224. NZFSA. New Zealand Food Safety Authority . 2001. Microbial Pathogen Data Sheets:Mycobacterium bovis. Disponible en: http://foodsafety.govt.nz/elibrary/industry Mycobacterium BovisScience Research.pdf. 225. NZFSA. New Zealand Food Safety Authority. 2001. Microbial Pathogen Data Sheets: Salmonella spp. Disponible en http://www.nzfsa.govt.nz/science/datasheets/non-typhoid-salmonellae.pdf. . 226. NZFSA. New Zealand Food Safety Authority. Risk profile:Salmonella (non typhoid) in poultry (whole and pieces). 2002. Disponible en: http://www.foodsafety.govt.nz/elibrary/in dustry/Risk Profile SalmonellaScience Research.pdf. 227. NZFSA. New Zealand Food Safety Authority. 2001. Microbial Pathogen Data Sheets:Staphylococcus aureus. Disponible en http://www.nzfsa.govt.nz/science/datasheets/staphylococcus-aureus.pdf. 228. NZFSA. New Zealand Food Safety Authority. 2010. Microbial Pathogen Data Sheets: Yersinia enterocolitica. Disponible en: http://www.foodsafety.govt.nz/elibrary/in dustry/Yersinia EnterocoliticaScience Research.pdf.

229. Bandara A, Mahipala M. Incidence of brucellosis in Sri Lanka: an overview. Vet Microbiol. 2002;90(14):197-207.

230. FSANZ. (Food Standards Australia New Zealand). Microbiological Risk Assessment of Cow raw Milk. Disponible en: http://www.foodstandards.gov.au/ srcfile 
S/P1007\%20PPPS\%20for\%20raw\%20m ilk\%201AR\%20SD1\%20Cow\%20milk\% 20Risk\%20Assessment.pdf. Consulta Febrero 2011. 2009.

231. Coleman SA, Fischer ER, Howe D, Mead DJ, Heinzen RA. Temporal analysis of Coxiella burnetii morphological differentiation. J Bacteriol. 2004;186(21):7344.

232. Soomro A, Arain M, Khaskheli M, Bhutto B. Isolation of Escherichia coli from raw milk and milk products is relation to public health sold under market condition at Tandojam. Pak J Nutr. 2002;1(3):151-2.

233. Nightingale $\mathrm{K}$, Schukken $\mathrm{Y}$, Nightingale C, Fortes E, Ho A, Her Z, Grohn Y, McDonough P, Wiedmann M. Ecology and transmission of Listeria monocytogenes infecting ruminants and in the farm environment. Appl Environ Microbiol. 2004;70(8):4458.

234. Aygun O, Pehlivanlar S. Listeria spp. in the raw milk and dairy products in Antakya, Turkey. Food Control. 2006;17(8):676-9.

235. Moshtaghi H, Mohamadpour AA. Incidence of Listeria spp. in raw milk in Shahrekord, Iran. Foodborne Pathog Dis. 2007;4(1):107-10.

236. Pearson LJ, Marth EH. Listeria monocytogenes - Threat to a Safe Food Supply: A Review. J Dairy Sci. 1990;73(4):912-28.

237. Bradshaw J, Shah D, Forney E, Madden J. Growth of Salmonella enteritidis in yolk of shell eggs from normal and seropositive hens. J Food Protect. 1990;53(12):1033.

238. Heidinger J, Winter C, Cullor J. Quantitative Microbial Risk Assessment for Staphylococcus aureus and Staphylococcus Enterotoxin A in Raw Milk. J Food Prot. 2009;72(8):1641-53.

239. ICMSF. Microrganisms in Foods 5. Characteristics of Microbial Pathogens. Blackie Academic and Professional, London. 1996.
240. Holmann F, Rivas L, Carulla J, Giraldo LA, Guzman S, Martinez M, Rivera B, Medina A, Farrow A. Evolución de los Sistemas de Producción de Leche en el Trópico Latinoamericano y su interrelación con los Mercados: Un Análisis del Caso Colombiano. CIAT Consorcio Tropileche Cali, 53p. 2003.

241. Instituto Interamericano para la Cooperación Agrícola (IICA). Acuerdo de Competitividad de la cadena láctea colombiana. Colección documentos IICA. Serie de Competitividad No 12. Bogotá, D.C. 2005.

242. Klei L, Yun J, Sapru A, Lynch J, Barbano D, Sears P, Galton D. Effects of Milk Somatic Cell Count on Cottage Cheese Yield and Quality. J Dairy Sci. 1998;81(5):1205-13.

243. Lafarge V, Ogier JC, Girard V, Maladen V, Leveau JY, Gruss A, Delacroix-Buchet A. Raw cow milk bacterial population shifts attributable to refrigeration. Appl Environ Microbiol. 2004;70(9):5644.

244. Murinda S, Nguyen L, Nam H, Almeida R, Headrick S, Oliver S. Detection of sorbitol-negative and sorbitol-positive Shiga toxin-producing Escherichia coli, Listeria monocytogenes, Campylobacter jejuni, and Salmonella spp. in dairy farm environmental samples. Foodborne Pathog Dis. 2004;1(2):97-104.

245. FEDEGAN. Extracción mecánica y conservación de leche. Manual práctico del ganadero. 1999.

246. Barkema H, Green M, Bradley A, Zadoks R. The role of contagious disease in udeer health. J Dairy Sci. 2009;92(10):4717-29.

247. Ruegg P. Investigation of mastitis problems on farm Vet Clin Food Animal. 2004;19:47-73.

248. Nightingale KK, Fortes ED, Ho AJ, Schukken YH, Grohn YT, Wiedmann M. Evaluation of farm management practices as risk factors for clinical 
listeriosis and fecal shedding of Listeria monocytogenes in ruminants. J Am Vet Med Assoc. 2005;227(11):1808-14.

249. Tasci F, Turutoglu H, Ogutcu H. Investigations of Listeria species in milk and silage produced in Burdur province Kafkas. Univ Vet Fak Derg. 2010;16(Suppl-A):S93-S7.

250. Sanaa M, Poutrel B, Menard J, Serieys F. Risk factors associated with contamination of raw milk by Listeria monocytogenes in dairy farms. J Dairy Sci. 1993;76(10):2891-8.

251. Signorini M, Sequeira G, Bonazza J, Dalla Santina R, Mart L, Frizzo L, Rosmini M. Utilizacion de microorganismos marcadores para la evaluación de las condiciones higiénicosanitarias en la producción primaria de leche. Revista Cientifica Universidad de Zulia. 2008;8(2):207-17.

252. Pradhan A, Van Kessel J, Karns J, Wolfgang D, Hovingh E, Nelen K, Smith J, Whitlock R, Fyock T, Ladely S. Dynamics of endemic infectious diseases of animal and human importance on three dairy herds in the northeastern United States. J Dairy Sci. 2009;92(4):1811-25.

253. LeJeune J, Besser T, Merrill N, Rice D, Hancock D. Livestock drinking water microbiology and the factors influencing the quality of drinking water offered to cattle. $J$ Dairy Sci. $2001 ; 84(8): 1856-62$.

254. Kudva IT, Blanch K, Hovde CJ. Analysis of Escherichia coli O157: H7 survival in ovine or bovine manure and manure slurry. Appl Environ Microbiol. 1998;64(9):3166.

255. Oliver S, Jayarao B, Almeida R. Foodborne pathogens, mastitis, milk quality, and dairy food safety. NMC Annual Meeting Proceedings. 2005:327.

256. Blaser MJ, Glass RI, Huq MI, Stoll B, Kibriya G, Alim A. Isolation of Campylobacter fetus subsp. jejuni from
Bangladeshi children. J Clin Microbiol. 1980;12(6):744.

257. Hänninen $M L$, Niskanen $M$, Korhonen L. Water as a Reservoir for Campylobacter jejuni Infection in Cows Studied by Serotyping and Pulsed field Gel Electrophoresis (PFGE). J Vet Med B. 1998;45(1 10):37-42.

258. LeJeune JT, Besser TE, Hancock DD. Cattle water troughs as reservoirs of Escherichia coli 0157. Appl Environ Microbiol. 2001;67(7):3053.

259. Fitzgerald A, Edrington T, Looper M, Callaway T, Genovese K, Bischoff K, McReynolds J, Thomas J, Anderson R, Nisbet D. Antimicrobial susceptibility and factors affecting the shedding of $E$. coli O157: H7 and Salmonella in dairy cattle. Lett Appl Microbiol. 2003;37(5):392-8.

260. Philpot N, Nickerson S. Ganando la lucha contra las mastitis. 2000; Naperville (USA):192p.

261. Novoa R, Armenteros $M$, Abeledo M, Casanovas E, Valera $R$, Caballero C, Pulido J. Factores de riesgo asociados a la prevalencia de mastitis clínica y subclínica. Salud Anim 2005:27.

262. Rosengren $\AA$, Fabricius A, Guss $B$, Sylvén $S$, Lindqvist R. Occurrence of foodborne pathogens and characterization of Staphylococcus aureus in cheese produced on farmdairies. Int $J$ Food Microbiol. 2010;144:263-9.

263. Jorgensen $H$, Mork T, Caugant D, Kearns A, Rorvik L. Genetic Variation among Staphylococcus aureus Strains from Norwegian Bulk Milk. Appl Environ Microbiol. 2005;12:8352-61.

264. Calderón A, Donado P, Botero J, Jiménez G, García G. Mastitis bovina: Cuantificación de factores de riesgo asociados al funcionamiento del equipo de ordeño. Rev Med Vet Zoot Univ Nac Col. 2002;49(2):38-42.

265. Lues J, De Beer $H$, Jacoby $A$, Jansen K, Shale K. Microbial quality of milk, produced by small scale farmers in 
a peri-urban area in South Africa. African $J$ Microbiol Res. 2010;4(17):1823-30.

266. Schreiner D, Ruegg P. Relationship between udder and leg hygiene scores and subclinical mastitis. J Dairy Sci. 2003;86(11):3460-5.

267. Hassan L, Mohammed $\mathrm{H}$, McDonough P. Farm-management and milking practices associated with the presence of Listeria monocytogenes in New York state dairy herds. Prev Vet Med. 2001;51(1-2):63-73.

268. George G. Listeriosis: an emerging concern Surveillance 1987;14:7-8.

269. Abdala A. Tuberculosis Bovina. Rev Sancor. 1998;56(604):26-30.

270. Miller M, Paige J. Other food borne infections. Vet Clin North Am Food Anim Pract. 1998;14(1):71.

271. Muramatsu $\mathrm{Y}$, Yanase T, Okabayashi T, Ueno H, Morita C. Detection of Coxiella burnetii in cow's milk by PCR-enzyme-linked immunosorbent assay combined with a novel sample preparation method. Appl Environ Microbiol. 1997;63(6):2142.

272. Blowey, . E. El control de la mastitis bovina en granjas de ganado de leche. Guía práctica e ilustrada. Editorial Acribia, Zaragoza (España). 208p.1999. 273. Calderón A, Martínez N, Cardona J. Determinación de factores de protección para mastitis bovina en fincas administradas bajo el sistema doble propósito en el municipio de Montería. . Revista UDCA Actualidad \& Divulgación Científica. 2009;12(2):61-8.

274. Latorre AA, Van Kessel JAS, Karns JS, Zurakowski MJ, Pradhan AK, Zadoks RN, Boor KJ, Schukken YH. Molecular ecology of Listeria monocytogenes: evidence for a reservoir in milking equipment on a dairy farm. Appl Environ Microbiol. 2009;75(5):1315.

275. Latorre A, Van Kessel J, Karns J, Zurakowski M, Pradhan A, Boor K,
Jayarao B, Houser B, Daugherty C, Schukken Y. Biofilm in milking equipment on a dairy farm as a potential source of bulk tank milk contamination with Listeria monocytogenes. J Dairy Sci. 2010;93(6):2792-802.

276. Kirk J, Lauerman L, Roberts C. Mycoplasma mastitis in dairy cows. Compendium on Continuing Education for the Practicing Veterinarian. 1994;16(4):541-52.

277. Guerreiro P, Machado M, Braga G, Gasparino E, Franzener A. Microbiological quality of milk through preventive techniques in the handling of production. Ciência e Agrotecnologia. 2005;29(1):216-22.

278. Fox E, Hunt K, O'Brien M, Jordan $\mathrm{K}$. Listeria monocytogenes in Irish Farmhouse cheese processing environments. Int J Food Microbiol. 2010;145 (1):S39-S45.

279. Duffy G, Lynch O, Cagney C. Tracking emerging zoonotic pathogens from farm to fork. Meat Sci. 2008;78(12):34-42.

280. Magariños H. Producción higiénica de la leche cruda. Editorial Producción y Servicios Incorporados, Mateo Flores, Guatemala. 2000;95pp.

281. Michigan Deparment of Agriculture. Bulk Milk Haulers Training Manual. Food and Dairy Division. 2001. 282. Cempírková R. Psychrotrophic vs. total bacterial counts in bulk milk samples. Vet Medicine-Praha2002;47(8):227-33.

283. Arcuri E, Silva P, Brito M, Brito J, Lange C, Magalhães M. Contagem, isolamento e caracterização de bactérias psicrotróficas contaminantes de leite cru refrigerado. Ciencia rural. 2008;38:2250-5.

284. Lorenzetti D. Influência do tempo e da temperatura no desenvolvimento de microrganismos psicrotróficos no leite cru de dois estados da região sul [Dissertação Mestrado].Curitiba: Universidade Federal do Paraná. 2006. 
285. Warnick L, Kaneene J, Ruegg P, Wells S, Fossler C, Halbert L, Campbell A. Evaluation of herd sampling for Salmonella isolation on midwest and northeast US dairy farms. Prev Vet Med. 2003;60(3):195-206.

286. Antognoli M, Lombard J, Wagner B, McCluskey B, Van Kessel J, Karns J. Risk Factors Associated with the Presence of Viable Listeria monocytogenes in Bulk Tank Milk from US Dairies. Zoonoses Public Health. 2009;56(2):77-83.

287. Waterman S, Park R, Bramley A. A search for the source of Campylobacter jejuni in milk. J Hyg. 1984;93(02):333-7.

288. Barkema $H$, Schukken $Y$, Lam $T$, Beiboer M, Wilmink $H$, Benedictus $G$, Brand $A$. Incidence of clinical mastitis in dairy herds grouped in three categories by bulk milk somatic cell counts. J Dairy Sci. 1998;81(2):411-9.

289. Jayarao BM, Donaldson SC, Straley BA, Sawant AA, Hegde NV, Brown JL. A Survey of Foodborne Pathogens in Bulk Tank Milk and Raw Milk Consumption Among Farm Families in Pennsylvania. $J$ Dairy Sci. 2006;89(7):2451-8.

290. FSA. Food Standard Agency. Milk hygiene on the dairy farm, a practical guide for milk producers. 2004. 291. Waak E, Tham W, DanielssonTham ML. Prevalence and fingerprinting of Listeria monocytogenes strains isolated from raw whole milk in farm bulk tanks and in dairy plant receiving tanks. Appl Environ Microbiol. 2002;68(7):3366.

292. Kousta M, Mataragas M, Skandamis $\mathrm{P}$, Drosinos EH. Prevalence and sources of cheese contamination with pathogens at farm and processing levels. Food Control. 2010;21(6):805-15. 293. Albarracín F. Factores limitantes en el desarrollo de la cadena láctea de producción de leche y quesos frescos en el municipio de pamplona, Norte de Santander. 2007.

294. Convenio SDDE/ Fundación Alpina. Estudio de alternativas económicas, tecnológicas, logísticas, organizacionales y sociales para productores, comercializadores y consumidores de leche cruda en el Distrito Capital. 2010.

295. Tondo E, Guimarães M, Henriques J, Ayub M. Assessing and analysing contamination of a dairy products processing plant by Staphylococcus aureus using antibiotic resistance and PFGE. Can J Microbiol. 2000;46(12):1108-14.

296. Ruegg P. Relationship between bulk tank milk somatic cell count and antibiotic residues. Proc 44th National Mastitis Council Mtg, Orlando, FL Natl Mastitis Counc, Inc, Verona, WI. 2005:28-35.

297. Roberson J, Fox L, Hancock D, Gay J, Besser T. Ecology of Staphylococcus aureus Isolated from Various Sites on Dairy Farms. J Dairy Sci. 1994;77(11):3354-64.

298. Vautor E, Abadie G, Guibert JM, Huard C, Pepin M. Genotyping of Staphylococcus aureus isolated from various sites on farms with dairy sheep using pulsed-field gel electrophoresis. Vet Microbiol. 2003;96(1):69-79.

299. McNaughton $R$, Leyland $R$, Mueller L. Outbreak of Campylobacter enteritis due to consumption of raw milk. Canadian Medical Association Journal. 1982;126(6):657.

300. Barnouin J, Chassagne M, Bazin $S$, Boichard D. Management practices from questionnaire surveys in herds with very low somatic cell score through a national mastitis program in France. $J$ Dairy Sci. 2004;87(11):3989-99.

301. Barkema $H$, Van der Ploeg J, Schukken Y, Lam T, Benedictus G, Brand A. Management style and its association with bulk milk somatic cell count and incidence rate of clinical 
mastitis. J Dairy Sci. 1999;82(8):165563.

302. Barkema H, Schukken Y, Lam T, Beiboer M, Benedictus G, Brand A. Management practices associated with low, medium, and high somatic cell counts in bulk milk. J Dairy Sci. 1998;81(7):1917-27.

303. Dufour S, Fréchette A, Barkema $\mathrm{H}$, Mussell A, Scholl D. Invited review: Effect of udder health management practices on herd somatic cell count. $J$ Dairy Sci. 2011;94(2):563-79.

304. FAO. FAOSTAT. Reporte 2009 de la producción de alimentos. Disponible en: http://faostat.fao.org/site/339/default.asp x. Consulta Octubre 2011.

305. FSA. Food Standard Agency. Raw drinking milk and raw cream control requirements in the different countries of the UK. Disponible en: http://www.food.gov.uk/foodindustry/guid ancenotes/hygguid/rawmilkcream.

306. Real Milk. Comercio de la leche en EEUU. Disponible en: http://www.realmilk.com/where1.htm.

307. CDC. Leche cruda (sin pasteurizar). Disponible en: http://www.cdc.gov/spanish/especialesC DC/LecheCruda/.

308. Center for Food Safety and Applied Nutrition. Grade "A" pasteurized milk ordinance: 2001 revision. US Department of Health and Human Services, Food and Drug Administration, Center for Food Safety and Applied Nutrition; 2002. Disponible en: http://www.cfsan.fda.gov/ ear/pmo01.ht $\mathrm{ml}$.

309. Currier RW. Raw Milk and Human Gastrointestinal Disease: Problems Resulting from Legalized Sale of" Certified Raw Milk". J Public Health Policy. 1981;2(3):226-34.

310. Potter ME, BLASER MJ, SIKES RK, KAUFMANN AF, WELLS JOYG. Human Campylobacter infection associated with certified raw milk. Am J Epidemiol. 1983;117(4):475.

311. ICA. Boletín epidemiológico mensual de ocurrencias de enfermedades vesiculares $y$ otras enfermedades de declaración obligatoria. Colombia, 2011. Dirección Técnica de vigilancía epidemiológica, Subgerencia de protección animal.

312. Official Journal of the European Union Corrigendum to Regulation (EC) No 853/2004 of the European Parliament and of the Council of 29 April 2004 laying down specific hygiene rules for food of animal origin (Official Journal of the European Union L 139 of 30 April 2004).

313. Maillot E. Sale of raw milk in France. Euro Surveill. 1998;2(13). Disponible en: http://www.eurosurveillance.org/ViewArti cle.aspx?Articleld=1238.

314. Wisconsin Briefs from the Legislative Reference Bureau.Raw milk sales.2010. Disponible en: http://legis.wisconsin.gov//rb/pubs/wb/10 wb1.pdf.

315. CMR. Standards and sanitation requirements for grade a raw milk. Disponible en: http://www.mass.gov/agr/legal/docs/330CMR-27.00-Proposed-Raw-MilkRegulation.pdf. Consulta Agosto 2011. 316. Espinosa V, Rivera G, García L. Los canales y márgenes de comercialización de la leche cruda producida en sistema familiar (estudio de caso). Veterinaria México. 2008;39(1):1-16.

317. Enticott G. Risking the rural: nature, morality and the consumption of unpasteurised milk. J Rural Studies. 2003;19(4):411-24.

318. DuPuis E. Nature's perfect food: How milk became America's drink: NYU Press; 2002.

319. Block D. Public health, cooperatives, local regulation, and the development of modern milk policy: the 
Chicago milkshed, 1900-1940. J Historical Geography. 2009;35(1):12853.

320. Lupton D. Risk, Londres/Nueva York. Routledge; 1999.

321. Douglas M, Wildavsky A. Risk and culture: Univ. of California Press; 1983. 


\section{ANEXOS}

\section{Anexo 1. Medidas de Control y Requisitos de Algunos Países para la Comercialización de Leche Cruda para Consumo Humano}

\section{COMUNIDAD EUROPEA (312)}

Según la regulación 853 de 2004 de la Comunidad Europea durante la producción de leche cruda se debe garantizar el cumplimiento de los siguientes requisitos:

\subsection{Requisitos Sanitarios}

a) La leche cruda debe proceder de animales con las siguientes características:

- Que no muestren síntomas de enfermedades contagiosas transmisibles a los seres humanos a través de leche;

- Que se encuentren en buen estado de salud, es decir, que no presentan signos de enfermedad particularmente del aparato genital ni presenten flujo u otra sintomatología como enteritis (diarrea y fiebre), o inflamación de la ubre;

- Que no tengan heridas en la ubre las cuales puedan afectar la leche;

- Animales a los cuales se les ha administrado sustancias o productos autorizados y se ha conservado el periodo de retiro prescrito;

- a los que no se les ha administrados sustancias o productos no autorizados o que no han sido sometidos tratamiento ilegal de acuerdo con Directiva 96/23/CE

b) En relación a la brucelosis y tuberculosis, la leche cruda deberá proceder de:

- bovinos que procedan de un rebaño oficialmente libre de brucelosis y tuberculosis;

- hembras de otras especies (con predisposición de adquirir brucelosis y/o tuberculosis), inspeccionados periódicamente según el plan de control aprobado por las autoridades competentes.

\subsection{Higiene de las Explotaciones Lecheras}

a) Requisitos para los instalaciones y equipos

- Los equipos de ordeño y las instalaciones en que sea almacenada, manipulada o enfriada la leche deberás estar situados y construidos de manera que se limite el riesgo de contaminación de la leche.

- Las instalaciones destinadas al almacenamiento de la leche deberán estar protegidas contra alimañas, estar separados de las instalaciones donde se alojan los animales y, cuando sea necesario para cumplir con 
los requerimientos establecidos en el ítem b, deberán contar con los equipos de refrigeración adecuados.

- Las superficies de los equipos destinados a entrar en contacto con la leche (utensilios, recipientes, tanques, etc.) deberán ser de fácil limpieza y desinfección y ser de materiales lisos, lavables y no tóxicos. Deben mantenerse además en buen estado.

- Después del uso, dichas superficies deberán limpiarse y, en el caso que sea necesario, desinfectarse (mínimo una vez al día)

b) Higiene durante el ordeño, recolección y transporte

- El ordeño deberá llevarse a cabo de forma higiénica garantizando en particular que:

- Antes de iniciar el proceso los pezones, la ubre y las parte contiguas estén limpias

- La leche de cada animal sea chequeada en busca de anomalías organolépticas o fisicoquímicas por el ordeñador o por métodos que aseguren resultados similares. La leche que presente anomalías no debe ser destinada para el consumo humano

- La leche de animales que presenten signos clínicos de enfermedad en la ubre no debe ser destinada a consumo humano en concordancia con las instrucciones de un veterinario.

- La leche que provenga de animales sometidos a tratamientos médicos y que sea obtenida antes de que finalice el plazo de espera no deberá destinarse para consumo humano. Además, los animales que se encuentren en tratamiento deberán ser identificados.

- Los aplicadores sellados o los aerosoles podrán ser aplicados únicamente con autorización de la autoridad competente y se utilizaran de una manera que no transmita niveles inaceptables de residuos a la leche

- Inmediatamente después del ordeño, la leche deberá conservarse en un lugar limpio, construido y equipado para evitar la contaminación. Debe ser enfriada inmediatamente a no más de $8^{\circ} \mathrm{C}$ en el caso de la recolección diaria, y a no más de $6{ }^{\circ} \mathrm{C}$ si la recolección no es diaria.

c) Higiene del personal

- El personal encargado del ordeño y/o manipulación de la leche cruda deberá llevar ropa limpia y apropiada.

- El personal encargado del ordeño deberá mantener un alto grado de limpieza personal. Cerca del lugar del ordeño deben estar disponibles instalaciones adecuadas para el lavado de manos y brazos del personal encargado del ordeño y del manejo de la leche cruda.

\subsection{Criterios para la Leche Cruda}


- Los siguientes criterios se aplican a la leche cruda en espera del establecimiento de una legislación más específica sobre la calidad de la leche y los productos lácteos.

- Se deberá comprobar el cumplimiento de los siguientes dos ítems por medio de un número representativo de muestras de leche cruda recogidas en las explotaciones productoras de leche. Estos controles podrán ser llevados a cabo por:

- El operador de la empresa alimentaria que produzca la leche

- La empresa alimentaria de acopio de la leche

- Un grupo de operadores de empresas alimentarias

- En el contexto de un esquema de control nacional o regional

- Los operadores de empresas alimentarias deberán iniciar los procedimientos para garantizar que la leche cruda cumpla los siguientes criterios:

\begin{tabular}{l|l}
\hline Recuento en placa a $30{ }^{\circ} \mathrm{C}($ por $\mathrm{mL})$ & $\leq 100.000\left(^{*}\right)$ \\
Recuento de Células Somáticas (por $\mathrm{mL})$ & $\leq 400.000\left(^{* *}\right)$ \\
\hline
\end{tabular}

$\left(^{*}\right)$ Media geométrica durante un periodo de dos meses, con la menos dos muestras al mes

$\left({ }^{* \star}\right)$ Media geométrica durante un periodo de tres meses, con al menos una muestras por mes, a menos que la autoridad competente establezca otra metodología que tenga en cuenta las variaciones estacionales en los niveles de producción.

- Sin perjuicio de la Directiva 96/23/EC, los operadores de empresas alimentarias deberán iniciar procedimientos para garantizar que la leche cruda no se coloca en el mercado si:

- Contiene residuos de antibióticos en una cantidad que, en relación con cualquiera de las sustancias mencionadas en los anexos I y III del Reglamento (EEC) No. 2377/90, supera los niveles autorizados en virtud de los estipulado en dicho reglamento o

- El total combinado de residuos de sustancias antibióticas supera un valor máximo permitido.

- Cuando la leche cruda no cumpla con lo estipulado en los dos ítems anteriores, los operadores de la empresa deberán informar a la autoridad competente y adoptar medidas para corregir la situación.

Además, en el caso de la leche cruda destinada al consumo humano directo, el etiquetado del producto deberá incluir las palabras "LECHE CRUDA".

\section{FRANCIA}

La venta de leche cruda destinada al consumo humano está autorizada pero estrictamente controlada por una decisión del Ministerio de Agricultura de 1985 que establece diferentes niveles de restricciones (313). De esta manera, todos los responsables de la producción de leche cruda destinada al consumo humano están obligados a:

- Registrarse en los servicios veterinarios para la concesión de licencias 
- Declarar la ausencia de casos clínicos de fiebre Q, y poseer una licencia de salud, que especifica, entre otras, las siguientes condiciones:

- Ausencia Total de brucelosis y tuberculosis (prueba de tuberculina anual)

- Estrictas condiciones de higiene en relación con el equipo (infraestructura, almacenamiento de la leche), ganadería, buenas prácticas, enfriamiento de la leche, y limpieza y desinfección del material

- Registro de la salud e identificación individual del ganado

- Definir con precisión los métodos utilizados para el empacado de la leche (materiales, lugar, límite de tiempo)

- Rotular los recipientes con: fecha límite para el consumo, fecha de envasado más 3 días si se empacaron individualmente en la granja y día de producción más 48 horas en el caso de la distribución a granel en contenedores

- Inscribir un número de licencia de funcionamiento en el envase o en el recipiente (para facilitar la búsqueda)

- Verificar con las autoridades reguladoras la conformidad de la leche cruda en cuanto a los recuentos de células somáticas (indicativo de la salud de la ubre) y criterios tanto microbiológicos (Tabla 1) como químicos. Adicionalmente se analizan bacterias residuales, antibióticos o antifungicidas.

- Las condiciones de control de transporte y conservación de la leche $\left(4^{\circ} \mathrm{C}\right)$.

La leche cruda para consumo humano está incluida en la categoría de "alimentos que no han sido sometidos a tratamientos de descontaminación o son susceptibles a una nueva contaminación después del tratamiento". De conformidad con la recomendación del Consejo Superior de Higiene pública de France, en 1993 se prevé que Listeria monocytogenes debe estar ausente en el momento de la producción y no exceder el límite de 100 microorganismos por gramo en el momento del consumo.

Tabla 1. Criterios de calidad microbiológica de la leche cruda destinada al consumo humano

\begin{tabular}{|c|c|c|c|c|c|c|}
\hline $\begin{array}{c}\text { Designació } \\
n\end{array}$ & $\begin{array}{c}\text { Microorganismo } \\
\mathrm{s} \text { aeróbios } 30^{\circ} \mathrm{C} \\
\text { (por } \mathrm{ml} \text { ) }\end{array}$ & $\begin{array}{c}\text { Coliforme } \\
\text { s fecales } \\
\text { (por ml) }\end{array}$ & $\begin{array}{c}\text { Salmonell } \\
\text { a (en } 1000 \\
\mathrm{ml})\end{array}$ & $\begin{array}{c}\text { Estreptococo } \\
\text { s Beta } \\
\text { hemolíticos } \\
\text { (in } 0,1 \mathrm{ml} \text { ) }\end{array}$ & $\begin{array}{l}\text { Punto de } \\
\text { ebullició } \\
\text { n estable }\end{array}$ & $\begin{array}{c}\text { Acidez } \\
\text { (gramo } \\
\text { s de } \\
\text { acido } \\
\text { láctico) } \\
\text { por } \\
1.000 \\
\text { ml) }\end{array}$ \\
\hline $\begin{array}{l}\text { Día de } \\
\text { envasado** }\end{array}$ & $<90,000$ & $<100$ & Ausente & Ausente & $\sim$ & $\sim$ \\
\hline $\begin{array}{l}\text { Fecha de } \\
\text { vencimiento }\end{array}$ & $<300,000$ & $<100$ & Ausente & Ausente & Estable & $1.4-1$ \\
\hline
\end{tabular}

*Solo estreptococos betahemoliticos de los grupos $f$ Lancefield A, B, C, G y L

** En el día de la producción (no envasados ni embalados individualmente)

\section{INGLATERRA Y GALES}


Los controles actuales sobre la venta de leche cruda bovina con respecto a higiene y normas de etiquetado son (305):

a) La leche puede venderse directamente a los consumidores por las explotaciones de producción de leche registradas o a través de repartidores de leche (milk roundsmen). Las ventas a través de otros puntos han sido prohibidas desde 1985, aunque se permiten ventas del productor en los mercados de los agricultores;

b) Los animales deben proceder de un rebaño oficialmente libre de tuberculosis y brucelosis;

c) La producción, ordeño y la elaboración de productos lácteos, deben cumplir con normas de higiene;

d) La leche deberá llevar las advertencias de salud adecuadas; incluyendo que el producto no debe ser consumido por niños, mujeres embarazadas, ancianos ni personas enfermas

e) El cumplimiento de los ítems a) y d) sobre es supervisado por inspecciones dos veces por año;

f) La leche es muestreada y evaluada trimestralmente bajo el control del "Animal Health Dairy Hygiene" para vigilar el cumplimiento de las normas con respeto a los recuentos totales de bacterias y coliformes.

\section{ESTADOS UNIDOS:}

\subsection{Wisconsin}

En la legislación para la comercialización para la leche cruda en Wisconsin se incluyen las siguientes disposiciones (314):

- Los productores de leche que deseen vender la leche cruda deben estar registrados ante el DATCP (Department of Agriculture, Trade and Consumer Protection)

- La autorización de venta de leche cruda para el consumo humano termina el 31 de diciembre de 2011.

- Las ventas sólo pueden tener lugar en las granjas donde se produce la leche.

- A los agricultores se les prohíbe la publicidad de la disponibilidad de leche cruda

- Deberá especificarse la información relacionada con la posible presencia de microorganismos que causan enfermedades, que no es producto recomendado para ciertas personas y que no proporciona los beneficios de la pasteurización. Esta información también deberá estar en los envases

- Los agricultores no están exentos de responsabilidad civil.

- Los agricultores deberán llevar muestras diarias de la leche durante un período de tiempo, mantener los registros de cada venta, y evaluar la leche respecto a ciertos patógenos en laboratorios certificados por el DATCP 
- La licencia para vender leche cruda puede ser suspendida si se detectan agentes patógenos en dos de las cuatro muestras mensuales consecutivamente.

\subsection{Massachusetts}

Según los requerimientos sanitarios, la leche destinada para venta al por menor puede ser producida y manipulada conforme con los estándares químicos, bacteriológicos, de temperatura, y los requerimientos sanitarios descritos a continuación (315):

Tabla 2. Estándares químicos, bacteriológicos y de temperatura de la leche cruda destinada al consumo humano

\begin{tabular}{|c|l|}
\hline Temperatura & $\begin{array}{l}\text { Refrigeración a } 40^{\circ} \mathrm{F}\left(4,45{ }^{\circ} \mathrm{C}\right) \text { o menor en las dos horas } \\
\text { siguientes al ordeño, siempre y cuando la temperatura de mezcla } \\
\text { después de cada ordeño no supere los } 50^{\circ} \mathrm{F}\left(10^{\circ} \mathrm{C}\right)\end{array}$ \\
\hline Limites bacterianos & $<20.000 \mathrm{por} \mathrm{ml}$ \\
\hline Coliformes & $<10$ por $\mathrm{ml}$ \\
\hline \multirow{2}{*}{ Medicamentos } & $\begin{array}{l}\text { Halo }<16 \mathrm{~mm} \text { con Bacillus Sterothermophilus mediante el método } \\
\text { de ensayo de disco especificado por métodos aprobados por el } \\
\text { Departamento }\end{array}$ \\
\cline { 2 - 2 } & $\begin{array}{l}\text { Los productores de leche individual no pueden tener valores } \\
\text { superiores de residuos de medicamentos respecto a los niveles } \\
\text { permitidos en la edición más reciente del PMO }\end{array}$ \\
\hline Células somáticas & $<750.000$ por ml \\
\hline Crioscopia & $(-) 0.525^{\circ} \mathrm{C}$ a menos que se demuestre estar libre de agua añadida \\
\hline
\end{tabular}

Adicionalmente los siguientes requisitos aplican a la leche cruda para la venta al por menor.

- Leche contaminada: las animales que muestran evidencia de secreción de leche anormal en uno o más cuartos, basados en exámenes bacteriológicos, químicos o físicos, deberán ser ordeñadas al final de la jornada o con un equipo diferente, y la leche debe ser desechada. Los animales tratados con químicos o que han consumido productos químicos, medicinales o agentes radiactivos, los cuales pueden ser excretados en la leche, y que a juicio del organismo regulador pueda ser perjudicial para la salud humana, deberán ser ordeñadas al final de la jornada o con un equipo diferente y la leche deberá eliminada.

- Construcción la granja, establo o sala de ordeño: las áreas utilizadas para fines de ordeño deberá contar con:

- Pisos construidos en concreto o material impermeable, fácil de limpiar. Además puede existir un área ubicada la sala de ordeño en 
la cual están las vacas maternas y convalecientes, lo cual está sujeto a previa a aprobación del departamento competente

- Las paredes y el techo deben ser lisos, pintados o acabados de manera aprobada y deben estar en buen estado

- Áreas separadas de los corrales para caballos, terneros y toros

- Los porcinos y aves de corral se mantendrán fuera de la granja de ordeño

- La luz natural y/o artificial deberá estar bien distribuida durante el día y/o noche de ordeño

- Se debe evitar el hacinamiento

- Se deben tener cajas cubiertas, recipientes o instalaciones de almacenamiento separadas para la tierra, el picado y los concentrados.

- Limpieza del establo, granja o sala de ordeño: los pisos, paredes, techos, ventanas, tuberías y los equipos empleados deben mantenerse limpios.

- Corrales: los corales deben poder ser drenados para evitar el agua estancada y acumulaciones de residuos. El establo, la cama de los bovinos y el excremento deben ser limpiado con intervalos de frecuencia adecuados para evitar la contaminación de la ubre. El desperdicio de los alimentos no se deben acumular.

- Sala de ordeño: estas instalaciones deben contar con:

- Tamaño adecuado para facilitar el enfriamiento, la manipulación, el almacenamiento de la leche, la limpieza y desinfección, y el almacenamiento de los envases y los utensilios.

- Piso liso construido de concreto o material impermeable y en buen estado, adecuado para drenar. Los residuos líquidos deberán ser desechados de manera sanitaria; adicionalmente, los desagües deberán ser accesibles y estar conectados al sistema de alcantarillado sanitario.

- Las paredes y techos deberán ser construidos de material liso, estar en buen estado, bien pintados, o terminados de manera adecuada.

- La iluminación debe ser suficiente ya sea natural y/o artificial

- Debe haber buena ventilación

- Estas instalaciones no se deben usar con otro propósito, no habrá apertura directa en cualquier granja, establo o en una habitación de uso doméstico

- Se debe disponer de agua caliente y fría a presión

- Disponer de un tanque de enfriamiento de tamaño y profundidad suficiente $u$ otras instalaciones de refrigeración aprobadas

- Las instalaciones de refrigeración no se deben utilizar para ningún otro propósito diferente al de enfriamiento y almacenamiento de la leche, adicionalmente deberán estar protegidos de la contaminación y mantenerse en condiciones sanitarias.

- Granja lechera: 
- Los pisos, paredes, techos, ventanas, mesas, estanterías, armarios, tinas de lavado, superficies de contacto de los envases de leche, utensilios y equipo y equipo de la sala de ordeño deben estar limpias.

- En la sala de ordeño sólo debe haber artículos directamente relacionados con las actividades las actividades de ordeño, además debe estar libres de basura, animales y aves.

- Inodoro:

- Debe estar provisto de uno o más servicios, convenientemente ubicados, construidos y operados, y mantenerse en una manera higiénica. Los residuos deberán ser inaccesibles a las moscas y no contaminar la superficie del suelo o cualquier suministro de agua.

- Suministro de Agua:

- El agua para la lechería y las operaciones de ordeño deberá ser de una fuente de agua potable debidamente localizada, protegida y operada, además deberá ser fácilmente accesible, adecuada y de una calidad segura y sanitaria.

- Utensilios y equipos:

- Todos los envases de usos múltiples, equipos y utensilios utilizados en la manipulación, almacenamiento o transporte de la leche, deben ser en material liso, no absorbente, resistentes a la corrosión, no tóxicos, fáciles de limpiar y deben estar en buenas condiciones.

- Las superficies de contacto empleadas durante la manipulación, almacenamiento y transporte deben ser limpiadas y desinfectadas antes de cada uso

- Control de insectos y roedores.

- Deberán tomarse medidas eficaces para evitar la contaminación de la leche, recipientes, equipos y utensilios con insectos, roedores y por los productos químicos utilizados para control de plagas.

- El entorno se mantendrá ordenado, limpio, y libre de condiciones que podrían albergar o ser propicio para la cría de insectos y roedores.

Requerimientos adicionales para la comercialización de leche cruda:

Ninguna persona podrá vender, distribuir, proporcionar u ofrecer para el consumo al público la leche cruda en un lugar diferente a la granja lechera donde se produjo; además, la granja debe contar con un Certificado de Venta de Leche Cruda Para la Venta al por Menor emitido por el Comisionado. A los efectos de este Reglamento el término "oferta para el consumo" incluirá toma de muestras de leche por parte del público o la oferta de muestras al público.

Tabla 3. Requerimientos adicionales para el almacenamiento y los contenedores

\begin{tabular}{|l|l|}
\hline & $\begin{array}{l}\text { La leche debe estar almacenada en tanques autorizados o cantinas } \\
\text { de acero inoxidable. }\end{array}$ \\
Almacenamiento & $\begin{array}{l}\text { Todos los envases deberán ser almacenados a } 40^{\circ} \mathrm{F}\left(4,45^{\circ} \mathrm{C}\right) 0^{\circ} \\
\text { menos, en las instalaciones que han sido aprobadas por el } \\
\text { comisionado o su agente. }\end{array}$ \\
\hline
\end{tabular}




\begin{tabular}{|l|l|}
\hline & $\begin{array}{l}\text { Debe contar con una unidad de refrigeración comercial de un } \\
\text { material impermeable, suave y fácil de limpiar para almacenar la } \\
\text { leche cruda al por menor en envases; también está permitida una } \\
\text { nevera empleada en el hogar en buenas condiciones mecánicas y } \\
\text { físicas. }\end{array}$ \\
\hline - Todas las instalaciones deberán estar equipadas con un termómetro \\
graduado. \\
- Se prohíbe el uso de las instalaciones de almacenamiento húmedas \\
durante el manejo de contenedores
\end{tabular}




\section{Anexo 2. Breve Reseña de los aspectos sociales y culturales del consumo de leche cruda}

La producción, distribución y consumo de leche cruda para consumo humano directo, requiere ser analizada teniendo en cuenta diversos aspectos que incluyen aquellos del orden social y cultural, para lo cual el país requiere investigaciones que caractericen las dinámicas socioculturales a este comportamiento.

Teniendo en cuenta estudios realizados en otros países como México (316), Inglaterra (317) y Estados Unidos $(318,319)$ evidencia que el consumo de leche cruda manifiesta tensiones entre las formas tradicionales de producción, acopio, distribución y consumo y aquellas más modernas y altamente tecnificadas. Así mismo es posible afirmar que esta tensión se extiende a las formas de producción de pequeña escala frente a aquellas de gran e incluso mediana escala, en donde diversos determinantes sociales establecen mecanismos que no permiten que el productor de pequeña escala logre adaptarse a las reglamentaciones sanitarias y a los procesos de tecnificación que permiten mayor eficiencia y competitividad en el mercado.

Adicionalmente, el consumo de leche cruda también debe ser entendido, junto con los aspectos anteriormente mencionados, teniendo en cuenta su dimensión cultural e histórica. En este sentido, las formas tradicionales de distribución y consumo de leche cruda son el producto de la historia social de las poblaciones hecho que, además, determina la manera como los diversos actores de la cadena láctea valoran y dan significado a la leche cruda y establecen mecanismos de comercialización que les permiten continuar vigentes en el mercado actual. Es así como algunos estudios (Enticott,2003) (317) han demostrado cómo la leche cruda puede encarnar aspectos identitarios de las comunidades rurales donde el consumo de leche cruda es asociado al hecho del ser rural y por tanto de estar en contacto con lo natural. Para el caso de Colombia no se cuenta con estudios que exploren aspectos ya sea identitarios o políticos asociados al consumo de leche cruda que evidencien la manera como éstos impactan o determinan su distribución y consumo, ni que analicen cómo estos aspectos se comportan en cada región del país o en el marco de la relación ruralurbano.

Finalmente, otro aspecto social y cultural necesario para comprender el fenómeno del consumo de leche cruda está relacionado con las formas como los actores de la cadena dan sentido y perciben el riesgo, lo cual no necesariamente coincide con las formas como el saber científico define el riesgo. Las formas como las personas (ya sea productores, distribuidores o consumidores) dan sentido al riesgo son altamente complejas y están basadas en la manera en que estas conocen y se relacionan con su entorno $(320,321)$. En este sentido, la forma de valorar el riesgo desde el nivel de la vida cotidiana puede afectar cómo las personas evalúan y dan sentido a sus prácticas ya sea de producción, procesamiento y manipulación, distribución, preparación o consumo de la leche cruda. En Colombia, aún no se cuenta con estudios que exploren cuáles son las percepciones del riesgo frente al consumo de leche cruda ni cuál es el impacto de dichas percepciones en prácticas de riesgo.

Es posible concluir, teniendo en cuenta lo descrito anteriormente, que diversos aspectos aun quedan por explorar frente a la leche cruda tanto a nivel del país como a un nivel de menor escala (por regiones) y es por esto que los impactos sociales y culturales de la comercialización y consumo de leche cruda aún están por ser explorados y definidos para la toma de decisiones. 
